NATIONAL LABORATORY

\title{
Very High-Temperature Reactor (VHTR) Proliferation Resistance and Physical Protection (PR\&PP)
}

\section{August 2010}

Prepared by

David L. Moses

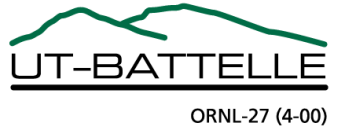




\section{DOCUMENT AVAILABILITY}

Reports produced after January 1, 1996, are generally available free via the U.S. Department of Energy (DOE) Information Bridge.

Web site http://www.osti.gov/bridge

Reports produced before January 1, 1996, may be purchased by members of the public from the following source.

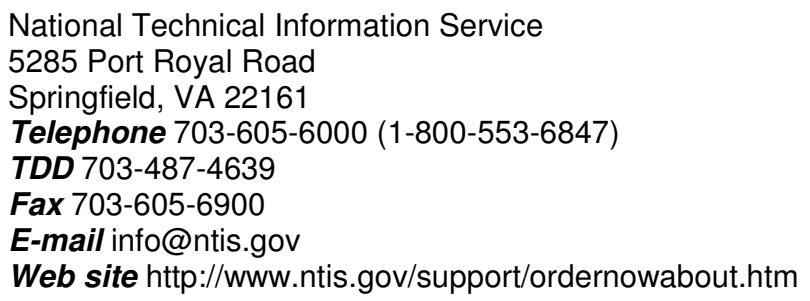

Reports are available to DOE employees, DOE contractors, Energy Technology Data Exchange (ETDE) representatives, and International Nuclear Information System (INIS) representatives from the following source.

Office of Scientific and Technical Information

P.O. Box 62

Oak Ridge, TN 37831

Telephone 865-576-8401

Fax 865-576-5728

E-mail reports@osti.gov

Web site http://www.osti.gov/contact.html

This report was prepared as an account of work sponsored by an agency of the United States Government. Neither the United States Government nor any agency thereof, nor any of their employees, makes any warranty, express or implied, or assumes any legal liability or responsibility for the accuracy, completeness, or usefulness of any information, apparatus, product, or process disclosed, or represents that its use would not infringe privately owned rights. Reference herein to any specific commercial product, process, or service by trade name, trademark, manufacturer, or otherwise, does not necessarily constitute or imply its endorsement, recommendation, or favoring by the United States Government or any agency thereof. The views and opinions of authors expressed herein do not necessarily state or reflect those of the United States Government or any agency thereof. 


\title{
VERY HIGH-TEMPERATURE REACTOR (VHTR) PROLIFERATION RESISTANCE AND PHYSICAL PROTECTION (PR\&PP)
}

\author{
David L. Moses
}

Date Published: August 2010

$$
\text { Prepared by }
$$

Oak Ridge, Tennessee 37831-6283 managed by for the U.S. DEPARTMENT OF ENERGY under contract DE-AC05-00OR22725 



\section{CONTENTS}

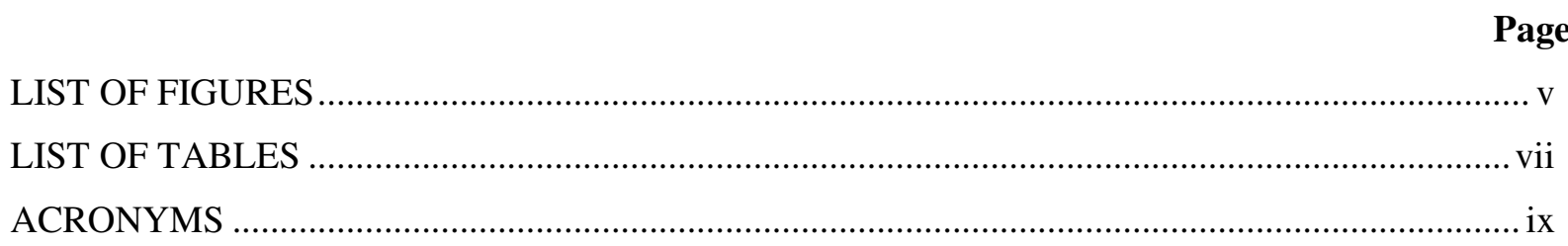

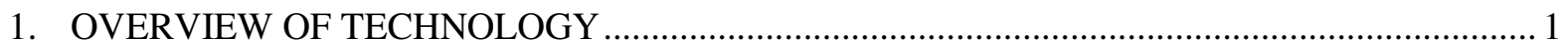

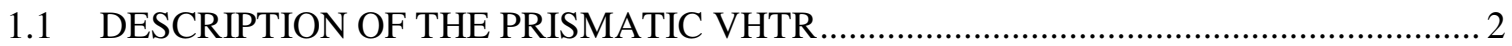

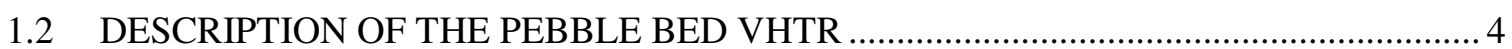

1.3 CURRENT SYSTEM DESIGN PARAMETERS AND DEVELOPMENT STATUS .......... 6

1.4 THE COMMON SAFETY BASES FOR THE VHTR CONCEPTS ................................... 6

1.5 TECHNICAL-BASIS COMPARISON FOR PRISMATIC AND PEBBLE BED

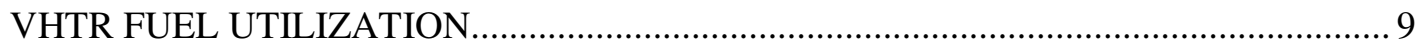

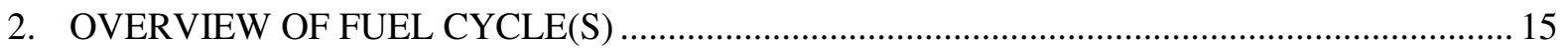

3. PR\&PP RELEVANT SYSTEM ELEMENTS AND POTENTIAL ADVERSARY

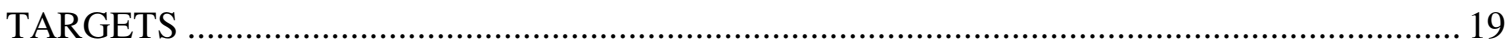

4. PROLIFERATION RESISTANCE CONSIDERATIONS INCORPORATED INTO

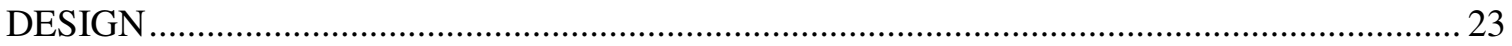

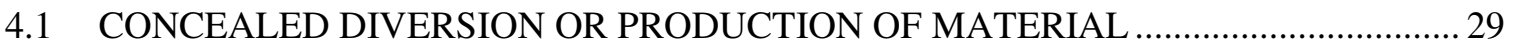

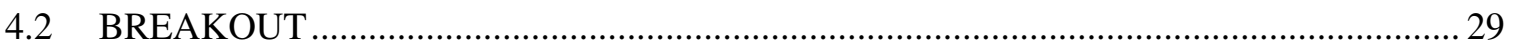

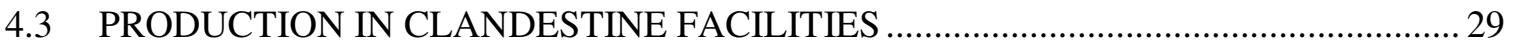

5. PHYSICAL PROTECTION CONSIDERATIONS INCORPORATED INTO DESIGN............. 31

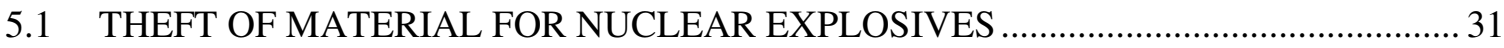

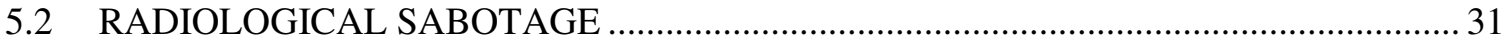

6. PR\&PP ISSUES, CONCERNS AND BENEFITS .............................................................. 33

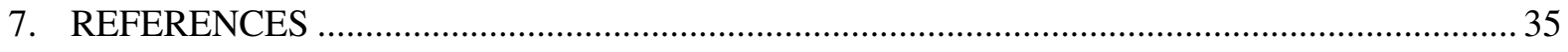

APPENDIX A VHTR MAJOR REACTOR DESIGN PARAMETERS ….................................. A-1

APPENDIX B A COMPARISON OF VHTR FUEL CYCLE PARAMETERS ........................... B-1

APPENDIX C TECHNICAL HISTORY REVIEW OF HTGR SPENT FUEL DISPOSAL, REPROCESSING, AND RECYCLE/REFABRICATION TECHNOLOGIES..... C-1 



\section{LIST OF FIGURES}

Figure

Page

1.1 Illustration of coated particle fuel in the prismatic fuel element …................................. 3

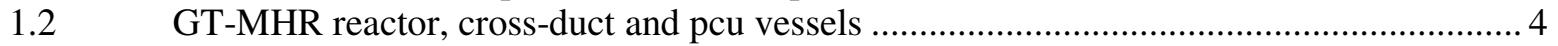

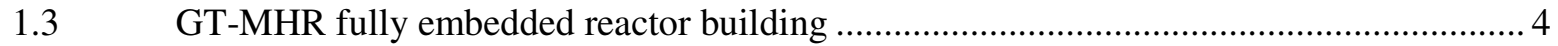

$1.4 \quad$ Illustration of coated particle fuel in pebble fuel element ............................................. 5

1.5 $400 \mathrm{MW}$-thermal PBMR partially embedded reactor building with reactor vessel

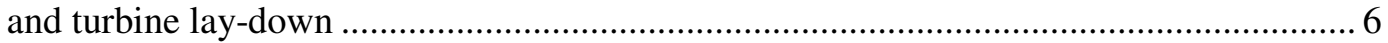

1.6 $250 \mathrm{MW}$-thermal HTR-PM reactor building elevated above ground level with

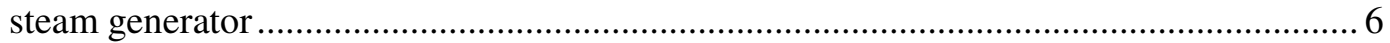

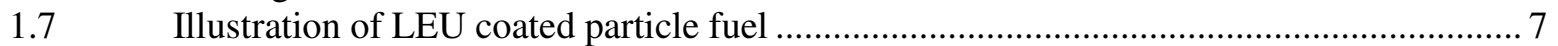

$1.8 \quad$ PBMR fuel loadings from non-fueled start-up to normal operation .............................. 11

$1.9 \quad$ PBMR core unloading and reloading during maintenance shutdowns ............................ 12

1.10 PBMR core discharge inventories (graphite, start-up fuel, and equilibrium fuel) as a function of recirculation timing ............................................................................... 12

1.11 Schematic of proposed IAEA support measures for the application of safeguards at

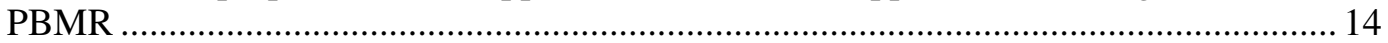

3.1 Diagram of VHTR nuclear system elements ............................................................ 19

4.1 Plutonium build-up in a PBMR fuel element in an equilibrium core ............................. 25

C.1 Later Dragon Reactor experiment (DRE) tubular fuel element designs_-annular

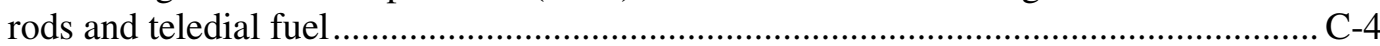





\section{LIST OF TABLES}

Table

Page

4.1 Calculated plutonium isotopic fractions for PBMR spent fuel as a function of initial enrichment and discharge burn-up............................................................................. 24

A.1 VHTR major reactor design parameters ............................................................. A-3

B.1 A comparison of VHTR fuel cycle parameters ........................................................ B-3 



\section{ACRONYMS}

$\mathrm{CoK}$

$\mathrm{C} / \mathrm{S}$

DOE

EGCR

GA

GIF

GT-MHR

HEU

HTGR

HTR

HTR-PM

HTR-TN

HTTR

IAEA

INPRO

JAEA

JAERI

KAERI

KI

LEU

LWR

MA

MHTGR

MIT

MOX

NHDD

NEA

NGNP

NMC\&A

NNSA

NTS

OECD

OKBM

PBMR

PRC

PR\&PP

RCCS

THTR

TRU

USNRC

USNRC-NRR

USNRC-RES

VHTR

VNIINM continuity of knowledge

containment and surveillance

U.S. Department of Energy

experimental gas-cooled reactor

General Atomics

Generation IV International Forum

gas-turbine modular helium-cooled reactor

highly enriched uranium

high-temperature gas-cooled reactor

modular high-temperature reactor

high-temperature reactor-pebble bed module

High-Temperature Reactor-Technology Network

high-temperature test reactor

International Atomic Energy Agency

International Project on Innovative Nuclear Reactors and Fuel Cycles

Japan Atomic Energy Agency

Japan Atomic Energy Research Institute

Korea Atomic Energy Research Institute

Kurchatov Institute

low-enriched uranium

light water reactor

minor actinide

modular high-temperature gas-cooled reactor

Massachusetts Institute of Technology

mixed oxide

Nuclear Hydrogen Development and Demonstration Project

Nuclear Energy Agency

next generation nuclear plant

nuclear material control and accountancy

National Nuclear Security Administration

Nevada Test Site

Organization for Economic Cooperation and Development

Experimental Design Bureau of Mechanical Engineering

pebble bed modular reactor

People's Republic of China

proliferation resistance and physical protection

Reactor Cavity Cooling System

thorium high-temperature reactor

transuranic

U.S. Nuclear Regulatory Commission

USNRC Office of Reactor Regulation

USNRC Office of Regulatory Research

very high-temperature reactor

A.A. Bochvar All-Russian Scientific Research Institute for Inorganic Materials 



\begin{abstract}
This report documents the detailed background information that has been compiled to support the preparation of a much shorter white paper on the design features and fuel cycles of Very HighTemperature Reactors (VHTRs), including the proposed Next-Generation Nuclear Plant (NGNP), to identify the important proliferation resistance and physical protection (PR\&PP) aspects of the proposed concepts. The shorter white paper derived from the information in this report was prepared for the Department of Energy Office of Nuclear Science and Technology for the Generation IV International Forum (GIF) VHTR Systems Steering Committee (SSC) as input to the GIF Proliferation Resistance and Physical Protection Working Group (PR\&PPWG) (http://www.gen4.org/Technology/horizontal/proliferation.htm). The short white paper was edited by the GIF VHTR SCC to address their concerns and thus may differ from the information presented in this supporting report. The GIF PR\&PPWG will use the derived white paper based on this report along with other white papers on the six alternative Generation IV design concepts (http://www.gen-

4.org/Technology/systems/index.htm) to employ an evaluation methodology that can be applied and will evolve from the earliest stages of design. This methodology will guide system designers, program policy makers, and external stakeholders in evaluating the response of each system, to determine each system's resistance to proliferation threats and robustness against sabotage and terrorism threats, and thereby guide future international cooperation on ensuring safeguards in the deployment of the Generation IV systems. The format and content of this report is that specified in a template prepared by the GIF PR\&PPWG. Other than the level of detail, the key exception to the specified template format is the addition of Appendix $\mathrm{C}$ to document the history and status of coatedparticle fuel reprocessing technologies, which fuel reprocessing technologies have yet to be deployed commercially and have only been demonstrated in testing at a laboratory scale.
\end{abstract}

\title{
1. OVERVIEW OF TECHNOLOGY
}

The Very High-Temperature Reactor (VHTR) design descriptions, technology overviews, and discussions of issues, concerns, and benefits documented in this report establish the bases to support more detailed assessments, as the designs evolve, using the methodology developed for evaluating the proliferation resistance and physical protection (PR\&PP) of the Generation IV reactors [1] with consideration of the International Atomic Energy Agency (IAEA) guidance for the application of an assessment methodology for innovative nuclear reactors and fuel cycles (INPRO) [2, 3].

Various versions of the VHTR are under development in several countries that are member states of the Generation IV International Forum (GIF), which includes the People's Republic of China, France, Japan, the Russian Federation, the Republic of South Africa, the Republic of Korea, and the United States of America. The VHTR is a helium-cooled, graphite-moderated, graphite-reflected, metallic-vessel reactor plant with the capability for the generation of electricity with possible cogeneration of process steam using a Brayton gas-turbine cycle, and high-temperature process heat for chemical process and hydrogen co-production. The major VHTR design options that potentially affect PR\&PP can be categorized as follows:

- Prismatic versus pebble fuel

- Direct versus indirect power conversion cycles

- Water versus air-cooled Reactor Cavity Cooling System (RCCS)

- Filtered confinement versus low leakage containment

- Below-grade embedment versus above-ground nuclear islands

The two VHTR basic design concepts considered here are the Prismatic VHTR and the Pebble Bed VHTR. 


\subsection{DESCRIPTION OF THE PRISMATIC VHTR}

There are currently five concepts for the prismatic VHTR under consideration by different GIF nations. The first two of the following have the generic features of low-enriched uranium (LEU) and plutonium-fuelled block-type cores and are sufficiently developed to be considered further here as examples for PR\&PP assessment. Except for the second concept discussed below, the prismatic VHTRs are being designed assuming the initial use of a once-though LEU fuel cycle.

- U.S.: The General Atomics (GA) prismatic-fuel, direct or indirect cycle, air-cooled RCCS, filtered confinement Gas-Turbine Modular Helium-cooled Reactor (GT-MHR) [4-10]. The GT-MHR is a $600 \mathrm{MW}$-thermal plant with options for cogeneration of electricity and process heat. ). In addition, GA has more recently proposed a less technically aggressive option by returning to consideration of the previously developed steam-cycle Standard Modular HighTemperature Gas-cooled Reactor (MHTGR) that was initially designed in the middle to late 1980s to operate at $350 \mathrm{MW}$-thermal and $140 \mathrm{MW}$-electric $[82,83]$. The completion of licensing-supporting research and development for the GT-MHR or the MHTGR is projected to take at least 10 years; the pace of progress in this effort is dependent upon the GT-MHR or the MHTGR being selected as a candidate for the DOE-funded Next Generation Nuclear Plant (NGNP).

- Russia: In cooperation with GA and the U.S. Department of Energy (DOE) National Nuclear Security Administration (NNSA), the Experimental Design Bureau of Mechanical Engineering (OKBM) in Nizhniy-Novgorod with partners at the Kurchatov Institute (KI) and the A.A. Bochvar All-Russian Scientific Research Institute for Inorganic Materials (VNIINM) in Moscow is designing a Russian version of the GA GT-MHR [9] to disposition excess weapon-grade plutonium; however, OKBM is also analyzing alternative fuel cycles for the Russian GT-MHR [11]. The deployment of the Russian GT-MHR is subject to DOE/NNSA joint funding to complete necessary research and development.

- France: The Areva prismatic-fuel, indirect cycle, water-cooled RCCS, filtered confinement Modular High-Temperature Reactor (HTR) (designated ANTARES) [12-18] where Areva is also partnered with other EURATOM participants in the High-Temperature ReactorTechnology Network (HTR-TN). The ANTARES Modular HTR is also envisioned to be a $600 \mathrm{MW}$-thermal cogeneration plant; however, the schedule for completion of research and development depends on end-user engagement.

- Japan: The Japan Atomic Energy Agency (JAEA) continues development work begun under the former Japan Atomic Energy Research Institute (JAERI) on the Gas Turbine High Temperature Reactor 300 for Cogeneration (GTHTR300C) [19, 20], which will scale up the technology from the JAEA 30 MW-thermal High Temperature Test Reactor (HTTR) [21] into a $600 \mathrm{MW}$-thermal configuration that shares design features with both the GA GT-MHR and the Areva Modular HTR except for being coupled to a horizontal turbine-generator for electricity production; however, deployment of the GTHTR300C is not envisioned until after 2030.

- South Korea: The Korea Atomic Energy Research Institute (KAERI) is pursuing the Nuclear Hydrogen Development and Demonstration (NHDD) Project; the NHDD reactor is to be limited to $200 \mathrm{MW}$-thermal (based on the maximum reactor vessel diameter, $6.5 \mathrm{~m}$, that can be fabricated in-country) with no decision yet made as to fuel/core type (pebble bed or prismatic), and the demonstration unit will not be completed for at least 15 years after ongoing research and development activities have been completed [22-24]. 
Technology summaries can be found for each vendor-proposed design option in the respective references provided above. The technical information on the point design of the Areva Modular HTR is more limited in detail compared to that available for the conceptual designs of the GT-MHR and the MHTGR, but both types of designs are built on the same base concept. These reactors are proposed to be constructed as modules with the Areva and GA designs to be built in sets of four or more modules per site. As indicated above, the baseline fuel design for the first modules uses LEU as TRISO-coated particle fuel in a once-through fuel cycle; the Russian version of the GT-MHR will use excess weapon plutonium as TRISO-coated fuel particles with the addition of erbium containing ${ }^{167} \mathrm{Er}$ to provide a neutron poison with a thermal neutron capture resonance to effect a negative moderator temperature coefficient of reactivity. The safety basis for all the prismatic VHTR is to design the reactor to achieve passive safety to avoid release of fission products under all conditions of normal operation and accidents including most beyond design basis events. This passive safety aspect of the design should make the VHTR less vulnerable to a significant risk of "radiological sabotage" through malevolent acts.

The TRISO-coated particle fuel (see Fig. 1.1) has a small-diameter (nominally 200-500 $\mu \mathrm{m}$ typically varying inversely with fissile inventory) spherical ceramic fuel kernel of either uranium oxide or uranium oxycarbide, or mixed oxides of other actinides. The kernel is coated with four coating layers consisting sequentially of low-density porous pyrocarbon, an inner high density pyrocarbon (IPyC), silicon carbide ( $\mathrm{SiC}),{ }^{*}$ and an outer high density pyrocarbon (OPyC). The coatings on the fuel particles serve as the primary containment preventing the release of fission products, and plant configurations and operating conditions are being designed appropriately to limit fuel temperatures during both normal operations and accident conditions so as to preclude the release of fission products. The coated particles are loaded into fuel compacts (sticks) held together by graphitized carbon. The fuel compacts are loaded into holes in hexagonal prismatic block fuel elements. Fuel elements are stacked in the reactor core with fissile and neutron burnable poison loadings tailored so that the power distribution is peaked toward the top of the core where the inlet cooling gas has the lowest temperature and the power density is lowest in the bottom of the core where the temperature of the outlet coolant is highest. The fuel and burnable poison loading patterns are set to keep the peak fuel temperature below the limit for normal operation, which is $1250^{\circ} \mathrm{C}$ for TRISO-coated fuel particles with SiC coatings.

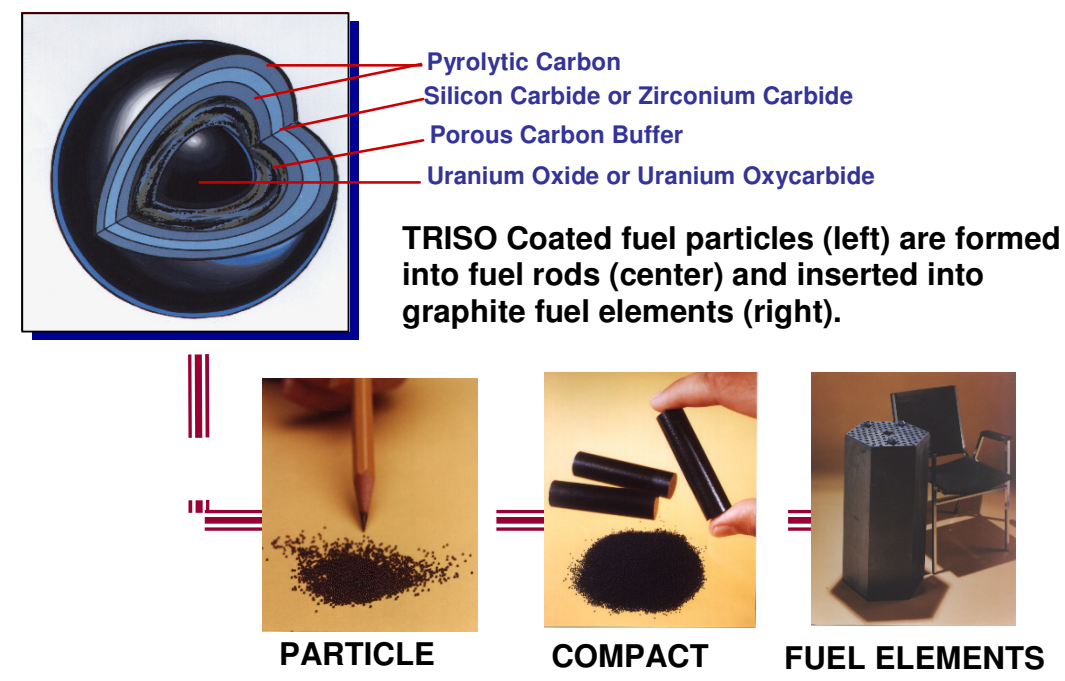

Fig. 1.1. Illustration of coated particle fuel in the prismatic fuel element.

\footnotetext{
*Ongoing research focuses on replacing $\mathrm{SiC}$ coatings with zirconium carbide $\mathrm{ZrC}$ ) coatings to achieve higher temperature limits $\left(2000^{\circ} \mathrm{C}\right)$ for fission product retention during accidents and to reduce diffusion of radioactive silver.
} 
Spent fuel is retained in cooled storage containers that are embedded below grade and located adjacent to the reactor cavity. Prismatic spent fuel, which is unloaded from the core during periodic refueling shutdowns, can be tracked remotely by cameras viewing the serial numbers on the fuel elements during handling and storage operations. Since each fuel element is loaded with less than 4 kilograms of LEU, the plutonium content at full burn-up ( 120 GWD/MT) will be small ( 60-70 grams) and isotopically degraded compared to weapon-grade plutonium.

The current concepts for the energy utilization from the prismatic VHTRs are based on the following:

- Direct Brayton cycle for electricity generation,

- Indirect steam generation for process heat and/or electricity generation,

- Indirect heat transfer to process heat user (e.g., hydrogen production) or to a secondary Brayton cycle.

The vessel configuration for the direct cycle GT-MHR is illustrated in Fig. 1.2, and the reactor building option for the GT-MHR is illustrated in Fig. 1.3. These illustrations for the GT-MHR layout are very similar to those for the earlier steam-cycle MHTGR upon which the GT-MHR below-grade embedded configuration is based.

For the GT-MHR or MHTGR, the reactor vessel and power conversion unit are placed subsurface, which improves and enhances the physical protection of the plant.

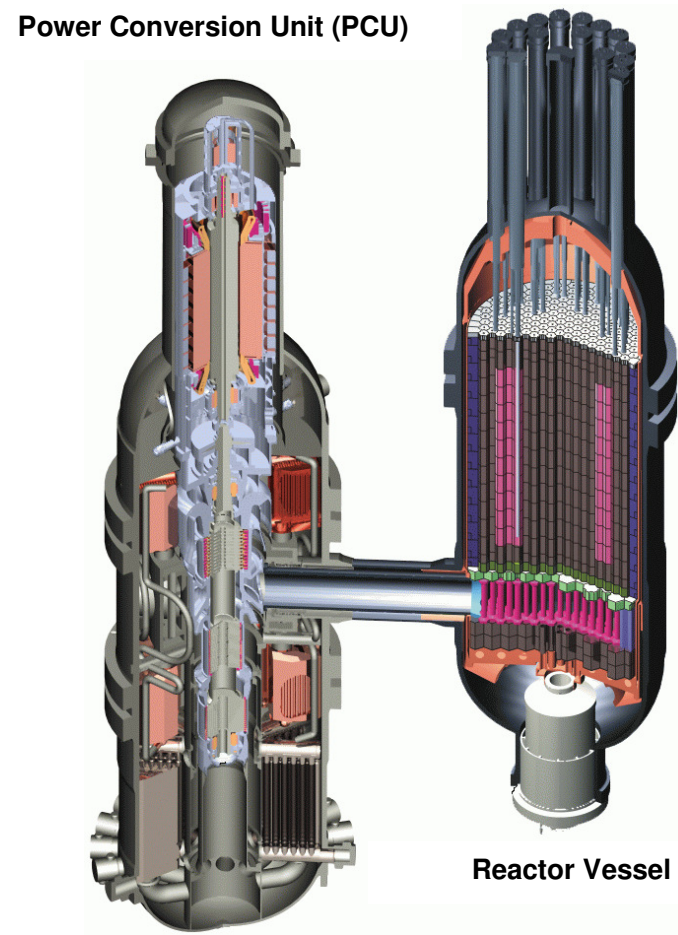

Fig. 1.2. GT-MHR reactor, cross-duct and pcu vessels.

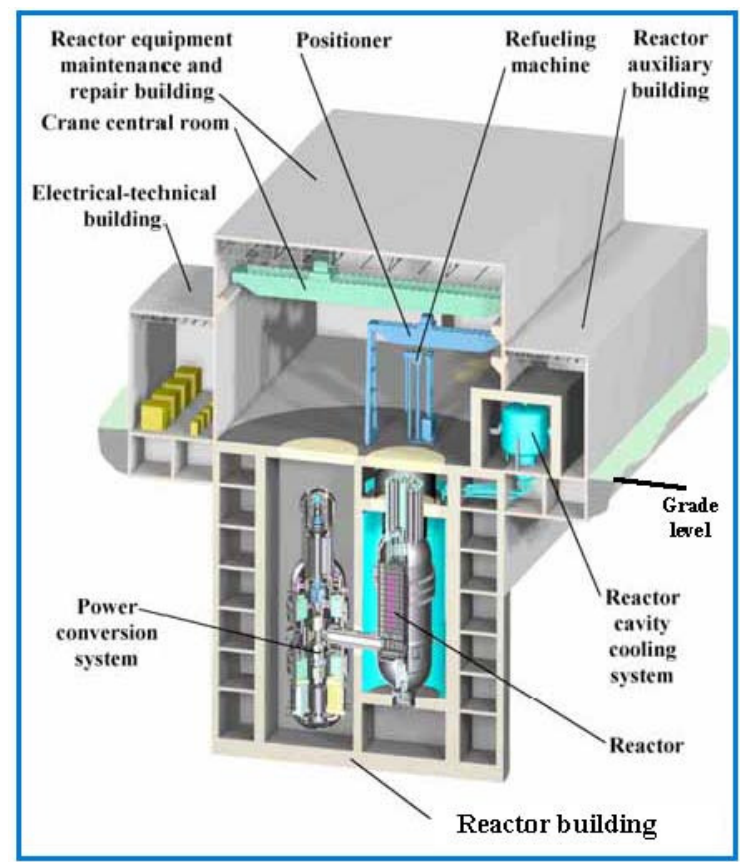

Fig. 1.3. GT-MHR fully embedded reactor building.

\subsection{DESCRIPTION OF THE PEBBLE BED VHTR}

In addition to the South Korea NHDD Project for which a fuel element design decision (prismatic or pebble bed) has not been made, there are two national programs for a pebble bed VHTR. 
- South Africa: The Westinghouse and South African PBMR (Pty) Ltd. pebble-fuel, watercooled RCCS, filtered confinement Pebble Bed Modular Reactor (PBMR) [10, 25-29] that has been being designed as a $400 \mathrm{MW}$-thermal direct Brayton cycle plant as an NGNP candidate but has recently been scaled back to a 200-250 MW-thermal steam cycle plant with a $200 \mathrm{MW}$-thermal, $80 \mathrm{MW}$-electric demonstration plant at Koeberg in South Africa planned to be commissioned in 2018. The core for the $400 \mathrm{MW}$-thermal PBMR was to be annular with an inner reflector of prismatic graphite reflector elements; the 200-250 MW-thermal core design would be cylindrical.

- People's Republic of China (PRC): The China Huaneng Group in a consortium with the China Nuclear Engineering \& Construction Group (CNEC) and Tsinghua University's Institute of Nuclear and New Energy Technology (INET) is developing and preparing nearterm (starting in 2009, commissioning in 2013) construction of the $250 \mathrm{MW}$-thermal, steamcycle High-Temperature Reactor-Pebble-bed Module (HTR-PM) [30, 31]; the HTR-PM, which builds on the success of the Tsinghua University's HTR-10 test reactor [32], is envisioned to be constructed in two module units producing $500 \mathrm{MW}$-thermal and $200 \mathrm{MW}$ electric. The HTR-PM core is to be cylindrical. The reactor vessel is placed above grade level, but the fuel handling system is situated below, underground.

The pebble bed reactors share the same passive safety features as the prismatic VHTRs but have less excess reactivity due to on-load refueling. The LEU fuel for the pebble bed VHTRs is to be TRISO-coated particles compacted in small spheres as illustrated in Fig. 1.4.

The pebble fuel is not tracked individually by serial number as in the prismatic core, but elements are counted, characterized, and checked following each of multiple recirculations until they achieve the target burn-up based on radioactivity measurements. Following several (about six) passes of each pebble through the core during on-line pebble recirculation, when pebble radioactivity indicates sufficient burn-up, the pebble is transferred to a storage container with a record kept of the number of pebbles transferred. Once pebble spent fuel is in the storage container, radiation monitoring is used to quantify by inference the amount of spent fuel present since, with no more than 0.12 grams of plutonium per pebble, it would take several tens of thousands of pebbles (or several metric tons by total mass and cubic meters by volume) to be diverted to constitute the basis for recovering a

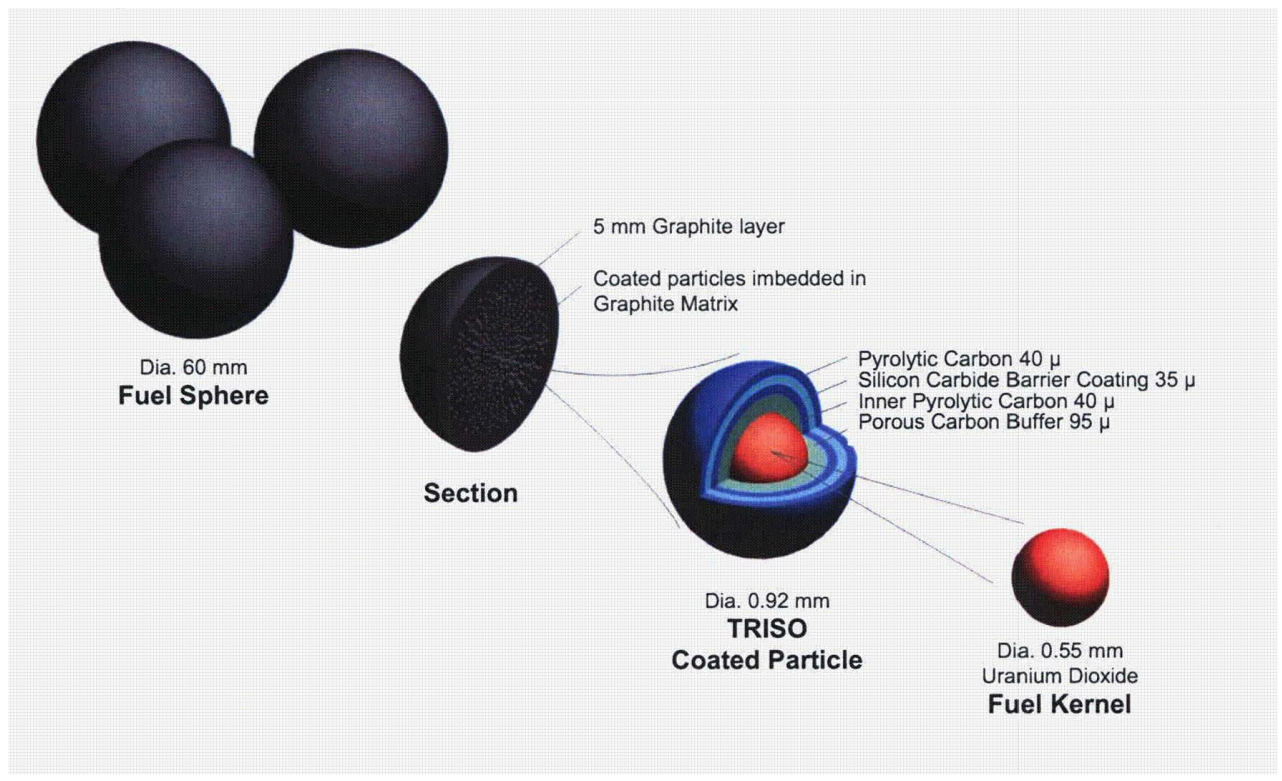

Fig. 1.4. Illustration of coated particle fuel in pebble fuel element. 
significant quantity of direct-use plutonium (8 kilograms) since a fresh PBMR pebble only contains 9 grams of LEU and a fresh HTR-PM pebble 7 grams. Further, at a burn-up around 90 GWD/MT, the plutonium isotopic composition in the pebble spent fuel is degraded significantly from that of weapon-grade plutonium.

The reactor building and vessel arrangement for the $400 \mathrm{MW}$-thermal Brayton-cycle PBMR concept is illustrated in Fig. 1.5 showing the partially embedded reactor with the horizontal gasturbine to the right of the reactor vessel and the associated spent fuel storage locations below-grade to the left of the reactor vessel. The reactor vessel and vessel arrangement for the $250 \mathrm{MW}$-thermal steam-cycle PRC HTR-PM is illustrated in Fig. 1.6 with the steam generator below and to the left of the reactor vessel but without indicating the location of spent fuel storage that is understood to be below grade.

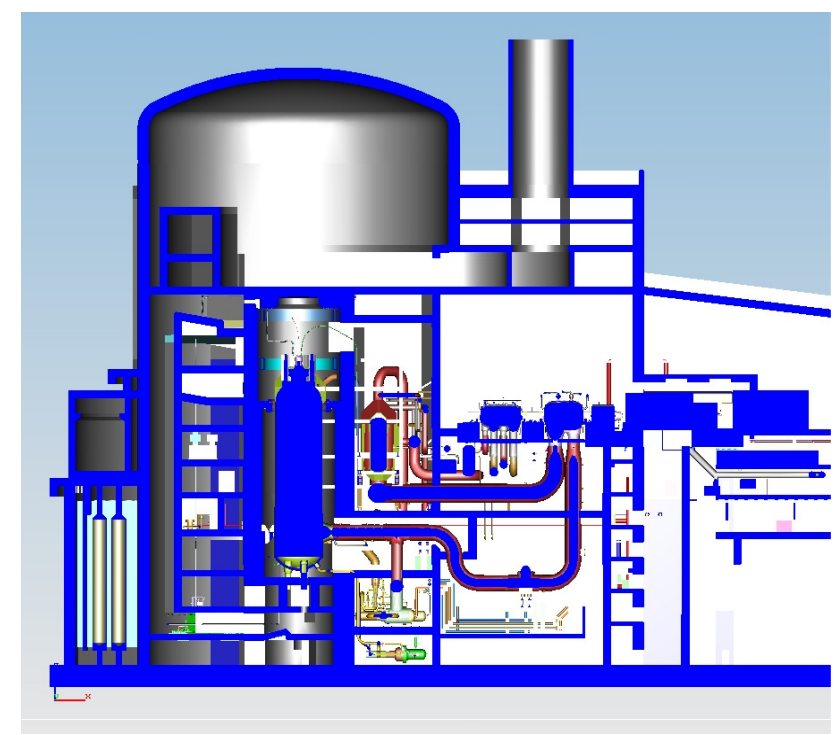

Fig. 1.5. 400 MW-thermal PBMR partially embedded reactor building with reactor vessel and turbine lay-down.

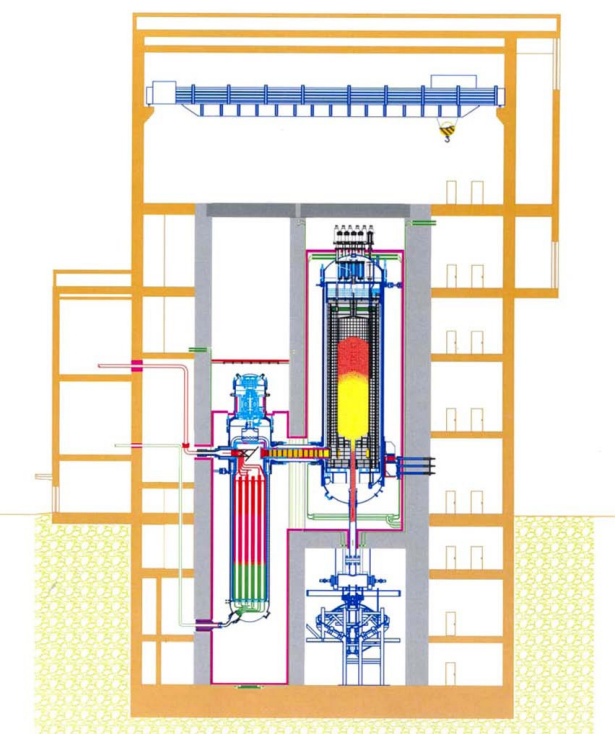

Fig. 1.6. $250 \mathrm{MW}$-thermal HTR-PM reactor building elevated above ground level with steam generator.

\subsection{CURRENT SYSTEM DESIGN PARAMETERS AND DEVELOPMENT STATUS}

The key design parameters for each concept (both prismatic and pebble bed) are presented in Appendix A. Since the South African design for the 200-250 MW-thermal steam-cycle PBMR has not yet been formulated, it is assumed that the PRC HTR-PM brackets this design. The site for the construction is already prepared. The HTR-PM is scheduled to start in 2010 with completion and commissioning in 2014. All other concepts require further development and are at least 10 years in the future. Completion of the necessary research and development for the potential NGNP candidates (GT-MHR, MHTGR, ANTARES Modular HTR, and 200-500 MW-thermal pebble bed designs) depends upon their selection for further funding by the U.S. government.

\subsection{THE COMMON SAFETY BASES FOR THE VHTR CONCEPTS}

As indicated previously, the common safety basis for both the prismatic and pebble-bed VHTR is to design the reactor to achieve passive safety to avoid release of fission products under all conditions of normal operation and accidents including beyond design basis events. This passive safety aspect of the design should make the VHTR less vulnerable to a significant risk of "radiological sabotage" through malevolent acts. This objective is to be achieved by the following. 
- Using ceramic coated fuel particles (see Fig. 1.7) where the coatings retain fission products as the primary containment as long as (1) the quality of the fuel fabrication process does not result in failed or externally contaminated particles, (2) the temperature of the particle is kept below certain limits at power and under non-power accident conditions with a core heat-up due to loss of forced cooling, and (3) chemical attack is avoided by preventing or limiting the ingress of water, air, or other corrosive chemicals from entering the core.

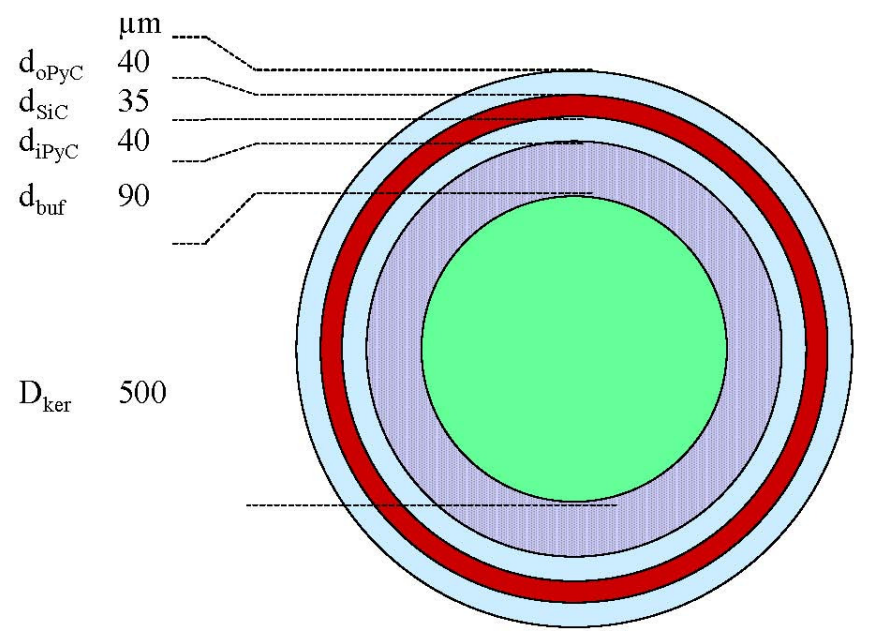

Fig. 1.7. Illustration of LEU coated particle fuel.

- Using a high-temperature, high-heat-capacity all ceramic core (graphite and graphitized carbon) and an inert single-phase coolant (helium gas).

- Limiting the thermal power and sizing the core and reactor vessel to allow for passive cooling by conduction, natural convection, and thermal radiation during loss of forced cooling events including depressurization of the primacy coolant loop, so the fuel temperature and time at temperature do not exceed the limits at which coated particle containment integrity is compromised.

- Providing for redundant decay heat removal capability with a non-safety-related active safeshutdown cooling system employing an in-vessel circulator and heat exchanger and with a safety-related passive RCCS to remove heat from the reactor (pressurized or depressurized) when active systems fail, including the capacity to reject heat to the building structure if the external heat sink is completely disrupted.

- Embedding at least part, if not all, of the reactor systems and spent fuel storage systems below grade (e.g., GT-MHR, MHTGR and Areva HTR) and hardening the above-grade portion sufficiently (e.g., PBMR) to resist penetration to eliminate or minimize the effects of adverse weather, seismic events, aircraft crashes, and possible terrorist attacks.

- Employing a fuel design with a sufficiently negative temperature coefficient of reactivity such that the reactor shuts down without requiring actuation of the reactivity control system upon loss of forced cooling.

- Employing a reactivity control system that limits the possible rate of positive reactivity insertion while ensuring adequate diverse and redundant means to achieve both hot and cold shutdown during an accident. 
- Designing to minimize the required actions by the operators in ensuring plant safety under all conditions.

To support the worldwide regulatory assurance for safety and safeguards in both the design and operation of the NGNPs and associated fuel cycle facilities, including for the VHTR, the IAEA has issued both Safety Standards (http://www-ns.iaea.org/standards/) and international regulatory requirements (based on compliance with international treaties and conventions) in the series of IAEA Information Circulars (http://www.iaea.org/Publications/Documents/Infcircs/index.html). The IAEA has also compiled detailed technical information on gas-cooled reactors in the HTGR Knowledge Base (http://www.iaea.org/inisnkm/nkm/aws/htgr/), which includes full-text retrievable documentation from IAEA-sponsored conferences, technical committee and specialists meetings, coordinated research projects, and technology reviews.

In addition to and often in collaboration with the IAEA, the Nuclear Energy Agency (NEA) (http://www.nea.fr/), which is a specialized agency within the Organization for Economic Cooperation and Development (OECD) and serves as the Secretariat for the GIF, provides guidance on nuclear safety and regulation with documentation retrievable from the NEA web site. The NEA, sometimes with co-sponsorship of the IAEA, has sponsored workshops on Advanced Reactors with Innovative Fuels (1998, 2001, 2005, and 2008) and Advanced Reactor Nuclear Safety and Research Needs (2002) and Information Exchange Meetings on Basic Studies in the Field of High-Temperature Engineering $(1999,2001,2003)$ wherein various HTR topics have been addressed. The proceedings of the NEA workshops and information exchange meetings may be found either on the NEA web site or, as read-only files retrievable by title, on Google Book Search (http://books.google.com/).

The USNRC has performed an expert review of the generic, pre-conceptual design of the VHTR to assess the potential challenges to fission product retention during normal operations and accidents and has documented the results in a series of contractor reports using Phenomena Identification and Ranking Tables (PIRTs) [33, 34]. These PIRTs supplement the previous USNRC findings from preapplication licensing reviews of the lower-power, steam-cycle GA MHTGR with two versions of the USNRC findings including that published initially by the USNRC Office of Regulatory Research (USNRC-RES) [35] and a later, somewhat less-consistent version published by the USNRC Office of Nuclear Reactor Regulation (USNRC-NRR) [36]. In addition, the USNRC-RES has sponsored a contractor review of the technology gaps that are recommended to be filled to satisfy safety and licensing requirements for the NGNP [37] focusing on safety in reactor design, operations and performance. Based on these initial assessments by the USNRC, the challenges to VHTR plant safety are judged to be sufficiently defined at this stage of the design for consideration in initially assessing the susceptibility to "radiological sabotage."

Assuming that the quality of fuel fabrication is such that the coated particles have acceptably low levels of defects in the particle coatings as well as low levels of heavy-metal fuel material contamination outside the coatings, the primary challenge to fuel element integrity for purposes of fission product retention is the temperature and time at temperature of the $\mathrm{SiC}$, or $\mathrm{ZrC}$, coatings on the fuel particle. As noted above, the VHTR systems are being designed to limit fuel temperatures under all plant conditions including accidents. The secondary challenge to fission product retention, aside from quality control in fuel fabrication, is from chemical attack of the fuel particle coatings. Water ingress has been the principal cause of chemical attack in the previous operation of hightemperature gas-cooled reactors (HTGRs) that used steam generators in the power conversion system with higher-pressure water-steam on the secondary side than the helium on the primary side. In the case of the steam-cycle Fort St. Vrain HTGR, the use of water-lubricated helium circulator bearings was the major source of water ingress.

For the VHTRs operating in electricity generation only, the high-pressure helium used for the direct Brayton cycle will preclude water or chemical ingress except for depressurized shutdowns such as for refueling or maintenance of primary-system components. For operations with an intermediate heat exchanger to a secondary working fluid for either electricity generation or process heat usage, 
the chemical composition and relative pressure of the secondary system fluid will determine the propensity for chemical ingress into the primary system in the event of a heat exchanger leak. The use of helium, a helium-nitrogen gas mixture, or a liquid salt secondary fluid does not pose significant concern for ingress and chemical attack on the fuel unless the fluid in the secondary system becomes chemically contaminated or degraded during operation. Depressurized shutdown is the most likely mode for the ingress of water or other chemicals into the primary system to cause chemical attack so the moisture and helium contamination detection systems on the primary coolant and the helium purification system are crucial to identifying leaks and providing for the mitigation or prevention of chemical attack before the reactor returns to full power and operating temperatures.

\subsection{TECHNICAL-BASIS COMPARISON FOR PRISMATIC AND PEBBLE BED VHTR FUEL UTILIZATION}

Both the prismatic core and pebble bed core fuel VHTRs share a common technical basis for the way in which the reactors are fueled and cooled. This basis is to maintain the fuel peak temperature below a normal operating limit, which for SiC-coated TRISO particles is usually accepted to be $1250^{\circ} \mathrm{C}$. To achieve meeting this limit, the fuel distribution is zoned by one or more means to have the axial power peaked near the core coolant inlet so that the highest power is produced where the helium coolant is at or near its lowest temperature. The fuel zoning is achieved much differently between the prismatic core reactors that are subject to periodic shutdowns for fuel shuffling and refueling and the pebble bed reactors that are subject to continuous on-line refueling and the recycling of previously irradiated and discharged fuel pebbles that have not achieved full burn-up and been discarded to spent fuel storage. Currently, all the VHTRs are conceived as being down flow cores so that the power distribution is peaked or the power density is highest at the top of the core. For both VHTR types on the LEU fuel cycle, attention is given by the reactor physics analysts to the distribution of LEU burn-up and the build-up of plutonium and their combined effects on the stability of the core to xenon-135 oscillations that could cause power flipping leading to the highest power being produced at or near the coolant outlet temperature that in turn could lead to exceeding the peak fuel temperature during normal operation.

Maintaining the axial power profile during power operation is made somewhat more difficult for the prismatic cores by the need to withdraw control rods from the bottom of the outer reflector surrounding the core either in a bank or by groups which will tend to push the power distribution down so that forcing the desired top-peaked power distribution requires attention to the axial fuel and poison zoning in the stack of fuel elements. Since azimuthally not all columns of prismatic fuel elements may be located adjacent to a withdrawing control rod in the outer reflector, in some cases, radial and/or azimuthal power flattening may be required using fuel and poison zoning. For the prismatic cores, these needs may vary from one core to another even for the same VHTR design. Since approximately half of the fuel is replaced at each reload in the equilibrium cycle of the GT-MHR or MHTGR, a once-burned fuel element will have a burn-up of between 60 and $70 \mathrm{GWD} / \mathrm{MT}$ on average but depending also upon where the fuel was located in the core with elements in the bottom of the core having a lower burn-up and those from the top of the core having a higher burn-up due to the power distribution management scheme.

In the pebble bed core, control rods will be withdrawn almost fully so that criticality, power levels, and radial/azimuthal power distributions maintained during prolonged constant-power operation will be accomplished by the on-line refueling scheme mixing fresh and irradiatedrecirculated fuel pebbles and controlling their insertion location into the top of the core.

For the designers of the prismatic cores, maintaining the desired axial, radial and azimuthal power distributions has several options that include the following.

- Varying the loading of fuel elements so that the higher fissile-loaded fuel elements are placed at the top of the core (and/or adjacent to control rods) while the lower fissile-loaded and/or 
higher fertile-loaded fuel elements are placed at the bottom of the core (and/or away from control rods) with perhaps some appropriate variation in fissile-loading for fuel elements in the middle of the core. For single particle cores with only fissile particles of a single enrichment (Modular HTR on LEU or the GT-MHR on weapon plutonium for deep-burn), fuel compacts in the fuel elements will vary the fissile content in the fuel compact by using inert graphite shim particles to reduce the loading of the fuel compact and therefore the fuel element. In two particle fissile-fertile cores (GT-MHR or MHTGR on LEU), either use of inert graphite shim particles to dilute the fissile loading or use of a combination of shim and fertile particles will allow the variation of fuel compact and fuel element fissile loadings, but the use of higher fertile loadings may impact the effect of plutonium production on late-incycle xenon-135 stability so the analysis of loading requirements has to consider all times in cycle life. Fuel loading variations may also be required to flatten radial or azimuthal power distributions but perhaps not at all elevations of the core such as only for fuel elements at the top of the core where the local power densities are highest so as to reduce coolant temperature entering the lower fuel elements.

- Using lumped or integral burnable poisons such as boron carbide $\left(\mathrm{B}_{4} \mathrm{C}\right)$ for lumped burnable poisons inserted into non-fuel holes (six per element in the GT-MHR or MHTGR on LEU) in some of the graphite fuel elements or erbium as an integral burnable absorber in the fuel particle or compact for the very high fissile/no-fertile content (deep burn) fuels, where the thermal capture resonance of erbium-167 assists in keeping the sign of the moderator temperature coefficient of reactivity negative. Lumped burnable poisons may also be required at times to flatten the radial and azimuthal power distributions.

- Reloading or shuffling irradiated fuel elements either azimuthally or axially to control the axial, radial and azimuthal power distributions.

Therefore, as a result of loading each fuel element or groupings of fuel elements uniquely to control power distributions in the VHTR prismatic cores, each serial-numbered fuel element will have to be tracked separately as to initial loading, in-core locations during irradiation cycles, and burn-up both for the reactor physics analyses of power distributions to support demonstrating that the peak fuel temperature limits are not exceeded during normal operation and for nuclear material control and accountancy (NMC\&A) records for spent fuel placed in storage after discharge. This NMC\&A tracking is similar to that of serial-numbered pressurized water reactor (PWR) subassemblies except that it is made more complicated by axial fuel zoning in the prismatic VHTRs and by the large number of separate items to track (1020 in the GT-MHR, 660 in the MHTGR, during any one cycle with half of the core reloaded after each cycle versus typically $\lesssim 200$ in any one PWR cycle with between one-half to one-third of the core reloaded after each cycle). By comparison, the LEU loading in a prismatic VHTR fuel element is on the order of 3-4 kilograms in each element with a total element mass of $\sim 122$ kilograms [Table 3-4 in Refs. 5 and 6] while a typical PWR subassembly will have 450 kilograms of LEU in a subassembly having a mass of between 650 and 750 kilograms and obviously will also have proportionately higher plutonium loadings at discharge after burn-up.

The control of power distributions in the PBMR can best be explained in the context of the illustrations in Figs. 2 through 7 in Ref. 28 and in slides 36 through 45 of the presentation on "PBMR Reactor Unit and Main Support Systems" in Ref. 27 (see Figs. 1.8, 1.9, and 1.10). To summarize these illustrations, the initial loading of the PBMR is totally with non-fuel graphite pebbles to check core flow and pressure drop at zero power. The graphite pebbles are then unloaded gradually from the bottom of the core and replaced at the top of the core with the initial core fuel pebbles ( 9 grams of LEU per pebble at an estimated $\sim 5.7$ percent enrichment) before control rods are withdrawn to approach criticality. Initial criticality is achieved [Fig. 2 in Ref. 28 or first quadrant in Fig. 1.8] with the graphite pebbles essentially forming a lower reflector in the bottom half of the core. Approach to 


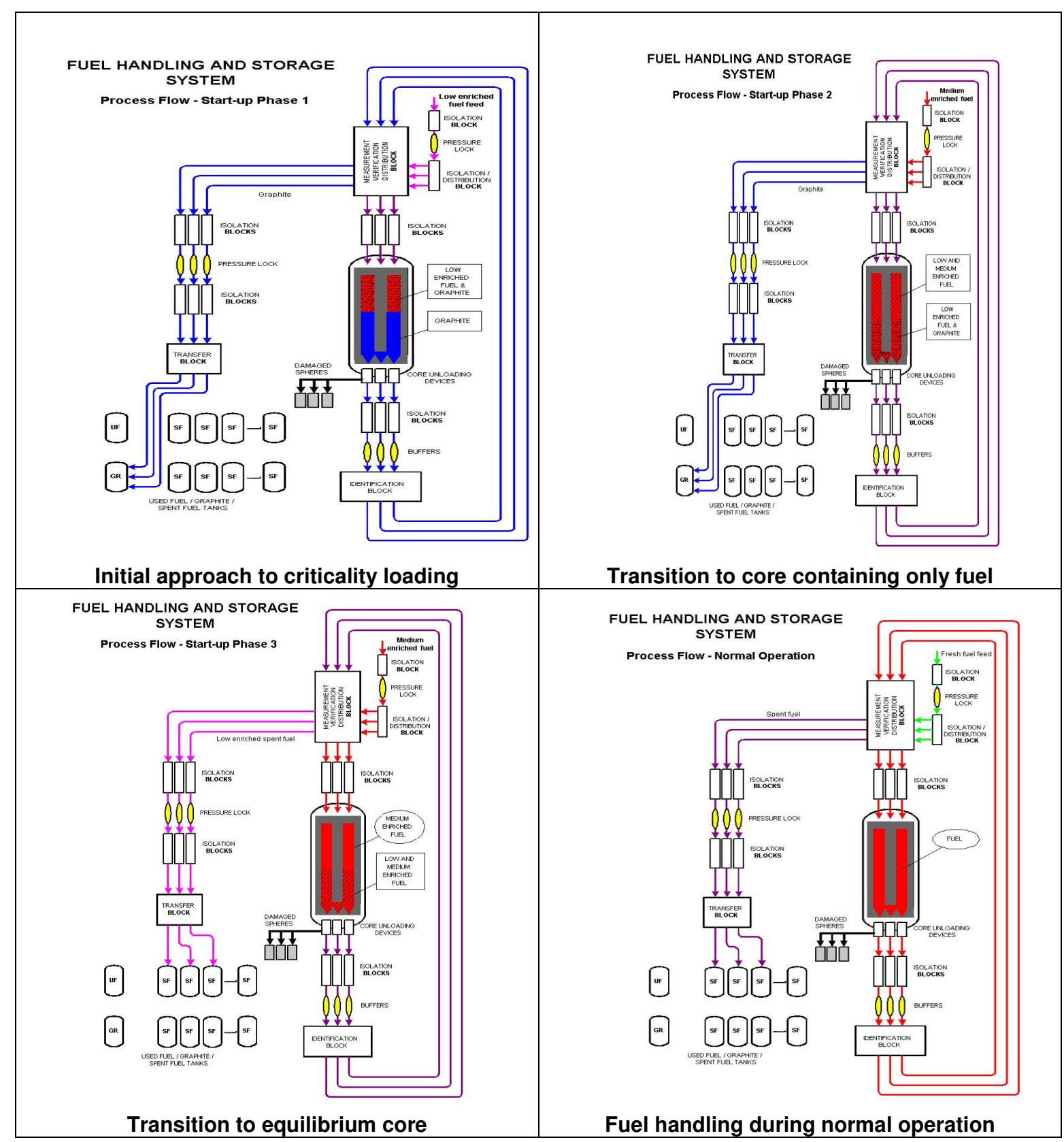

Fig. 1.8. PBMR fuel loadings from non-fueled start-up to normal operation. 


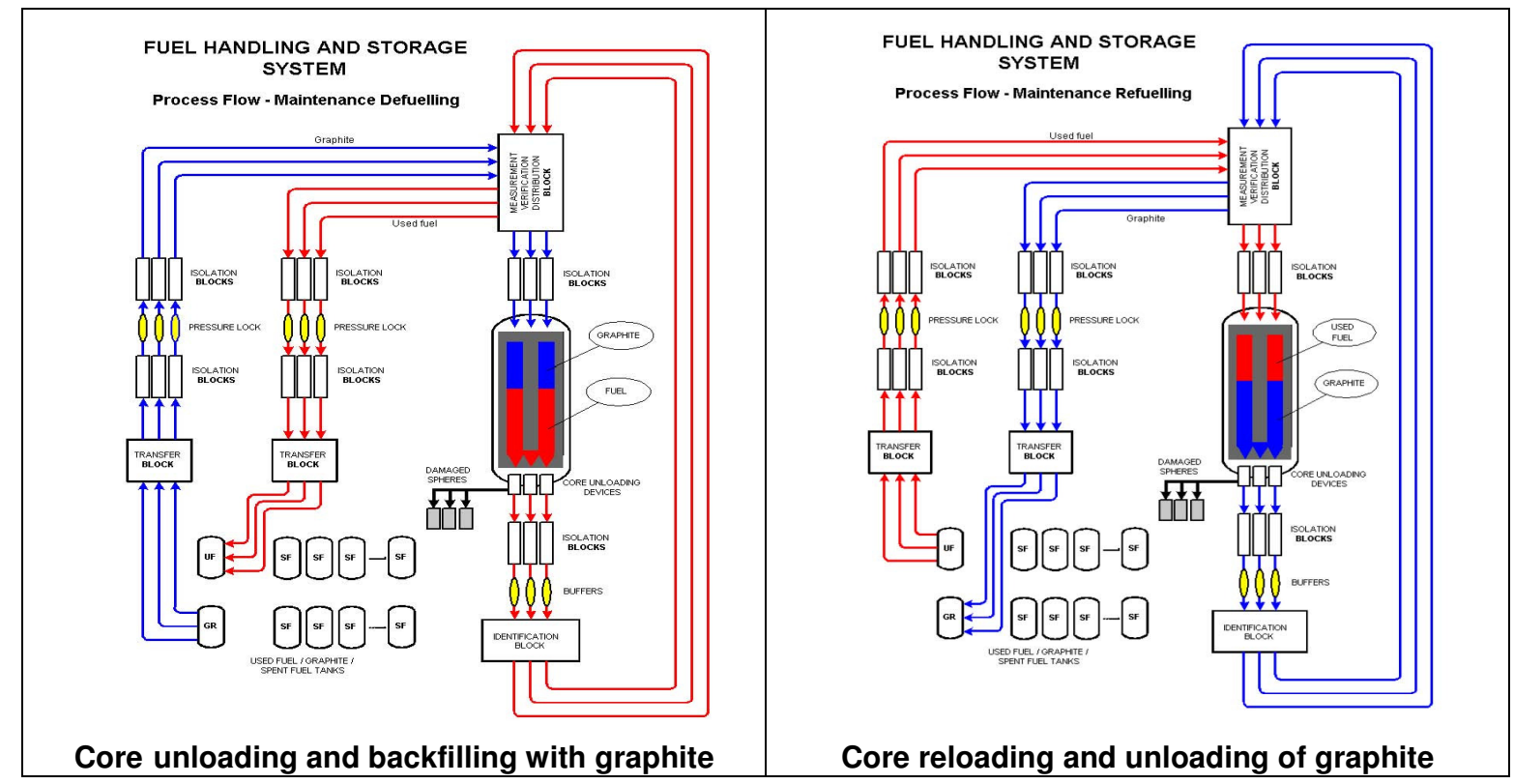

Fig. 1.9. PBMR core unloading and reloading during maintenance shutdowns.

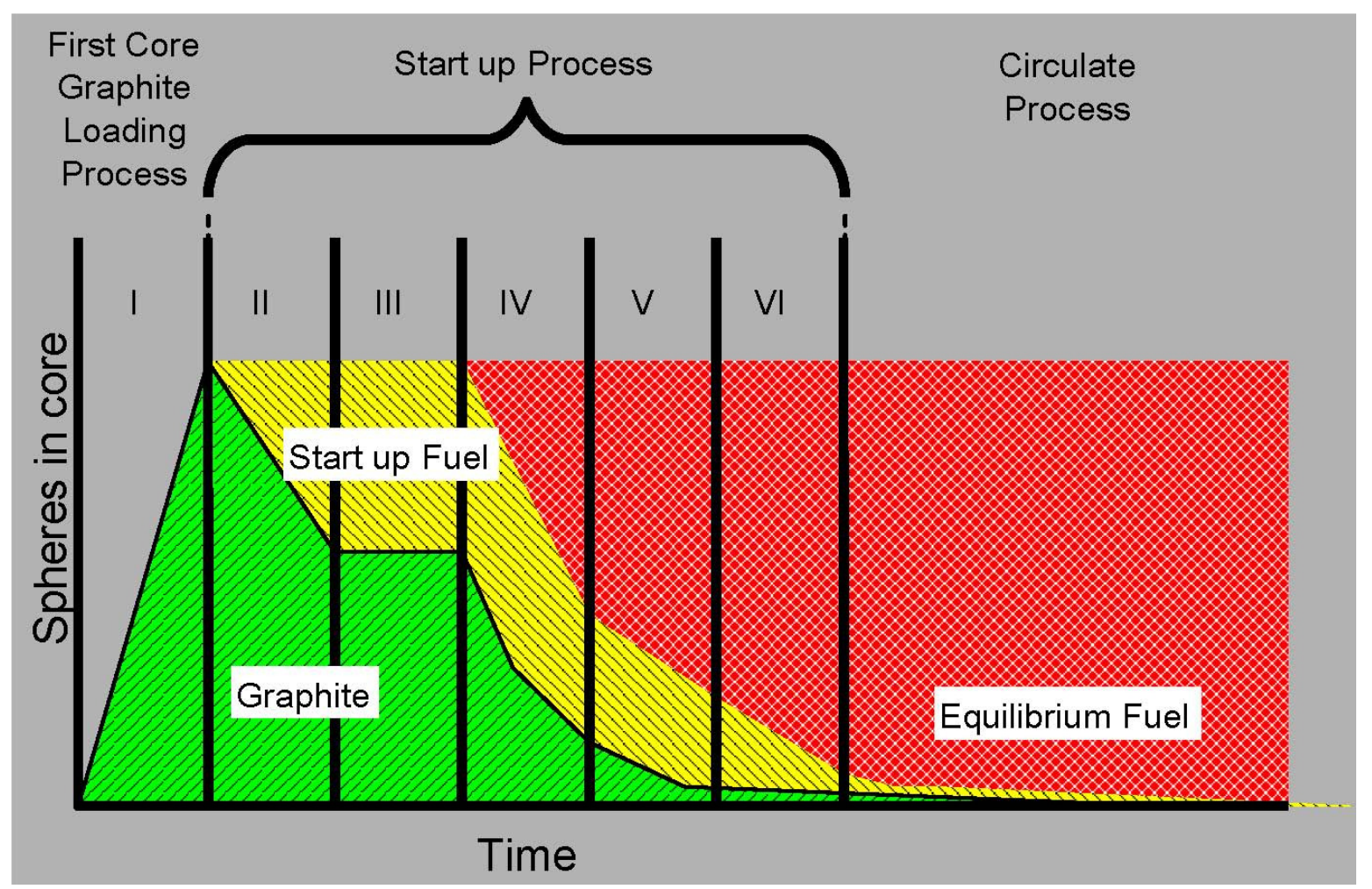

Fig. 1.10. PBMR core discharge inventories (graphite, start-up fuel, and equilibrium fuel) as a function of recirculation timing. 
full power is carried out by removing graphite pebbles and replacing them with a mix of graphite and fresh and irradiated initial core pebbles for the first two recirculation cycles and then loading fresh equilibrium core pebbles ( 9 grams of LEU per pebble at an estimated 9.8 percent enrichment) into the mix of graphite and irradiated initial core fuel pebbles. The steps in this process are listed below as taken from Slide 36 of the presentation on "PBMR Reactor Unit and Main Support Systems" in Ref. 27:

- Initial loading of the core of the reactor with graphite spheres.

- Replacing the graphite spheres with fresh fuel spheres intermixed with graphite spheres during initial start-up.

- Gradually changing the start-up core composition of graphite and fuel to a fuel-only composition, and then to a core consisting of fuel to be used in the equilibrium state.

- Loading and unloading the fuel into and from the reactor core while the reactor is operating at power.

- $\quad$ Spent fuel discharge to spent fuel tanks.

The discharge of the pebble mix to storage is illustrated on Slide 45 in the same presentation and given here in Fig. 1.10. Once start-up is completed and full power is achieved, the core is refueled with a mix of fresh equilibrium core pebbles and irradiated pebbles where the pebbles on the bottom of the core have been burned more than those at the top where the pebbles being loaded consist of a mix of fresh pebbles and on-average less-irradiated pebbles than those being discharged at the bottom of the core.

The introduction of the mix of fresh and less-irradiated pebbles into the top of the core tends to keep the power distribution peaked (or at the highest power density) toward the top of the core analogous to the prismatic VHTR. From Table 1 of Ref. 28, the ratio of fresh pebbles to irradiated/recirculated pebbles loaded into the top of the core each day is $\sim 1: 6$ in the equilibrium core. The recirculation of irradiated pebbles for up to six cycles through the core is managed by monitoring the radiation from irradiated pebbles discharged at the bottom of the core until a pebble is determined by its radiation signature to be at full burn-up ( 91 MWD/MT in the PBMR) where upon it is discharged to spent fuel storage. Graphite pebbles have a very low radiation signature and so are readily distinguished from irradiated fuel pebbles. As illustrated in Fig. 1.10 (from Slide 45 of the presentation on "PBMR Reactor Unit and Main Support Systems" in Ref. 27), the mix of graphite, initial core fuel and equilibrium core fuel pebbles continues to be discharged to spent fuel storage until well into the sixth recirculation cycle of the start-up initial core pebbles, by which time the core will mostly be fueled with equilibrium core pebbles. Irradiated graphite pebbles are stored separately from spent fuel pebbles. Subsequently, defueling of the whole core and replacement of all fuel with graphite pebbles occur when major in-core maintenance is performed such as replacement of the core-facing reflector graphite blocks. Restart following such defueling is again accomplished by unloading the graphite pebbles from the bottom of the core and inserting a varied mix of fresh and irradiated pebbles into the top of the core, so that upon restart the power distribution is again peaked toward the top of the core and relatively flat both radially and azimuthally so as to control the peak fuel temperature

Since there is no serial number for tracking individual pebbles, the NMC\&A for spent fuel is performed by bulk counting of discharged pebbles that meet the full burn-up radiation signature. Recording the count and radiation signature of pebbles discharged to a specific storage tank and then inspecting the storage tank by movable radiation monitors (gamma detectors or fission chambers) is the system proposed by the proponents along with the use of cameras to follow the piping of the Fuel Handling and Storage System to verify that no pebbles are diverted [see Fig. 1.11 taken from Fig. 9 in Ref. 28 or Slide 48 in the presentation on "PBMR Reactor Unit and Main Support Systems" in Ref. 27]. If required spent fuel pebbles may be retrieved from a spent fuel storage tank and recounted, but the design of spent fuel storage tanks must be tailored to accommodate this option. 


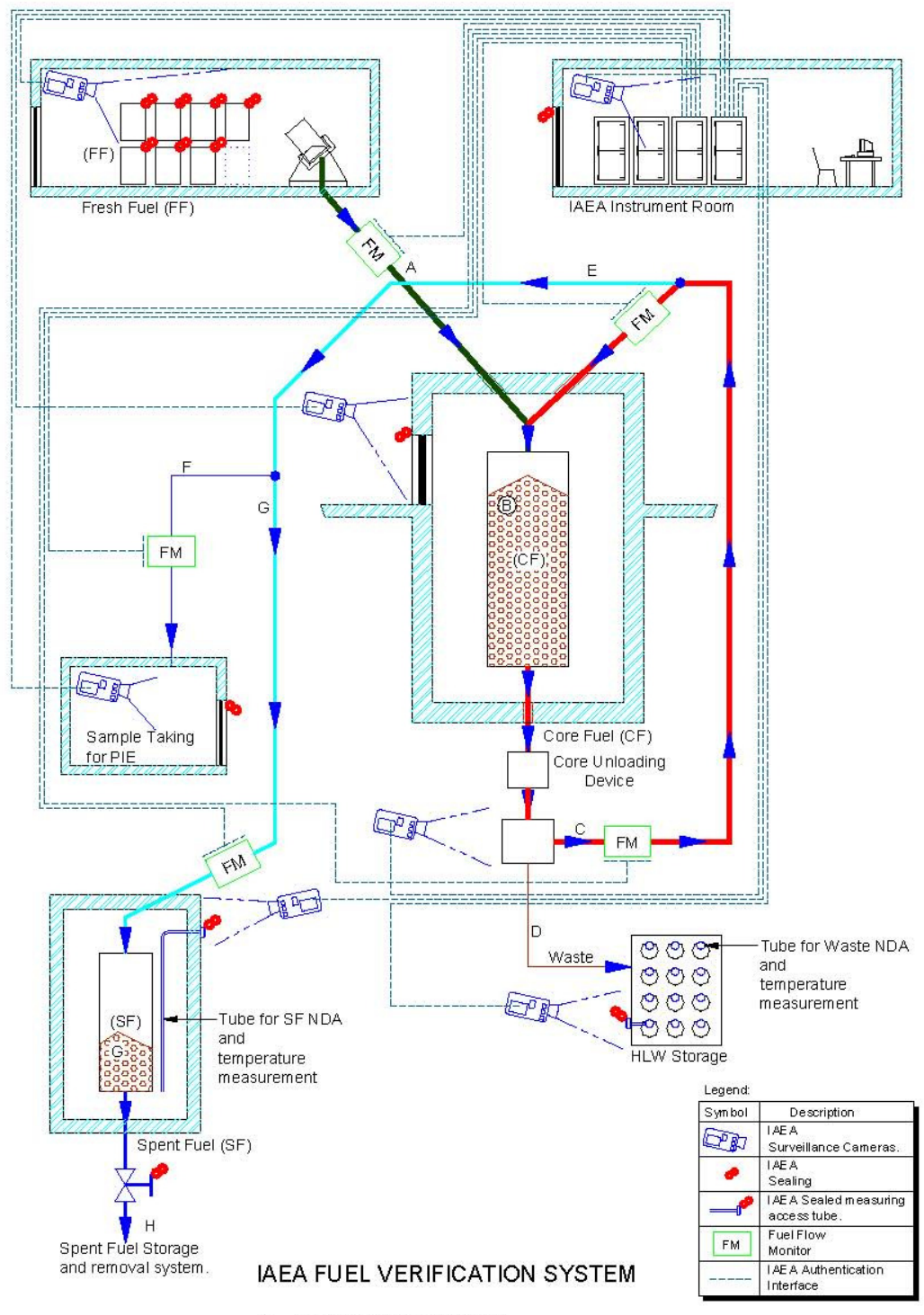

No: MZ000-021379-1117

Fig. 1.11. Schematic of proposed IAEA support measures for the application of safeguards at PBMR. 


\section{OVERVIEW OF FUEL CYCLE(S)}

A comparison of the vendor-proposed VHTR fuel cycle parameters is provided in Appendix B. The information in Appendix B is taken either from the references given in Sect. 1 or from inferences drawn from these references where no specific information has been provided by the vendors.

The baseline fuel cycle for the first-generation VHTR is the once-through fuel cycle using LEU fuel. The Russians are simultaneously pursuing the GT-MHR as a "deep-burn" option for weapongrade plutonium disposition [9]. The use of high enriched uranium (HEU) as HTGR fuel, as was done in the past, is no longer considered acceptable due to the very low proliferation resistance of HEU. Both GA and Areva are considering a range of other fuel cycle options for future reactor deployments including plutonium disposition, transuranic (TRU, plutonium-neptunium plus other more radioactive minor actinides) and/or minor actinide (MA, neptunium, americium, and potentially curium)

transmutation, and the use of thorium $\left({ }^{232} \mathrm{Th}\right)$ as a fertile component for high-conversion fuel [38-43]. Each of these options, including the so-called deep-burn options, is currently based on an initial oncethrough irradiation without recycle, although technologies to reprocess and recycle TRISO fuel are also under either consideration or initial development and were studied extensively in the past at laboratory and pilot-scale for HEU/Th fuels. The ongoing research and development and the past experience provide a reasonably sound basis to have confidence in the ability to close the VHTR fuel cycle in the future, if needed.

The fuel cycle options for VHTRs can be categorized in three ways described as follows.

First, VHTRs can operate with either pebble or prismatic fuels. Pebble bed reactors operate with on-line refueling. This enables operation with very low excess reactivity, typically only sufficient to overcome the neutron poisoning effects of xenon that occur following power reductions. Prismatic fueled reactors require periodic refueling outages and thus operate with substantially higher average excess reactivity, but allow substantially greater flexibility in fuel zoning and shuffling.

Second, VHTR fuel cycles can be categorized by the types of fuel particles used as follows:

- LEU fuel particles with or without natural uranium fertile fuel particles

- Plutonium fuel particles

- TRU or MA fuel particles

- $\quad{ }^{233} \mathrm{U}$ fuel particles (or ${ }^{233} \mathrm{U}$ with ${ }^{238} \mathrm{U}$ )

- Thorium (or thorium with uranium) fertile fuel particles

- $\mathrm{Pu} /{ }^{232} \mathrm{Th}$ and $/$ or $\mathrm{Pu} /{ }^{238} \mathrm{U}$ in mixed oxides (MOX)

The first four types of particles contain fissile isotopes that are required to support criticality of the reactor. The LEU particles also contain the fertile isotope ${ }^{238} \mathrm{U}$ and may contain in some designs fertile particles of natural uranium [5-7]. However, with the VHTR's thermal spectrum, thorium has substantially better properties as a fertile isotope, so for core designs that add fertile material, thorium fuel particles may replace the use of natural uranium in the future $[5,6]$. This thorium may be mixed with a small amount of uranium to dilute and "denature" the fissile ${ }^{233} \mathrm{U}$ produced by neutron absorption in thorium. In general, it can be expected that future VHTR reactors will operate with fuels composed of some mix of the six particle types listed above. Each particle type involves specific technical issues for fabrication, with some being more challenging than others.

Third, VHTR fuel cycles can be categorized by whether or not the spent fuel is discarded or recycled. Recycle may occur with either aqueous or pyroreprocessing methods, and recycled materials may be returned to VHTRs or sent to fast reactors.

The fabrication of VHTR fuel particles, independent of the constituent fissile or fertile materials, has the same basic steps: 
- The use of a chemical solution deposition (sol-gel) process to form the fuel kernels as microspheres followed by selective quality control acceptance inspections to ensure uniformity in sphericity, density/porosity, and kernel composition and stoichiometry,

- The high-temperature coating of the fuel kernels by multi-pass reactive-flowing-gas fluidized-bed chemical vapor deposition (CVD) in a furnace to form the multi-layered coated fuel particles followed by selective quality control acceptance inspections of coatings integrity,

- The compacting of the coated fuel particles with a carbon-based blending material and the subsequent graphitization of the compacted coated fuel particles in the carbon matrix to form the final fuel compacts again followed by selective quality control acceptance inspections, and

- At each step, defective or damaged kernels or coated particles are collected as scrap, and the nuclear material is recovered and processed for refabrication as fuel to minimize radioactive waste generation.

Although the fabrication steps are common to each VHTR fuel type, due to the variations in radioactivity of the fuel materials, substantially different approaches are needed for the different types of fuel material to carry out the fabrication steps listed above. LEU or thorium TRISO particles may be fabricated with direct-contact handling and standard personnel safety, physical security and safeguards effort similar to that as currently applied in the fabrication of light water reactor (LWR) LEU fuel. Plutonium particles must be fabricated in glove boxes, with substantially increased safety, physical security, and safeguards effort typical of those measures adopted for LWR mixed oxide (MOX) fuel fabrication. TRU/MA and ${ }^{233} \mathrm{U}$ particles must be fabricated using remote handling methods in hot cells, simplifying safety and physical security requirements but complicating issues for reliability due to the complexities of the fabrication steps and requiring new approaches for addressing remote nuclear material accountability to achieve safeguards objectives.

At this stage of development, it must be remembered that only the LEU fuel is currently under active development and qualification and that all other particle types are yet to be developed and qualified to meet both (1) performance objectives for fission product retention under both normaloperations irradiation and temperature-transient accident conditions and (2) demonstrated reproducible quality assurance/control in industrial-scale fabrication. These development and deployment efforts will likely constitute approximately, or at least, \$100 million investment and will most likely be required for each particle type to meet respective licensing and regulatory requirements of the USNRC (Sect. 4.2, "Fuel System Design," currently Revision 3, of the USNRC Standard Review Plan [44]) or alternatively, for example, the Russian Federal Service for Ecological, Technical and Atomic Supervision (Rostekhnadzor) [45] and the industrial State Standards of the Russian Federation ("gosudartsvennye standarty" or GOSTy or GOST) [46]. Qualification of different fuel particle types will not be completed based solely on laboratory-scale fabrication and research reactor irradiations of test fuel, but, in both the U.S. and Russia, the licensing of new fuel particle types requires the completion of several cycles of core irradiations of fuel fabricated in industrial-scale, quality-assured fuel fabrication facilities. Qualification of the LEU and plutonium fuel now under development is still years away to meet licensing and regulatory requirements.

The technical issues of spent fuel disposal and reprocessing technologies relevant to alternative future fuel cycles are discussed in Appendix C. Appendix C also addresses the past development efforts for HTGR fuel reprocessing and refabrication for the HEU/Th cycle as relevant to the LEU and future fuel cycles. However, a common point of technical interest with respect to both

\footnotetext{
*Kernel formation may also involve the addition of oxygen getters to control fission product chemistries or inert matrix diluents to reduce the fissile inventory or both thus complicating quality control inspections of the kernels [39].
} 
(1) potential volume-reduction for spent fuel disposal and (2) reprocessing technologies that permit fuel reuse/refabrication for achieving partial sustainability in the alternative future fuel cycles is the technology required to remove the ${ }^{14} \mathrm{C}$-contaminated graphite and other carbon-based material from around the coated particles in the spent fuel [47-56]. However, generally once the encased fuel kernels are removed and the particle coatings (particularly the $\mathrm{SiC}$ or $\mathrm{ZrC}$ coating layer) cracked $[57,58]$, any reprocessing technology (PUREX or other) can be used to recover and separate the actinides and fission products.

Except for ongoing research and development for the LEU once-through cycle and the historic testing and use of HEU/Th, all other fuel cycles for the VHTR represent future possibilities given also that there is likely to be several years and a significant financial investment for supporting research (including irradiation testing of laboratory-scale, pilot-scale, and industrial-scale fabrications of candidate fuels) to qualify the fuel forms for the alternative fuel cycles. Currently, only the LEU fuel is being tested for qualification, so alternative fuel options are likely years away in development.

Further, reprocessing technologies for VHTR fuels are not currently developed because it will need a a proven and economic head end process to separate the fuel particles from the graphite matrix. The grind-leach, burn-leach and electrolysis in nitric acid technologies studied for reprocessing HEU/Th fuels must still be developed beyond the laboratory and pilot scale and yield large quantities of ${ }^{14} \mathrm{C}$-contaminated $\mathrm{CO}_{2}$ or carbon sludge that must be disposed safely. 



\section{PR\&PP RELEVANT SYSTEM ELEMENTS AND POTENTIAL ADVERSARY TARGETS}

The "system elements" for the VHTR are described as follows:

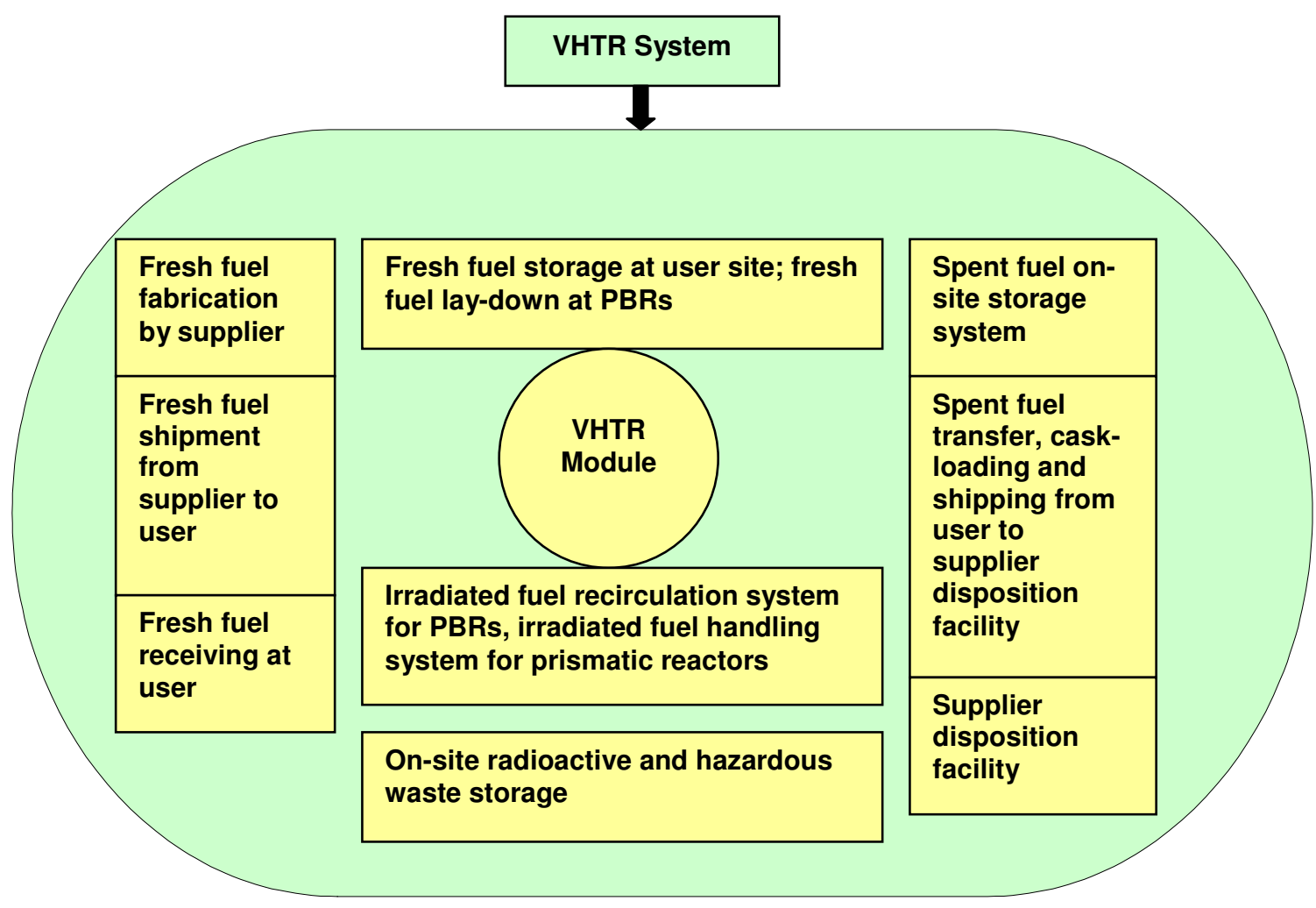

Fig. 3.1. Diagram of VHTR nuclear system elements.

Key high-level information defining the VHTR system elements includes the following.

- Material types existing within each system element or grouping of system elements

- Fresh fuel: LEU in currently planned VHTRs; weapon-grade plutonium in future Russian GT-MHR; plutonium or TRU in future deep-burn VHTRs; and LEU/Th or Pu/Th MOX in future converter VHTRs. As raw material for fresh fuel fabrication (LEU-uranium hexafluoride, nitrate, or oxide; Pu-bearing — plutonium metal, nitrate or oxide; TRUnitrates or oxides; and LEU/Th-hexafluoride, nitrate or oxide). The material is most attractive since the least amount of effort would be needed either to enrich indirect-use uranium or to handle direct-use plutonium for nuclear weapon fabrication. As currently practiced, appropriate accounting measures and physical protection should be utilized as assurance to preclude theft or diversion of the the nuclear material used for manufacturing the fresh fuel. Once encased in graphitized carbon as TRISO-coated particle fuel in fuel elements (pebbles or prismatic blocks), recovery becomes more difficult involving processes similar to reprocessing except for the presence of fission products and activation products such as ${ }^{14} \mathrm{C}$.

- Irradiated and spent fuel with fission products: Irradiated LEU with small amounts of plutonium in currently planned VHTRs; irradiated/isotopically degraded plutonium in future Russian GT-MHR; irradiated TRU in future deep burn VHTRs; irradiated LEU/Th with both plutonium and ${ }^{233} \mathrm{U}$ in future converter VHTRs; and radioactive or other 
hazardous wastes especially those solid, liquid, and gaseous materials collected for storage and/or disposal during operations and maintenance of any reactor type.

Reprocessing is required to recover usable weapon-grade material, but, as is the case for all spent fuel, breakage and dispersal of radioactive irradiated fuel is potentially attractive as a means of effecting radiological sabotage.

- Operations envisioned to occur in a system element, and whether (and how) these operations can be modified or misused

- Fresh fuel: Operations include fabrication by supplier, shipment from supplier to user, receiving and storage at user's site. Theft is an issue in each element dealing with fresh fuel for the acquisition of either indirect-use ${ }^{235} \mathrm{U}$ in the current baseline concepts or direct-use plutonium in future plutonium and TRU fueled concepts, but recovery of weapon-usable material is made difficult by the form of the fuel (particles embedded in graphite matrix) where recovery would necessarily involve processes similar to reprocessing except for the lack of presence of fission products and activation products such as ${ }^{14} \mathrm{C}$. Fabrication is where a deliberate act or inadvertent error in quality control can lead to fuel failures and radioactive releases from the damaged fuel during irradiation as an act of radiological sabotage. Fabrication also involves scrap recovery and recycling within the supplier's fuel fabrication facility with non-recoverable scrap stored for disposition as low-level radioactive waste. Broken fresh fuel elements would be stored separately by the user for shipment back to the supplier for recycling as unirradiated scrap.

- Irradiated fuel: Operations include irradiation in reactor, recirculation (pebble bed) of irradiated fuel, reloading (prismatic) of irradiated fuel into reactor, irradiated and spent fuel storage, radioactive waste handling and storage, loading irradiated and spent fuel or radioactive wastes into shipping casks for off-site shipment, shipment of spent fuel or radioactive wastes for disposition, and processing of spent fuel for disposition by supplier. Diversion and theft of irradiated material is the principal threat for the acquisition of potentially nuclear weapon-usable material (enriched uranium, plutonium, or ${ }^{233} \mathrm{U}$ ) that still must be recovered from irradiated fuel elements by reprocessing and for uranium by both reprocessing and subsequent enrichment. Theft of smaller quantities of such material can result in their use for radiological sabotage. Sabotage of the reactor during fuel irradiation or shutdown operations or sabotage of spent fuel storage tanks or shipping casks can potentially lead to radiological releases to the environment as an act of radiological sabotage. Special handling of damaged irradiated fuel would likely include separated canned storage at the user's site with a negotiated disposition path including shipment back to the supplier.

- Material movements in and out of a system element

- Fresh fuel fabrication: Raw constituents of fresh fuel are brought into the fuel fabrication facility (LEU—uranium hexafluoride, nitrate, or oxide; Pu-bearing - plutonium metal, nitrate or oxide; TRU—nitrates or oxides; and LEU/Th — hexafluoride, nitrate or oxide), and fabricated fuel elements (prismatic blocks or pebbles) containing graphitized-carbonencased TRISO-coated fuel particles are shipped out. Fuel scrap is recycled internally at the supplier's fabrication facility with non-recoverable fuel scrap-waste stored on-site and ultimately shipped off-site for disposal as low-level radioactive waste.

- Fresh fuel shipment to, receipt by, storage at, and irradiation by user facility: Except for irradiation, all movement in and out of the listed system elements is that of fresh fuel; damaged fresh fuel is collected, stored and returned to supplier for scrap recovery. 
Diverted or stolen fresh fuel must still be processed using the same methods for reprocessing spent fuel to remove the carbon and $\mathrm{SiC}$ in order to recover the fissile material content.

- Irradiation, handling of irradiated fuel for recirculation (pebbles) or reloading (prismatic) or spent fuel storage, spent fuel storage, loading for off-site shipment, shipment for disposition, and the handling and storage of radioactive wastes: Except for irradiation and radioactive waste handling and storage, all movement in and out of the listed system elements is that of irradiated or spent fuel. Radioactive waste handling and storage involves all fluids and solids that are contaminated with fission and neutron-activation products that end up in either the off-gas system or the solid and liquid waste systems for storage and ultimate disposition as low-level radioactive waste; the wastes are primarily generated by the helium purification system and routine maintenance of the reactor and auxiliary systems.

- Safeguards and security envisioned to exist in the system elements

- All facilities and operations will be subject to the provisions of the supplier and user states' Safeguards Agreement with the IAEA, the Additional Protocol, the Convention on Physical Protection of Nuclear Materials for international shipments of nuclear material, the Agency's guidance on The Physical Protection of Nuclear Materials and Nuclear Facilities, and the nuclear material, equipment and technology transfer commitments of the members states of the Zangger Committee and the Nuclear Suppliers Group.

- Within facilities, measures shall be taken to assure Containment and Surveillance (C/S) and the Continuity of Knowledge (CoK). For prismatic fuel VHTRs, CoK shall be established by the visual tracking of serial-numbered fuel elements from fabrication to disposition. For pebble fuel VHTRs, CoK shall be established by counting of fresh fuel elements and by bulk accountability methods that may include for spent fuel both counting elements and active neutron interrogation techniques to quantify the fissile inventory to within acceptable levels of uncertainty.

Assuming that the most likely adversary targets are those presented in the user state, then fresh fuel is the most likely target for theft or diversion. For this reason, LEU and LEU/Th fuels are best suited for export to user states containing only indirect use ${ }^{235} \mathrm{U}$ in LEU with the use of Pu-bearing fuels reserved for use in supplier states for weapon material disposition and-deep burn of TRU. However, recovery of usable nuclear material from either fresh or irradiated VHTR fuel involves the processes needed to remove large quantities of carbon for a small yield of nuclear material. 



\section{PROLIFERATION RESISTANCE CONSIDERATIONS INCORPORATED INTO DESIGN}

The key proliferation resistance feature of the VHTR fuel system is the fuel itself. To obtain a significant quantity of either indirect-use ${ }^{235} \mathrm{U}$ from LEU (75 kilograms) or direct-use plutonium (8 kilograms), one has to process metric ton and tens of cubic meter quantities of carbon encasing coated particles using either grind-leach, burn-leach, or electrolysis in nitric acid. For irradiated LEU fuel, the high burn-up of the discharged spent fuel (>80 GWD/MT) provides highly radioactive fuel with poor plutonium isotopics for weapons usage, and the difficulty of reprocessing the spent fuel involves removing massive amounts of ${ }^{14} \mathrm{C}$-contaminated carbon to retrieve a very small quantity of plutonium per fuel element. The most attractive fuel form for diversion would be weapon-grade plutonium oxide proposed for plutonium disposition in Russia, and this fuel form would most likely not be exported out of country. If, in the future, MOX or TRU oxides for deep-burn were to be qualified as licensable fuel forms, such fuel would also be less likely to be exported until LEU availability runs out, by which time advanced safeguards will have been developed and implemented for the export of potential breeder fast reactors.

In the following discussion of each of the candidate fuel types proposed for the VHTR, reliance is made on reported results from the PBMR to draw inferences about LEU fuel in the prismatic cores since the prismatic core designers have not yet reported fuel cycle data in as much detail.

The Baseline LEU Cycle: The key proliferation resistance features of the VHTR candidate systems are the use of the once-through baseline fuel cycle using LEU fuel irradiated to high burn-up ( 90-100 GWD/MT or greater except for the HTR-PM at $80 \mathrm{GWD} / \mathrm{MT}$ ) and the fact that the produced actinides in the coated fuel particles encased in graphite and graphitized carbon where the fuel particles are not readily accessible to be reprocessed and contain high levels of the less desirable plutonium isotopes, namely ${ }^{240} \mathrm{Pu}$ and ${ }^{238} \mathrm{Pu}$.

The impact of using LEU fuel in the VHTR where the uranium is enriched above the enrichment used in LWRs can be assessed as follows. Using the PBMR as an example, since most likely pebble fuel elements are not going to be inscribed with tracking serial numbers as is the case in the prismatic fuel, the diversion of an indirect-use significant quantity (75 kilograms) of ${ }^{235} \mathrm{U}$ in LEU in fresh pebbles would require, for the equilibrium core with a pebble loading of 9 grams of LEU at $9.6 \%$ enrichment, $75,000 /(9 * 0.096)=86,806$ pebbles or $\sim 17.4 \mathrm{MT}$ of fuel pebbles, which should be quite readily detectable even over time since that is $\sim 20$ percent of a core loading [28]. By comparison, for the prismatic core GT-MHR or MHTGR using fuel elements with inscribed serial numbers for visual tracking, the diversion of an indirect-use significant quantity (75 kilograms) of ${ }^{235} \mathrm{U}$ in LEU in fuel elements containing $\sim 3.43$ kilograms of LEU on average at $19.8 \%$ enriched would require $75 /(3.43 * 0.198)=\sim 111$ fuel elements or 13.5 MT of fuel elements, which would be $\sim 15-16 \%$ of a GT-MHR core loading or $\sim 17 \%$ of the MHTGR core leading [5-7, 82, 83]. Thus, the mass ratio for the diversion of indirect use ${ }^{235} \mathrm{U}$ in LEU between fresh pebbles and fresh GT-MHR fuel elements is $17.4 / 13.5=\sim 1.29$ so that $29 \%$ more pebbles by mass would have to be diverted to obtain 75 kilograms of indirect use ${ }^{235} \mathrm{U}$ in LEU. A volumetric comparison can also be made where the GT-MHR or MHTGR prismatic element has a physical volume of $0.0889 \mathrm{~m}^{3}$ [Table 3-4 in Refs. 5 and 6], where a cylinder occupied by a single prismatic fuel element is $\sim 20 \%$ larger by volume, while a single $60 \mathrm{~mm}$ diameter pebble has a volume of $0.000113 \mathrm{~m}^{3}$ with a packing fraction in small volumes that would vary between 50 and 60 percent at most so that the gross volume occupied when stacked in a small container would be between 0.000226 and $0.000272 \mathrm{~m}^{3}$. Diverting 111 prismatic fuel elements requires a net container volume of at least $\sim 9.86 \mathrm{~m}^{3}$ where the prisms are optimally stacked in some sort of cylindrical container, increasing the volume by 5-20\% depending on the number prisms, and diverting 86,806 pebbles requires a net container volume of at least $\sim 24 \mathrm{~m}^{3}$ if several small containers are used or $\sim 20 \mathrm{~m}^{3}$ if larger containers are used to increase the packing fraction, which would take time to do. Thus, the minimum gross volume ratio for the diversion of 
indirect use ${ }^{235} \mathrm{U}$ in LEU between fresh pebbles and fresh GT-MHR or MHTGR fuel elements is at least $\sim 19 / 9.86=<2$.

Because the fuel elements of PBMRs lack serial numbers for tracking, the use of LEU-fueled PBMRs has been examined by several researchers from the aspect of the attractiveness for diversion of fully burned spent fuel, one-cycle-irradiated pebbles, and the use of special production pebbles $[28,59-63]$. These studies have demonstrated in calculational results that, at full burn-up, the isotopic composition of the produced plutonium is less attractive than that of fully burned LWR spent fuel (at $\sim 55 \mathrm{GWD} / \mathrm{MT}$ ), with ${ }^{239} \mathrm{Pu}$ being less than $50 \%$ of the total plutonium (see Table 4.1 taken from Ref. 63).

Table 4.1. Calculated plutonium isotopic fractions for PBMR spent fuel as a function of initial enrichment and discharge burn-up [Table 3-2 from Ref. 63]

\begin{tabular}{|c|c|c|c|c|c|c|}
\hline \multirow{2}{*}{$\begin{array}{c}\% \\
\text { Enrichment } \\
(\bigcup-235)\end{array}$} & \multirow{2}{*}{$\begin{array}{l}\text { Average } \\
\text { Discharge } \\
\text { Burnup } \\
\text { (MWd/kg) }\end{array}$} & \multicolumn{5}{|c|}{ Pu Isotopic Fractions } \\
\hline & & Pu-238 & Pu-239 & Pu-240 & Pu-241 & Pu-242 \\
\hline $7 \%$ & 70 & $1 \%$ & $46 \%$ & $29 \%$ & $15 \%$ & $9 \%$ \\
\hline $8 \%$ & 80 & $1 \%$ & $46 \%$ & $28 \%$ & $16 \%$ & $9 \%$ \\
\hline $10 \%$ & 100 & $1 \%$ & $46 \%$ & $26 \%$ & $17 \%$ & $11 \%$ \\
\hline $15 \%$ & 150 & $2 \%$ & $44 \%$ & $23 \%$ & $18 \%$ & $13 \%$ \\
\hline $20 \%$ & 200 & $4 \%$ & $42 \%$ & $20 \%$ & $19 \%$ & $15 \%$ \\
\hline
\end{tabular}

The calculational results for the plutonium isotopic fractions in the PBMR fully burned spent fuel would likely be very close to those for the prismatic VHTR spent fuel where the prismatic fuel is to be discharged at a burn-up exceeding $100 \mathrm{GWD} / \mathrm{MT}$ (or MWD/kg). The PBMR and prismatic VHTR spent fuel will have slightly different plutonium isotopic compositions resulting from differences in the thermal-neutron and epithermal-neutron energy spectra due to a different moderator-to-fissile atom ratio and additional thermal and epithermal neutron self-shielding due to the higher-density fuel compacting used in the prismatic fuel. The documentation for the GT-MHR on the LEU once-through cycle [9] does not provide typical plutonium isotopic fractions for GT-MHR spent fuel but does state that "The GT-MHR spent fuel has very high proliferation resistance because the quantity of fissile material (plutonium and uranium) per GT-MHR spent fuel element is low, the plutonium isotopic composition is unattractive and there is neither a developed process nor capability anywhere in the world for separating the residual fissionable material from GT-MHR spent fuel." It is expected, however, that the spent LEU fuel from both the GA GT-MHR and Areva Modular HTR will have plutonium isotopic fractions very close to the values calculated for the PBMR in Table 4.1.

Because the PBMR recirculates a pebble up to six times through the core before it is discharged to spent fuel storage at full burn-up ( 92 GWD/MT), the question arises about the diversion of an irradiated pebble after one cycle or the use of special pebbles designed as target elements to produce plutonium. The analysis of the PBMR by PBMR (Pty) Ltd. [28] shows in Fig. 4.1 the plutonium build-up per pebble and the relative isotopic content as a function of recirculation.

Figure 4.1 indicates that at full burn-up each pebble will contain about 0.11 grams of plutonium with the isotopics indicated, and, from this, it can be inferred that, at full burn-up (120 GWD/MT in the GT-MHR), the prismatic fuel elements can be estimated to contain on the order of 60-70 grams of plutonium of similarly degraded isotopics. This estimate accounts for the fact that, with fuel loadings not given for the other prismatic designs (see Appendix B), the prismatic GT-MHR fuel contains onaverage 0.995 kilograms of natural uranium in addition to the 3.43 kilograms on-average of LEU in fresh fuel and reaches $\sim 120 \mathrm{GWD} / \mathrm{MT}$ at full burn-up. Therefore, at full burn-up, the plutonium content equivalency between the serial-numbered average prismatic fuel element and the number of discharged fully-burned non-serial-numbered pebbles is estimated to be approximately a numerical 


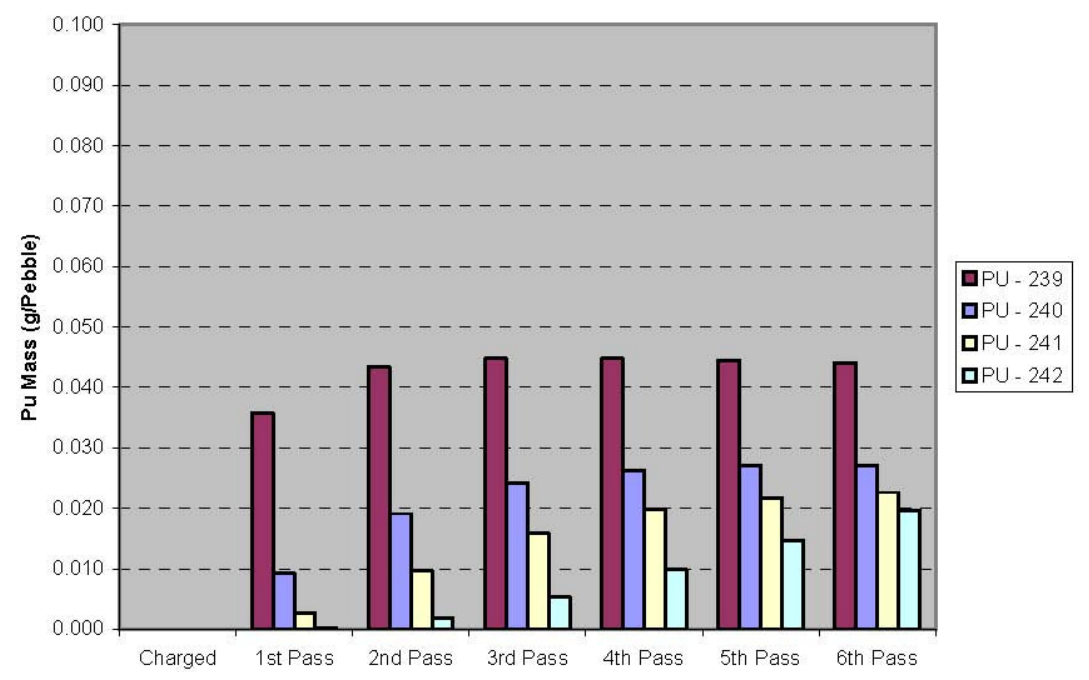

Fig. 4.1. Plutonium build-up in a PBMR fuel element in an equilibrium core [28].

ratio of 1:590, where the equivalent number of pebbles is estimated by dividing 65 grams per prism by 0.11 grams per pebble equaling $\sim 590$. The comparative fuel element mass ratio is 122 kilograms divided by $590 * 200$ grams per pebble, or $122 / 118=\sim 1.02$.

However, the LEU pebble in a PBMR is recirculated up to six times while the fuel element in a GT-MHR or MHTGR is typically reloaded only once [5-7]. From Fig. 4.1, the plutonium content of a pebble after its initial irradiation is given as $\sim 0.047$ grams $\left(\sim 74 \%{ }^{239} \mathrm{Pu}\right)$, whereas for the GT-MHR there are no data quoted for the one-cycle-burned prism but it is inferred that the plutonium loading would be $\sim 50$ grams with less favorable isotopics than in the pebble after one cycle of irradiation. From this, a rough comparison can be made that it would take at least $\sim 1050$ pebbles diverted after the first cycle to equal the amount of less favorable plutonium in a prismatic fuel element removed from a GT-MHR after the first irradiation. Unfortunately, the ${ }^{239} \mathrm{Pu}$ content shown in Fig. 4.1 does not match the value quoted in Table 3.3 of Ref. 63 where the latter value differs by about a factor of 2 , implying that the number quoted in Ref. 63 may more likely be the total plutonium content and not merely ${ }^{239} \mathrm{Pu}$.

The assessment by the Massachusetts Institute of Technology (MIT) of the potential for diversion of first cycle pebbles (Slide 102 of Ref. 60 and Slide 32 of Ref. 61) indicates that, per the MIT analyses where the isotopic fraction of ${ }^{239} \mathrm{Pu}$ after the first cycle $(82.8 \%)$ is approximately consistent with that (74\%) In Table 4.1, the diversion of a significant quantity of plutonium (8 kilograms) with $82.8 \%{ }^{239} \mathrm{Pu}$ content would require diverting $\sim 285,000$ pebbles or $\sim 57$ MT with a packed volume approaching $\sim 64 \mathrm{~m}^{3}$. The MIT study also calculates that it would take $\sim 20,000$ special covert pebbles to obtain 6 kilograms of plutonium. By comparison, it is estimated to take the diversion of 160 GT-MHR first-cycle-irradiated fuel elements with a total mass of 19.5 MT in fuel elements and a volume of over $14.5 \mathrm{~m}^{3}$ to obtain a significant quantity of plutonium (8 kilograms) where the isotopics would be more like that of the pebble after four cycles of irradiation (that is, $\sim 60 \mathrm{MWD} / \mathrm{MT}$ assuming a linear burn-up trajectory). These are huge masses and volumes of ${ }^{14} \mathrm{C}$-contaminated carbon that are required to be handled to effect diversion of a significant quantity of plutonium for both prismatic and pebble fuels.

The analysis in Ref. 62, which assumes the special pebble contains a metallic $30 \mathrm{~mm}$ diameter sphere of natural uranium, concludes that use of a PBMR "to produce energy and clandestinely produce plutonium for a weapon is impractical and slow, and the plutonium yielded would be of very poor quality." This latter study further noted that "the design of the pebbles is likely to be improper for the retention of fission products and generated gases" so that "ensuing releases could cause health and safety concerns and would most likely make the facility easier to detect." Slide 33 in Ref. 61 
illustrates other concepts for "special pebbles," all of which, assuming a $1 \%$ inventory in the core, would require several tens of thousands of pebbles and several years to obtain 6 kilograms of ${ }^{239} \mathrm{Pu}$ and likely be subject to the detectable release of radioactive fission gases.

Another more recent assessment of pebble bed reactor safeguards challenges for the LEU cycle is presented in Ref. 64. Several key conclusions from this latter study include the following.

- Fuel Source Tracking: The use of tags where the tags are small particles whose chemical composition provides a unique serial number identifier. The tags would be added during the pebble fabrication process and be incorporated into the graphite matrix. If a diverted pebble is recovered or an inspector has a question about where a pebble came from, the tags can be recovered destructively from the pebble. An example of such tags is microspheres of rare earths where a lot is identified by the specific mixture of rare earths.

- Pebble Radiation Inspections during Pebble Recirculation: The pebbles flow through the reactor during irradiation and then upon discharge from the reactor though a detector to determine which pebbles are sufficiently irradiated for disposal and which pebbles are to be recirculated. The radiation profile of a target "special pebble" would be very different from that of a fuel pebble and thus could be detected. It is also likely that a target "special pebble" would have a higher loading of natural or depleted uranium than a normal fuel pebble. This, in turn, implies a higher mass pebble. As a practical matter for potential proliferators, pebble inspection is how the host country would find the target "special pebbles" sorted from the rest of the fuel. There are strong incentives to use the reactor's pebble inspection system as an integral component of the safeguards tracking system.

- Monitoring of Fuel Recirculation Records: The use of a large number of targets implies power and reactivity shortfalls in the reactor. That is, the fresh fuel loading or enrichment or the enrichment of spent fuel will increase to provide the neutrons for the target pebbles. Mismatches between fuel loadings and power output are strong indicators of misuse of the reactor. In this context, the PBMR has a unique feature. All of the spent fuel has approximately the same burn-up. This characteristic makes it potentially easier to compare power production records with fuel usage to determine any potential mismatch.

The inferred analyses discussed above to compare the prismatic and pebble bed fuels on LEU is approximate due to the lack of detailed fuel cycle data for the various prismatic options. However, the common conclusion is that to divert either fresh fuel or irradiated fuel to obtain a significant quantity (75 kilograms of indirect use ${ }^{235} \mathrm{U}$ in fresh LEU fuel or 8 kilograms of plutonium in irradiated LEU fuel) requires diverting over ten metric tons and ten cubic meters of material. The use of serial numbers on the prismatic fuel elements allows for item tracking, and such tracking is required for fuel management in the reactor and is very useful for NMC\&A in spent fuel storage. The lack of serial numbers on the pebble fuel element is of no consequence for fuel management in the reactor that relies on pebble counting and the radiation signature, but this lack raises questions about the accuracy of bulk accounting for NMC\&A. However, as discussed above, the quantities of elements, their masses, and their volumes needed to constitute a proliferation concern for both the PBMR and GT-MHR or MHTGR are substantial so that bulk accountability is reasonable for adequate NMC\&A in both types of reactor. Record keeping and the mechanical ability to reconstitute such records are essential to ensuring adequate safeguards for the pebble bed reactor.

Specific proliferation resistance considerations of each possible fuel cycle other than the LEU once-through are discussed as follows.

Pu Particles: The proliferation attractiveness for fuel cycles using Pu particles is in the potential for diversion of plutonium during the processes leading from separation through irradiation of Pu fuel particles in VHTRs. Countries with the capability to recycle spent fuel and fabricate Pu-based fuels would be less likely to export such fuel, except potentially pebble fuel that could be irradiated for one 
to two passes in an onsite reactor prior to shipment to provide self-protection. Such self-protection could also be valuable for physical protection of $\mathrm{Pu}$ pebble fuel during transportation. After irradiation to typical burn-up levels of $60 \%$ to $70 \%$, Pu deep burn fuel would be quite unattractive for diversion or theft. The fissile plutonium isotope loadings in fresh Pu deep burn fuel is greater than that for ${ }^{235} \mathrm{U}$ in LEU (489 kilograms in the GT-MHR at start-up from Table 3-4 in Refs. 5 and 6) in terms of the mass of fissile material with the plutonium loading never exceeding $1.8 \mathrm{MT}$ in the equilibrium cycle as indicated for the GT-MHR in Table 1 of Ref. 38 and for the Areva Modular HTR as assumed in the analyses reported in Table 3 of Ref. $40 .{ }^{*}$ However, the presence of substantial amounts of ${ }^{240} \mathrm{Pu}$ and ${ }^{241} \mathrm{Pu}$ in reactor-grade plutonium would make the fuel both radioactive from the ${ }^{240} \mathrm{Pu}$ spontaneous fission and the presence of americium as ${ }^{241} \mathrm{Am}$ from the beta decay of ${ }^{241} \mathrm{Pu}$ as the fuel ages and thus be less desirable for use in weapons. Also the alpha particles from the decay of plutonium isotopes produce neutrons in oxide fuel from the interaction with ${ }^{18} \mathrm{O}$ that can be a neutron source almost as large as that from the spontaneous fission of the ${ }^{240} \mathrm{Pu}$. Recovery of a significant quantity of plutonium (8 kilograms) from fresh Pu infertile fuel (commonly referred to as "deep burn" fuel) can be estimated for the GT-MHR by dividing the equilibrium core loading (1.8 MT) by the number of fuel elements (720) to be $\sim 2.25$ kilograms on-average in each fuel element. This would equate to the diversion of $\sim 4$ fuel elements to obtain one significant quantity of plutonium (8 kilograms) or $\sim 500$ kilograms of fueled graphitic material in the diverted fuel elements. While as noted in the footnote above pebbles will likely be more lightly loaded than the LEU 9 grams of heavy-metal per pebble if non-fertile plutonium were used as the fissile loading, the minimum number of pebbles required to be diverted for one significant quantity of plutonium can be estimated to be greater than $(8000 / 9)=\sim 889$ or $\sim 177$ kilograms of fueled graphitic material. Obviously for the all plutonium-fueled core, the diversion potential is much greater than for irradiated LEU fuel due to the significantly higher concentrations of plutonium in the deep-burn core. For plutonium-bearing MOX fuel, the numbers of elements that would be required to be diverted to obtain one significant quantity of plutonium will be much closer to one-tenth (8/75) of that for LEU where the presence of large amounts of ${ }^{238} \mathrm{U}$ will provide the reactivity compensation that the use of erbium provides in the all plutonium core. However, plutonium recovery from diverted fuel elements would entail the same procedures and methodologies needed to reprocess VHTR coated particle spent fuel except for not having to deal with fission products and ${ }^{14} \mathrm{C}$ in the graphite and graphitized carbon that would be present in spent fuel. Here again, the complexities of reprocessing coated particle fuels have not been demonstrated on an industrial, practical scale and would involve more steps and expense than recovering reactor-grade plutonium from fresh MOX in LWR fuel where each LWR MOX fuel assembly ( $~ 500-600$ kilograms in total mass with cladding) would contain approximately two significant quantities (16 kilograms) of plutonium.

Pu particle fuel may be used for the disposition of excess weapons plutonium. This fuel form could logically be pursued in a weapons-state as a disposition path for excess plutonium but would clearly not be exported to a non-weapons state. Theft or diversion of fresh fuel elements would be more attractive than for reactor-grade MOX since the plutonium loadings would exceed those with reactor-grade MOX and have a more attractive isotopic content. Under the likely disposition programs for excess weapons plutonium, this plutonium will be placed under IAEA safeguards to verify its removal from military use. The use of VHTR technology would be expected to substantially change the plutonium isotopic composition and attractiveness for weapons use.

TRU and MA Particles: The deep-burn of plutonium mixed with minor actinides (TRU) would be accomplished by use of fuel particles composed of a mixture of plutonium and minor actinides (TRU particles), or a mix of pure minor actinide (MA) particles with fissile particles (either LEU or

\footnotetext{
*While no quantitative citations of proposed loadings have been found for Pu-fueled pebbles, similar to the proposed approach taken in Ref. 29 to reduce the fissile inventory of the Russian Pu burner GT-MHR, Ref. 76 refers to "the use of inert matrix based fuel kernel to dilute the fissile component," indicating the generally recognized need to reduce the fissile loadings of the $\mathrm{Pu}$-fueled elements.
} 
plutonium particles). The technology for fabricating TRU or MA particles and fuels is only now starting to be developed, so the practicality and licensability of the burner VHTR for these fuel materials are yet to be demonstrated.

Thorium Particles: The long-recognized advantage of the LEU/Th cycle is the possibility of achieving higher burn-up in the thermal-spectrum once-through cycle due to the enhanced in situ production and fissioning of ${ }^{233} \mathrm{U}$ compared to that for ${ }^{239} \mathrm{Pu}$ in the LEU once-through cycle [38]. All of the fissile fuels listed above, plus potentially ${ }^{233} \mathrm{U}$, could be used as the seed particles with thorium particles as fissile material. A nontrivial disadvantage of near-term implementation of an LEU/Th cycle in the United States is that all of the previously readily available thorium has been collected by the Department of Energy and "disposed" in shallow burial at the Nevada Test Site (NTS), with the industrial facilities for processing thorium decommissioned so that needed infrastructure would have to be rebuilt.

The GT-MHR or MHTGR two-particle (smaller fissile and larger fertile) fuel system was selected based on the initial HEU/Th cycles used in Peach Bottom Unit 1 and Fort St. Vrain and adapted first as the LEU/Th concept for the MHTGR (LEUCO fissile and $\mathrm{ThO}_{2}$ fertile).

Subsequently, thorium was dropped in favor of using natural uranium in the fertile particle as the baseline fuel for the MHTGR and GT-MHR conceptual designs [81] to "lower decay heat and attendant peak fuel temperatures during conduction cooldown events." The Areva Modular HTR and the PBMR designs are based on the use of a single particle that is less easily adapted and optimized to use a mixture of LEU with thorium in a single particle since the uranium enrichment would have to increase to maintain the burn-up and is limited to $20 \%$ enrichment.

If the GT-MHR or MHTGR two-particle system were adopted to minimize the diameter of the fissile particle with a larger diameter fertile particle, the differences in the diameters of the coated particles would allow for easier separation of fertile and fissile particles once the graphite and graphitized carbon were removed in post-irradiation reprocessing. However, the recoverable ${ }^{233} U$ from the thorium fertile particles would have several hundred ppm of ${ }^{232} \mathrm{U}$, making the product likely too radioactive for practical unshielded handling except remotely as alluded to above in Sect. 2.0. The remote handling needed for ${ }^{233} \mathrm{U}$ TRISO fabrication would be similar to that needed for TRU/MA deep-burn fuel or target fabrication.

Blending recovered ${ }^{233} \mathrm{U}$ with either fresh or reprocessed LEU would have to account for the fact that the HEU-to-LEU cut-point for non- ${ }^{233} \mathrm{U}$-bearing uranium is $20 \%$ enriched by mass, whereas for ${ }^{233} \mathrm{U}$ blended with ${ }^{238} \mathrm{U}$ the equivalent enrichment in ${ }^{233} \mathrm{U}$ is $12 \%$ by mass $[65,66]$. Therefore, the blending of ${ }^{233} \mathrm{U}$ and ${ }^{235} \mathrm{U}$ in LEU would have to have an equivalent enrichment less than the fissilecontent mass fraction of ${ }^{233} \mathrm{U}$ times $12 \%$ plus the fissile-content mass fraction of ${ }^{235} \mathrm{U}$ times $20 \%$. If the mass fraction of each fissile isotope were 0.5 , the equivalent enrichment of the mixed fissile uranium isotopes would have to be less than $16 \%$ to be considered to be LEU. Unblended ${ }^{233} \mathrm{U}$ is considered equivalent to plutonium in terms of defining significant quantities and physical protection requirements independent of its ${ }^{232} \mathrm{U}$ content and radiation source. On the other hand, uranium-based fuel cycles produce plutonium that cannot be rendered non-weapons-usable by blending with a chemically identical diluent. In this context, the proliferation resistance of closed fuel cycles based upon ${ }^{233} \mathrm{Th} /{ }^{233} \mathrm{U}$ without denaturing may be similar to that of cycles based upon ${ }^{238} \mathrm{U} / \mathrm{Pu}$.

In general, the LEU/Th cycle has some advantages and disadvantages. For open cycles the use of thorium may reduce the quantity of uranium needed, but reprocessing for closed cycles will be as difficult as reprocessing for any other closed HTGR fuel cycle.

Other Proliferation Considerations: While the VHTR may not be ideal for serving as a direct mechanism for proliferation, the technical expertise that will be required to be transferred in an export to the host state to assure safe and economic operation of the reactor may pose the greatest proliferation threat. Therefore, the technologies and skills needed to operate the reactors offer the most significant opportunity for a would-be proliferant country to gain the hands-on understanding needed to build and operate a clandestine production reactor, given the assumed access to natural uranium to fuel such a reactor. Most weapons states used low-temperature graphite-moderated reactor 
technologies (water-cooled, air-cooled and later $\mathrm{CO}_{2}$-cooled) using natural uranium-metal fuel and aluminum or magnesium clad, where graphite is most readily available from its common use to make large-diameter electrodes for aluminum and steel making. These technologies are available off the bookshelf in any library $[67,68]$. Trying to make other than gram quantities of plutonium using small targets inserted for short irradiations in control rod or neutron detector penetrations is likely the only undetectable option in a foreign-deployed VHTR. Such small-scale usage may be helpful as were the initial irradiations in the X-10 Graphite Reactor at the Clinton Laboratories (now Oak Ridge National Laboratory, ORNL) were to develop a knowledge base on the chemistry and metallurgy of plutonium but not to deploy full-scale production. Another likely use is gram quantities of tritium produced in such targets, but the introduction of large quantities of lithium-bearing targets even in the reflector region would likely provide a reactivity change indicator [62, 64].

\subsection{CONCEALED DIVERSION OR PRODUCTION OF MATERIAL}

For large quantities of materials production (plutonium or ${ }^{233} \mathrm{U}$ ), this would likely be detectable by spent fuel accountancy based on radiation monitoring or fuel element counting, by containment and surveillance on fuel storage, or by recorded reactivity deviations in reactor operations [62, 64]. The production of small quantities for research would not likely be detected so readily. As concluded by most studies to date as discussed above in this section, the VHTR does not produce readily accessible, attractive fissile material, and the technologies for reprocessing coated particle fuels are both more complicated and still require development.

\subsection{BREAKOUT}

As noted in Sect. 2, reprocessing has yet to be demonstrated for the coated particle fuels on an industrial scale. If there are multi-lateral contractual provisions for the supply of fresh fuel and the take-back of spent fuel for an exported VHTR, the issue of breakout is further mitigated since there will be either no such material or limited quantities of material to be reprocessed in the user state, but this depends of course on the frequency of take-backs and either IAEA or bilateral inspections of the spent fuel storage facilities.

Breakout by the use of clandestine production facilities is discussed in the following section.

\subsection{PRODUCTION IN CLANDESTINE FACILITIES}

The most likely breakout is the use of the skills obtained in operating a foreign-sold VHTR to construct and operate a much simpler, clandestine graphite-moderated production reactor. The use of a multi-billion dollar exported VHTR under international safeguards and with a fuel take-back contract likely offers only one real opportunity for proliferation, and that is the proliferation of enabling technical knowledge to do something much simpler to achieve the production of weaponsusable plutonium outside the view of international on-lookers. However, this type of information proliferation is unavoidable since it is needed to ensure the host country's ability to operate the VHTR both safely and economically. Even if the supplier-state provides the operators, the host state would still likely require the training of a small staff of knowledgeable regulators unless the IAEA or some other international group is to provide the independent regulatory oversight, which would still likely have staff members from non-weapons states including the host state.

Such a clandestine production reactor facility could include an accelerator-driven (that is, cyclotron-driven) subcritical reactor using either light water moderation or lower-than-exportcontrolled nuclear-grade graphite (that is, non-nuclear-grade graphite) [69] where such devices are now not covered by the IAEA Safeguards Glossary [70] nor the safeguards implementing IAEA Information Circulars [71-73] that define a reactor to be a device capable of achieving criticality, that is, "any device in which a controlled, self-sustaining fission chain reaction can be maintained." 
Whether the clandestine reactor achieves criticality or is a cyclotron-driven subcritical assembly, the user-state operating experience gained from an exported VHTR would include such key technologies as reactor physics analysis, materials (graphite neutron-radiation damage, water-corrosion of metals, use of barite concretes in shielding), low-temperature water chemistry control, instrumentation and control, and other science-based technologies that would make implementation of off-the-shelf [67-69] knowledge much easier to execute. The fuel for the clandestine reactor would be natural uranium metal slugs (in the quantities exempted from safeguards under Paragraph 37 of Ref. 72 but still reportable as to location and use under Article 2.a(vii)(a) of Ref. 73) clad in aluminum (aqueous or air-cooled environment) or magnesium $\left(\mathrm{CO}_{2}\right.$-cooled) alloys where (1) metal fuel is directly amenable to PUREX reprocessing and (2) the mitigation of fuel-damaging uranium-aluminum clad interdiffusion/interactions under neutron irradiation by use of a diffusion barrier (such as nickel or a silicon-aluminum eutectic alloy) is well known historically from the open literature $[74,75]$. 


\section{PHYSICAL PROTECTION CONSIDERATIONS INCORPORATED INTO DESIGN}

This section provides a high-level, qualitative overview discussing those elements of the VHTR system design that create potential benefits or issues for potential subnational threats.

\subsection{THEFT OF MATERIAL FOR NUCLEAR EXPLOSIVES}

Any plutonium, or ${ }^{233} \mathrm{U}$ in future LEU/Th cycles, would be in highly radioactive spent fuel encased in coated particles with fission products, where the material of interest would be quite dilute so that the theft of a significant quantity would require the theft of metric tons of ${ }^{14} \mathrm{C}$-contaminated (along with leaked fission products and other minor activation products) graphite and/or graphitized carbon containing the coated particles. Obtaining access to a significant quantity of plutonium or ${ }^{233} \mathrm{U}$ in the stolen spent fuel would require substantial effort of both mechanical and chemical processing with a resulting product of less than desirable nuclear characteristics, namely, either plutonium with a high inventory of the heavier plutonium isotopes or ${ }^{233} \mathrm{U}$ with hundreds of ppm of ${ }^{232} \mathrm{U}$, making it highly radioactive and requiring further chemical cleaning to remove radioactive decay products that would then reappear within a matter of hours to days after processing. It is judged that the intrinsic qualities of VHTR spent fuel would not make it a desirable target for theft by a subnational group for nuclear explosives.

Deep burn fuels containing Pu or TRU/MA and thorium fuels containing ${ }^{233} \mathrm{U}$ without ${ }^{238} \mathrm{U}$ diluent could be potential targets for theft, particularly during transportation. In this case pebble fuels may have a PP advantage, since it is possible to partially irradiate them with an onsite reactor before transportation, which could use the same shielded canisters used for the return of spent pebble fuel. Another alternative would be to add radioactive spikants to the fuel during fabrication as was previously considered for HEU/Th fuels, but this would increase fabrication costs and need to be assessed. The most economical and practical approach for exported fuels may likely be to use LEU.

\subsection{RADIOLOGICAL SABOTAGE}

As discussed in Sect. 1, the VHTR is designed based on achieving passive-safety by the use of a robust fuel in a reactor that maintains the fuel temperature below fuel-damaging temperatures under all conditions of normal operations and accidents including beyond-design-basis events. The design vision used is that, even if the safety-related RCCS is compromised, heat will still be dumped from the external wall of the reactor vessel such that sufficient heat is removed into surrounding structures so that fuel temperatures in the core do not exceed the levels that would cause the loss of the primary containment provided by the $\mathrm{SiC}$, or $\mathrm{ZrC}$, coatings on the fuel particles. However, the possible objectives for "radiological sabotage" by insider threats could include the following.

- Sabotage of fuel quality and quality control/assurance checks at the fuel fabrication plant in the supplier state

- $\quad$ Sabotage from an insider or intruder threat in the host state either by causing a core heat-up accident by sabotage of shutdown cooling systems or by the deliberate introduction of corrosive chemicals into the primary coolant with simultaneous sabotage of primary coolant contaminant detectors/instrumentation and simultaneous sabotage of the helium purification system

Neither of these strategies would be expected to cause significant off-site consequences but could be very expensive to recover due to lost operations and repair costs and would be highly detrimental to public confidence. Fortunately, it is hard to think of a corrosive chemical that would get through the graphite and graphitized carbon in an expeditious manner and then attack the integrity of all of the $\mathrm{SiC}$ or $\mathrm{ZrC}$ particle coatings; even fluorine gas will not get to the fuel kernel unless the $\mathrm{SiC}$ is already cracked. Using fluorine gas was a method proposed to cull out failed particles in early fuel fabrication. 
There is also the possibility of either an insider threat or a knowledgeable intruder initiating a loss of cooling event with failure to scram. This type of sabotage can lead to recriticality following deliberately initiated beyond-design-basis loss of forced cooling accident and could be exacerbated if accompanied by the deliberate withdrawal of all control rods and the deliberate bypassing of the actuation of the reactor protection system and preventing the operator-actuated scram. The impact of such actions would be that the core temperatures can reach fuel damaging levels during such an insider-initiated event. Such events, without assuming either an insider threat or a knowledgeable intruder as the cause, were analyzed for the MHTGR as indicated in Tables 3.7 and 15.3 of Ref. 35 where USNRC requested the analysis of USNRC-hypothesized Bounding Events. These incredible Bounding Events were analyzed for the MHTGR only to lead to delayed small releases that did not exceed the limits for protective actions (evacuation or sheltering) outside the Exclusion Area Boundary. Since the GT-MHR is physically larger than the MHTGR but has been designed to accommodate the higher power level and larger vessel size without fuel damage, it would be expected that the recriticality Bounding Event sequence discussed in Ref. 35 for the MHTGR would have a similar result for the GT-MHR. This type sabotage scenario would likely bracket the worst-case insider threat by disaffected or compromised operations staff since it can be carried out with a handgun and an access key and does not require carrying in enough shape-charge explosive to penetrate confinement and the reactor vessel.

Another potential insider or intruder threat resulting in radiological sabotage outside the reactor boundary might best be accomplished by stealing small quantities of spent fuel and then explosively smashing it into smaller chunks or pieces in small but strategically located areas.

Based on the discussions above, the most crucial aspects of preventing radiological sabotage in reactor operations are those steps, including physical protection and access controls to sensitive areas on-site to preclude both insider and intruder threats, to ensure the following.

- Quality controls at the fuel fabrication plant in the supplier nation.

- $\quad$ Proper maintenance, inspections and protection of (1) the helium supply and the helium supply station to prevent the introduction of corrosive chemicals, (2) the primary coolant contaminant monitoring equipment to detect the introduction of such chemicals, and (3) the helium purification system to remove contaminants.

- Careful maintenance, inspections, testing, and protection of reactivity control systems to ensure the capability to achieve safe hot and cold shutdown and if required accomplishing the same function from a secure remote location.

- Careful maintenance, inspections, testing and protection of the safe-shutdown cooling system circulator, heat exchanger and power supplies so that, while not safety-related equipment but rather investment-protection equipment, loss of normal cooling upsets do not always lead to reliance on the safety-related reactor cavity cooling system in which fuel temperatures can approach their limits for accident conditions.

- Physical protection of and controlled access to fresh and spent fuel storage locations and to the inbound and outbound transportation loading systems and the transportation of the fresh fuel from the fuel fabrication facility and of the spent fuel to its processing or disposal facilities.

Failure to exercise proper controls of the reactor systems discussed above may not be expected to cause significant off-site consequences because of the design robustness of the fuel and graphite core in resisting damage but could be very expensive events from which to recover due to lost operations and repair costs and would be highly detrimental to public confidence. While the discussion here focuses on radiological sabotage issues from the standpoint of "Physical Protection Considerations Incorporated into Design," as the design matures and specific sites are selected, a comprehensive vulnerability analysis is required for each as-built and sited VHTR. 


\section{PR\&PP ISSUES, CONCERNS AND BENEFITS}

The key areas of known strength in the VHTR concept at this time are its robust fuel, high burnup, and the use of the once-through LEU fuel cycle. Future plans for integration and assessment of PR\&PP for the concept need to address (1) emerging issues from the PR\&PP aspects of alternative fuel cycles that have yet to be realized and (2) the inclusion of PR\&PP aspects in the development of coated particle fuel reprocessing technologies that are as yet not fully developed and demonstrated.

The list of identified PR\&PP R\&D needs for the VHTR system concept may have much in common with the technology gaps that the USNRC requested to be identified and discussed in Ref. 37 that focuses on radiological risk aspects that also impact physical protection considerations for the reactor. Since the passive safety aspects of the VHTR are intimately tied to the reduction in radiological risks from insider threats and outsider attacks on the facility, the technology gaps that relate to assuring passive safety are important to the $\mathrm{PP}$ considerations related to radiological sabotage.

For proliferation resistance, the coated particle fuel encased in graphite and/or graphitized carbon is the major barrier to the ease of recovery, but additional aspects such as adding a radiation barrier or an enhanced radiation barrier not easily removed requires attention both from basic R\&D and from engineering development that will impact the cost of fabrication and handling fresh fuel. The key question is whether such radiation barriers are needed or will they make the cost of using the fuel too expensive for practical implementation. This aspect was partly addressed previously in studying means to provide for deterrence for HEU/Th fuels [77-79] and the potential use of ${ }^{232} \mathrm{U}$-bearing ${ }^{233} \mathrm{U}$ from reprocessed HEU/Th fuels [80], but these options have not as yet been addressed in any engineering detail for the currently envisioned fuel cycle options involving reprocessing and deep burn. The key question is whether such radiation barriers are needed or will they make the cost of using the fuel too expensive for practical implementation. For deep-burn pebble fuels, the option to partially-irradiate fresh pebbles in an on-site reactor prior to transportation may provide some physical protection benefits for theft threats.

In addition, the benefits of a below-grade siting in terms of enhanced physical protection versus cost of construction needs to be assessed in detail for each concept. 



\section{REFERENCES}

1. Evaluation Methodology for Proliferation Resistance and Physical Protection of Generation IV Nuclear Energy Systems, GIF/PRPPWG/2006/005, Revision 5, prepared by the Proliferation Resistance and Physical Protection Evaluation Methodology Expert Group of the Generation IV International Forum (GIF), November 30, 2006, https://inlportal.inl.gov/portal/server.pt/gateway/ PTARGS_0_200_3310_277_2604_43/http\%3B/inlpublisher\%3B7087/publishedcontent/publish/ communities/inl_gov/about_inl/gen_iv__technical_documents/prppem.pdf.

2. Guidance for the Application of an Assessment Methodology for Innovative Nuclear Energy Systems: INPRO Manual-Proliferation Resistance, Volume 5 of the Final Report of Phase 1 of the International Project on Innovative Nuclear Reactors and Fuel Cycles (INPRO), IAEATECDOC-1575/Vol. 5, International Atomic Energy Agency, Vienna, July 16, 2007, http://www.iaea.org/NuclearPower/Downloads/INPRO/Files/5_INPRO\%20PR_manual\%201607-2007\%20pub\%20com.pdf.

3. Guidance for the Application of an Assessment Methodology for Innovative Nuclear Energy Systems: INPRO Manual-Physical Protection, Volume 6 of the Final Report of Phase 1 of the International Project on Innovative Nuclear Reactors and Fuel Cycles (INPRO), IAEATECDOC-1575/Vol. 6, International Atomic Energy Agency, Vienna, July 16, 2007, http://www.iaea.org/NuclearPower/Downloads/INPRO/Files/6_INPRO\%20PP\%20manual\%201 6-07-2007\%20pub\%20com.pdf.

4. Engineering Services for the Next Generation Nuclear Plant (NGNP) with Hydrogen Production-Reactor Containment, Embedment Depth, and Building Functions Study, General Atomics Document No. 911128, Revision 0, September 24, 2008, prepared under Battelle Energy Alliance Contract No. 00075309.

5. M.B. Richards et al., Part 1-H2-MHR Pre-Conceptual Design Report: SI-Based Plant, GA-A25401, General Atomics, Idaho National Laboratory, and Texas A\&M University, April 2006, http://www.osti.gov/energycitations/servlets/purl/883323-D3sgwx/883323.pdf.

6. M.B. Richards et al., Part 2-H2-MHR Pre-Conceptual Design Report: HTE-Based Plant, GAA25402, General Atomics, Idaho National Laboratory, and Texas A\&M University, April 2006, http://www.osti.gov/energycitations/servlets/purl/883323-D3sgwx/883323.pdf.

7. General Atomics, Gas-Turbine Modular Helium Reactor (GT-MHR) Conceptual Design Description Report, GA Document No. 910720, Revision 1, July 1996, transmitted by letter from Laurence L. Parme (GA) to Raji Tripathi (USNRC), "GT-MHR Conceptual Design Description Report," GA/NRC-337-02, General Atomics, San Diego, CA, August 6, 2002, ADAMS Accession Number ML022470306,

http://adamswebsearch.nrc.gov/idmws/ViewDocByAccession.asp?AccessionNumber=ML02247 $\underline{0306 .}$

8. C. B. Baxi et al., Evolution of the Power Conversion Unit Design of the GT-MHR, GA-A25381, General Atomics, San Diego, CA, and Experimental Design Bureau of Machine Building, Nizhniy-Novgorod, Russian Federation, April 2006, https://fusion.gat.com/pubsext/MISCONF06/A25381.pdf.

9. Malcolm P. LeBar, The Gas Turbine-Modular Helium Reactor: A Promising Option for Near Term Deployment, GA-A23952, General Atomics, San Diego, CA, April 2002, presented as a paper at the 2002 International Congress on Advanced Nuclear Power Plants (ICAPP'02), Hollywood, Florida, June 9-13, 2002, order on CD at http://www.new.ans.org/store/i_700289. 
10. Section 3.8.2, "Gas-cooled Reactors-Transportation of Radioactive Materials," Section 5.7.2 +Gas-cooled Reactors-Uranium Fuel Cycle Impacts," and associated Attachments and Appendices on GT-MHR and PBMR, Early Site Permit Environmental Report Sections and Supporting Documentation, prepared for the United States Department of Energy, Office of Nuclear Energy, Science and Technology, for submission to the U.S. Nuclear Regulatory Commission, May 15,2003, ADAMS Accession Number ML040580285, http://adamswebsearch.nrc.gov/idmws/ViewDocByAccession.asp?AccessionNumber= ML040580285. (NOTE: Access to this site may sometimes require log-in as "guest.")

11. V. Petrunin et al., "Analysis of questions concerning the nonproliferation of fissile materials for low-and medium-capacity nuclear power systems," Atomnaya Energiya 105, Issue 3, pp. 123-127, September 2008 [in English. pp. 159-164, Atomic Energy 105, Springer, New York, ISSN 1063-4258 (Print), 1573-8205 (Online)].

12. NGNP Conceptual Design Studies-Reactor Building Design, Containment Issues, and Embedment Effects, Areva Document No. 12-9088427-001, September 2008, prepared under Battelle Energy Alliance Contract No. 00075310.

13. Brochure: AREVA HTR: A process heat source to power many industrial applications, http://www.areva-np.com/us/liblocal/docs/EPR/ANP_U-257_V1_06_ENG.pdf.

14. Brochure: ANTARES—The AREVA HTR-VHTR Design, http://www.areva-np.com/us/liblocal/docs/EPR/ANTARES.pdf

15. Kevin McCoy (AREVA NP Inc.), "Overview of Fuel and Materials Development for the AREVA HTR," 7th International Nuclear Graphite Specialists Meeting (INGSM-7), Oak Ridge, Tennessee, September 2006, Slide 5, "Typical ANTARES Operating Parameters," http://www.ms.ornl.gov/INGSM-7/papers/paper\%207.34.ppt\#264,6,Typical ANTARES Operating Parameters.

16. Philippe Billot (CEA) and Dominique Hittner (AREVA NP), "Outlines of the French R\&D Program for the development of High and Very High Temperature Reactor," Proceedings HTR2006: 3rd International Topical Meeting on High Temperature Reactor Technology, October 1-4, 2006, Johannesburg, South Africa, http://www.nwu.ac.za/htr2006/staticcontent/downloads/final_download_papers/a/A00000150.pdf.

17. Jean-Claude Gauthier et al., "ANTARES: The HTR/VHTR project at Framatome ANP," Paper No. A10, Proceedings of the Conference on High Temperature Reactors, Beijing, China, September, 22-24, 2004, International Atomic Energy Agency, Vienna (Austria), http://www.iaea.org/inisnkm/nkm/aws/htgr/fulltext/htr2004_a10.pdf. (NOTE: The data from this earlier document does not always agree with those given in Refs. 13 and 14 above.)

18. Dominique Greneche (Areva) and William J. Szymczak (Framatome ANP), "The AREVA HTR Fuel Cycle-An Overview of Technical Issues and Potential Industrial Solutions," Paper No. B02, Proceedings of the Conference on High Temperature Reactors, Beijing, China, September 22-24, 2004, International Atomic Energy Agency, Vienna (Austria), http://www.iaea.org/inisnkm/nkm/aws/htgr/fulltext/htr2004_b02.pdf.

19. K. Kunitome et al., "GTHTR300C for Hydrogen Cogeneration," Paper HTR2004-D18, 2nd International Topical Meeting on High Temperature Reactor Technology, Beijing, China, September 22-24, 2004, http://www.iaea.org/inisnkm/nkm/aws/htgr/fulltext/htr2004_d18.pdf.

20. K. Kunitome et al., "JAEA's VHTR for Hydrogen and Electricity Cogeneration: GTHTR300C," Nuclear Engineering and Technology 39, pp. 9-20, February 2007, http://article.nuclear.or.kr/jknsfile/v39/JK0390009.pdf. 
21. S. Shiozawa et al., "Overview of HTTR design features," Nuclear Engineering and Design 233, pp. 11-21, October 2004.

22. Jonghwa Chang et al., "A Study of a Nuclear Hydrogen Production Demonstration Plant," Nuclear Engineering and Technologies 39, pp. 111-122, April 2007, http://koixra1.kisti.re.kr/ra_resolution.jsp?koi=KISTI1.1003/JNL.JAKO200727543082171.

23. Chang Keun Jo, Hong Sik Lim, and Jae Man Noh, "Preconceptual Designs of the 200 MWth Prism and Pebble-bed Type VHTR Cores," PHYSOR-2008, International Conference on the Physics of Reactors "Nuclear Power: A Sustainable Resource," Casino-Kursaal Conference Center, Interlaken, Switzerland, September 14-19, 2008, abstract on page 270 at http://www.physor2008.ch/documents/Proceedings/physor08_Abstract_Vol1.pdf.

24. Jonghwa Chang and Won-Jae Lee, "Status of the Korean Nuclear Hydrogen Production Project," The 4th OECD/NEA Information Exchange Meeting on Nuclear Hydrogen Production, 14-16 April 2009, Chicago, Illinois (to be published by the Nuclear Energy Agency; not posted yet).

25. NGNP and Hydrogen Production Conceptual Design Study: Reactor Building Functional and Technical Requirements and Evaluation of Reactor Embedment, Westinghouse Electric Company Document No. NGNP-NHS100-RXBLDG, Revision 0, September 2008, prepared under contract to Battelle Energy Alliance.

26. Reactor Building Functional and Technical Requirements 90\% Design Review, Appendix A to Westinghouse Electric Company Document No. NGNP-NHS100-RXBLDG, Revision 0, September 2008, prepared under contract to Battelle Energy Alliance.

27. Presentations by PBMR (Pty) Ltd. to the U.S. Nuclear Regulatory Commission Public Meeting, PBMR Safety and Design Familiarization, February 28-March 3, 2006, http://adamswebsearch2.nrc.gov/idmws/ViewDocByAccession.asp?AccessionNumber=ML0606 50129. (NOTE: Access to this site may sometimes require log-in as "guest.")

28. Johan Slabber, PBMR (Pty) Ltd., "PBMR Nuclear Material Safeguards," Paper No. B14, Proceedings of the Conference on High Temperature Reactors, Beijing, China, September 2224, 2004, International Atomic Energy Agency, Vienna (Austria), http://www.iaea.org/inisnkm/nkm/aws/htgr/fulltext/htr2004_b14.pdf.

29. PBMR White Papers submitted to the U.S. Nuclear Regulatory Commission (USNRC) and retrievable from the USNRC's Agencywide Documents Access and Management System (ADAMS) (NOTE: Access to ADAMS may sometimes require log-in as "guest."):

a. "U.S. Design Certification, PRA Approach," June 13, 2006, ADAMS Accession Number ML061650404, http://adamswebsearch.nrc.gov/idmws/ViewDocByAccession.asp?AccessionNumber=ML06165 0404.

b. "U.S. Design Certification, Licensing Basis Event Selection for PBMR," July 3, 2006, ADAMS Accession Number ML061930123, http://adamswebsearch.nrc.gov/idmws/ViewDocByAccession.asp?AccessionNumber=ML06193 $\underline{0123}$.

c. "U.S. Design Certification, PBMR White Paper on Safety Classification of Structures, Systems, and Components," August 28, 2006, ADAMS Accession Number ML062400070, http://adamswebsearch.nrc.gov/idmws/ViewDocByAccession.asp?AccessionNumber=ML06240 0070 . 
d. "U.S. Design Certification, PBMR White Paper: Defense-in-Depth Approach," December 13, 2006, ADAMS Accession Number ML063470549,

http://adamswebsearch.nrc.gov/idmws/ViewDocByAccession.asp?AccessionNumber=ML06347 0549 .

e. "U.S. Design Certification, PBMR Fuel Performance Envelope and Test Program," October 2, 2007, ADAMS Accession Number ML080240094,

http://adamswebsearch.nrc.gov/idmws/ViewDocByAccession.asp?AccessionNumber=ML08024 0094.

f. "U.S. Design Certification, High-Temperature Materials-Metallics, Revision 1," April 24, 2008, ADAMS Accession Number ML081400680,

http://adamswebsearch.nrc.gov/idmws/ViewDocByAccession.asp?AccessionNumber=ML08140 0680 .

30. Z. Zhang and Y. Sun, "Economic Potential of Modular Reactor Nuclear Power Project Plants Based on the Chinese HTR-PM Project," Nuclear Engineering and Design 237, pp. 2265-2274, December 2007.

31. Z. Zhang et al., "Current status and technical description of Chinese $2 \times 250 \mathrm{MW}_{\text {th }}$ HTR-PM demonstration plant," Nuclear Engineering and Design 239, pp. 1212-1219, July 2009.

32. Y. Xu and K. Zuo, "Overview of the $10 \mathrm{MW}$ high temperature gas cooled reactor-test module project," Nuclear Engineering and Design 218, pp. 13-23, October 2002.

33. R. N. Morris et al., TRISO-Coated Particle Fuel Phenomenon Identification and Ranking Tables (PIRTs) for Fission Product Transport Due to Manufacturing, Operations, and Accidents, NUREG/CR-6844, Volumes 1-3, prepared for the U.S. Nuclear Regulatory Commission, Washington, D.C., July 2004, http://www.nrc.gov/reading-rm/doccollections/nuregs/contract/cr6844/.

34. S. J. Ball et al., Next Generation Nuclear Plant Phenomena Identification and Ranking Tables (PIRTs), NUREG/CR-6944 (ORNL/TM-2007/147), Volumes 1-6, prepared for the U.S. Nuclear Regulatory Commission, Oak Ridge National Laboratory, Oak Ridge, TN, March 2008, http://www.nrc.gov/reading-rm/doc-collections/nuregs/contract/cr6944/.

35. P. M. Williams, T. L. King, and J. N. Wilson, Draft Preapplication Safety Evaluation Report for the Modular High-Temperature Gas-Cooled Reactor, NUREG-1338, Office of Nuclear Regulatory Research, U.S. Nuclear Regulatory Commission, Washington, D.C., March 1989, ADAMS Accession Number ML052780497, http://adamswebsearch.nrc.gov/idmws/ViewDocByAccession.asp?AccessionNumber=ML05278 0497. (NOTE: Access to this site may sometimes require log-in as "guest.")

36. Preapplication Safety Evaluation Report for the Modular High-Temperature Gas-Cooled Reactor (MHTGR), NUREG-1338, Office of Nuclear Reactor Regulation, U.S. Nuclear Regulatory Commission, Washington, D.C., December 1995, ADAMS Accession Number ML052780519, http://adamswebsearch.nrc.gov/idmws/ViewDocByAccession.asp?AccessionNumber=ML05278 0519. [NOTE: Access to this site may sometimes require log-in as "guest."]

37. S. J. Ball et al., Next Generation Nuclear Plant GAP Analysis Report, ORNL/TM-2007/228, Oak Ridge National Laboratory, Oak Ridge, TN, July 2008, http://apps.ornl.gov/ pts/prod/pubs/ldoc9418_gap_final_20080715.pdf.

38. Chris Ellis, Alan Baxter, and Arkal Shenoy, "Modular Helium Reactor Fuel Cycle Concepts and Sustainability," Paper No. B25, Proceedings of the Conference on High Temperature Reactors, 
Beijing, China, September 22-24, 2004, International Atomic Energy Agency, Vienna (Austria), http://www.iaea.org/inisnkm/nkm/aws/htgr/fulltext/htr2004_b25.pdf.

39. Igor M. Kadarmetov et al., "The Bench-Scale Facility for Fabrication of TRISO-Coated Plutonium Fuels," Paper No. HTR2008-58319, Proceedings of the 4th International Topical Meeting on High Temperature Technology, HTR2008, September 28-October 1, 2008, Washington, D.C., USA, available for purchase through the ASME Product Catalog at http://catalog.asme.org/ConferencePublications/PrintBook/2008_Proceedings_4th.cfm.

40. B. Bonin et al., "Prospective Studies of HTR Fuel Cycles Involving Plutonium," HTR-2002: Proceedings of the Conference on High Temperature Reactors, Petten, The Netherlands, April 22-24, 2002, http://www.iaea.org/inisnkm/nkm/aws/htgr/fulltext/htr2002_205.pdf.

41. Dominique Greneche, "HTR fuel cycles: A comprehensive outlook of past experience and an analysis of future options," 2003 International Congress on Advances in Nuclear Power Plants (ICAPP '03), May 4-7, 2003, Congress Palais, Córdoba, Spain, abstract at http://icapp.ans.org/icapp03/program/abstracts/3095.pdf and available for purchase on proceedings CD at http://www.new.ans.org/store/i_700301.

42. Bernard Bonin et al., "Utilization/Disposition of Reactor-Grade Plutonium in High-Temperature Gas-Cooled Reactors," Nuclear Technology 145, No. 3, pp. 266-274, March 2004, available for purchase at http://www.new.ans.org/pubs/journals/nt/a_3476.

43. Dominique Greneche et al., "Rethinking the Thorium Fuel Cycle: An Industrial Point of View," Paper 7367, 2007 International Congress on Advances in Nuclear Power Plants (ICAPP '07), Nice, France, May 13-18, 2007, http://www.torium.se/res/Documents/7367.pdf.

44. Standard Review Plan for the Review of Safety Analysis Reports for Nuclear Power Plants, NUREG-0800, Revision 6 or by section number as applicable, U.S. Nuclear Regulatory Commission, Washington, D.C., March 2007, http://www.nrc.gov/reading-rm/doccollections/nuregs/staff/sr0800/.

45. Rules and Regulations of the Russian Federal Service for Ecological, Technical and Atomic Supervision (Rostekhnadzor), not available on line.

46. State Standards of the Russian Federation ("gosudartsvennye standarty" or GOSTy or GOST), http://www.eastview.com/Books/RussianStandards/Browse.aspx and available for purchase at http://www.russiangost.com/c-127-gost.aspx.

47. A. L. Lotts et al., Options for Treating High-Temperature Gas-Cooled Reactor Fuel for Repository Disposal, ORNL/TM-12077, Oak Ridge National Laboratory, Oak Ridge, TN, February 1992, http://www.osti.gov/energycitations/servlets/purl/10147826-UOgnfy/ and http://www.osti.gov/energycitations/servlets/purl/5350512-fXloNS/.

48. Charles W. Forsberg et al., "A New Repository Waste Form: Graphite-Carbon High-Level Waste (HTGR Fuel Processing and Waste Forms)," American Nuclear Society 2003 International High-Level Radioactive Waste Management Conference, Las Vegas, $N$, March 30-April 2, 2003, http://www.ornl.gov/ webworks/cppr/y2001/pres/116773.pdf.

49. G. D. DelCul et al., TRISO-Coated Fuel Processing to Support High-Temperature Gas-Cooled Reactors, ORNL/TM-2002/156, Oak Ridge National Laboratory, Oak Ridge, TN, September 2002, http://www.ornl.gov/ webworks/cppr/y2003/rpt/114586.pdf.

50. C. L. Bendixsen et al., Development and engineering plan for graphite spent fuels conditioning program, WINCO-1150, Westinghouse Idaho Nuclear Co., Inc., Idaho Falls, ID, September 1, 1993, http://www.osti.gov/energycitations/servlets/purl/142482-gEIPx1/native/. 
51. S. M. Berry, Fort St. Vrain graphite fuel mechanical separation concept selection. Final report, WINCO-1159, Westinghouse Idaho Nuclear Co., Inc., Idaho Falls, ID, September 1, 1993, http://www.osti.gov/energycitations/servlets/purl/10157688-fjkxRu/native/.

52. D. L. Lord et al., Conceptual design report for the mechanical disassembly of Fort St. Vrain fuel elements, WINCO-1170, Westinghouse Idaho Nuclear Co., Inc., Idaho Falls, ID, September 1, 1993, http://www.osti.gov/energycitations/servlets/purl/142534-Famr1x/native/142534.pdf.

53. R. A. Gavalya, Conceptual design report for handling Fort St. Vrain fuel element components, WINCO-1178, Westinghouse Idaho Nuclear Co., Inc., Idaho Falls, ID, September 1, 1993, http://www.osti.gov/energycitations/servlets/purl/142488-3pdhex/142488.pdf.

54. R. E. Lords and R. J. Kirkham, Graphite fuels combustion off-gas treatment options, WINCO1209 (formerly WIN-306-Rev.1), Westinghouse Idaho Nuclear Co., Inc., Idaho Falls, ID, March 1, 1993, http://www.osti.gov/energycitations/servlets/purl/10158870-

1N3Hya/native/10158870.pdf.

55. A. P. Pinto, Disposal options for burner ash from spent graphite fuel: Final study report November 1993, WINCO-1223, Westinghouse Idaho Nuclear Co., Inc., Idaho Falls, ID, http://www.osti.gov/energycitations/servlets/purl/10183175-HbsycB/native/10183175.pdf.

56 S. C. Marschman et al., Characterization Plan for Fort St. Vrain and Peach Bottom Graphite Fuels, PNNL-11365, Pacific Northwest National Laboratory, Richland, WA, September 1993, http://www.osti.gov/energycitations/servlets/purl/414255-PeNpG2/webviewable/414255.pdf.

57. Mitsuru Maeda and Eiji Yagi, Feasibility Study for Removal of SiC Coating in HTGR-type Fuel by $F_{2}$-Fluorination, JAERI-M-7060, Japan Atomic Energy Research Institute, Tokai, Japan, April 1977, http://jolissrch-inter.tokai-sc.jaea.go.jp/pdfdata/JAERI-M-7060.pdf.

58. M. A. Fütterer, H. Bluhm, P. Hoppé, and J. Singer, Head-End Process for the Reprocessing of Reactor Core Material, International Patent WO/2006/087360, European Patent EP1849164, publication date 24 August 2006, http://www.wipo.int/pctdb/en/wo.jsp?wo=2006087360.

59. A. M. Ougouag, H. D. Gougar, and T. A. Todd, Evaluation of the Strategic Value of Fully Burnt PBMR Spent Fuel, INL/EXT-06-11272, Idaho National Laboratory, Idaho Falls, ID, May 2006, http://www.inl.gov/technicalpublications/Documents/3372140.pdf.

60. Andrew C Kadak, "Modular Pebble Bed Reactor High Temperature Gas Reactor," presentation at the American Nuclear Society, Winter Meeting-Washington, D.C., November 2002, http://web.mit.edu/pebble-bed/Presentation/MPBRHTGR.pdf.

61. Andrew C. Kadak, "Chinese Research on Future Nuclear Energy Systems," 14th International Security Conference: Strengthening the Nuclear Nonproliferation Regime Focus on the Civilian Nuclear Fuel Cycle, April 6, 2005, http://www.intlsecconf.sandia.gov/kadak_05isc.pdf.

62. A. M. Ougouag, W. K. Terry, and H. D. Gougar, "Examination of the Potential for Diversion or Clandestine Dual Use of a Pebble-Bed reactor to produce Plutonium," Paper No. 206, HTR-

2002: Proceedings of the Conference on High Temperature Reactors, Petten, The Netherlands, April 22-24, 2002, http://www.iaea.org/inisnkm/nkm/aws/htgr/fulltext/htr2002_206.pdf.

63. William K. Terry (Ed.), Modular Pebble-Bed Reactor Project: Laboratory-Directed Research and Development Program FY 2001 Annual report, INEEL/EXT-01-01623, Idaho National Engineering and Environmental laboratory, Idaho Fall, ID, and The Massachusetts Institute of Technology, Cambridge, MA, December 2001, http://web.mit.edu/pebblebed/PBRLDRDreport2001.pdf.

64. Charles W. Forsberg and David L. Moses, Safeguards Challenges for Pebble-Bed Reactors (PBRs): Peoples Republic of China (PRC), ORNL/TM-2008/229, Oak Ridge National 
Laboratory, Oak Ridge, TN, November 2009, http://info.ornl.gov/sites/publications/files/Pub13759.pdf.

65. L. S. Abbott, D. E. Bartine, and T. J. Burns (Eds.), Interim Assessment of the Denatured ${ }^{233} U$ Fuel Cycle: Feasibility and Nonproliferation Characteristics, Revision 1, ORNL-5388/R1, Oak Ridge National Laboratory, Oak Ridge, TN, December 1979, http://www.ornl.gov/info/reports/1979/3445605995392.pdf.

66. C. W. Forsberg, C. M. Hopper, and H. C. Vantine, "What is nonweapons-usable ${ }^{233}$ U?," Transactions of the American Nuclear Society 81, pp. 62-63, American Nuclear Society 1999 Winter Meeting, Long Beach, CA, November 14-18, 1999, July 1, 1999.

67. The Design of Gas-Cooled Graphite-Moderated Reactors, D. R. Poulter ( Ed.), Oxford University Press, New York, 1963.

68. Nuclear Graphite, R. E. Nightingale (Ed.), Academic Press, New York, 1962.

69. C. D. Riendeau, D. L. Moses, and A. P. Olsen, Proliferation Potential of Accelerator-Driven Systems: Feasibility Calculations, K/NSP-778, Lockheed-Martin Energy Systems, Oak Ridge, TN, November 1, 1998, http://www.osti.gov/energycitations/servlets/purl/12464s1ZzJe/webviewable/12464.pdf.

70. IAEA SAFEGUARDS GLOSSARY, 2001 Edition, INTERNATIONAL NUCLEAR VERIFICATION SERIES No. 3, International Atomic Energy Agency, Vienna (Austria), http://www-pub.iaea.org/MTCD/publications/PDF/nvs-3-cd/PDF/NVS3_prn.pdf.

71. The Agency's Safeguards System (1965, as Provisionally Extended in 1966 and 1968). INFCIRC/66/Rev.2, International Atomic Energy Agency, Vienna (Austria), September 16, 1968, http://www.iaea.org/Publications/Documents/Infcircs/Others/inf66r2.shtml.

72. The Structure and Content of Agreements between the Agency and States Required in Connection with the Treaty on the Non-Proliferation of Nuclear Weapons, INFCIRC/153 (Corrected), International Atomic Energy Agency, Vienna (Austria), June 1972, http://www.iaea.org/Publications/Documents/Infcircs/Others/infcirc153.pdf,

73. Model Protocol Additional to the Agreement(s) between the State(s) and the International Atomic Energy Agency for the Application of Safeguards, INFCIRC/540 (Corrected), International Atomic Energy, Vienna (Austria), September 1997, http://www.iaea.org/Publications/Documents/Infcircs/1997/infcirc540.pdf.

74. J. E. Cunningham and R. E. Adams, "Techniques for Canning and Bonding Metallic Uranium with Aluminum," pp. 102-119, Fuels Elements Conference, Paris, November 18-23, 1957, TID7546, Volume 1, Commissariat a l'Energie Atomique, Paris, France, and U.S. Atomic Energy Commission, Washington, D.C., http://www.osti.gov/energycitations/servlets/purl/4346314TuwNpI/native/4346314.pdf.

75. Nuclear reactor fuel elements: metallurgy and fabrication (Prepared under the auspices of the Division of Technical Information, United States Atomic Energy Commission), Albert R. Kaufmann (Ed.), Interscience Publishers, New York, 1962, available to read page-by-page as image files at http://babel.hathitrust.org/cgi/pt?id=mdp.39015003995118.

76. A. Fernandez, D. Haas, and J. Somers, "Fabrication of Plutonium Based Coated Particle Fuel at the Institute for Transuranium Elements," Paper No. HTR2006-B98, Proceedings HTR2006: 3rd International Topical Meeting on High Temperature Reactor Technology October 1-4, 2006, Johannesburg, South Africa, http://www.nwu.ac.za/htr2006/staticcontent/downloads/final_download_papers/b/B00000098.pdf. 
77. J. E. Selle, Chemical and Physical Considerations of the Use of Nuclear Fuel Spikants for Deterrence, ORNL/TM-6412, Oak Ridge National Laboratory, Oak Ridge, TN, October 1978, http://www.ornl.gov/info/reports/1978/3445605514468.pdf.

78. J. E. Selle et al., Practical Consideration of Nuclear Fuel Spiking for Proliferation Deterrence, ORNL/TM-6483, Oak Ridge National Laboratory, Oak Ridge, TN, October 1978, http://www.ornl.gov/info/reports/1978/3445605514823.pdf.

79. L. H. Brooks, The use of spikants in HTGR fuel and their effect on costs, GA-A15377, General Atomic Company, San Diego, CA, May 1979, http://www.osti.gov/energycitations/servlets/purl/6110547-EDceNa/6110547.pdf.

80. W. H. Pechin et al., Inspection of High-Temperature Gas-Cooled Reactor Recycle Fuel, ORNL5165, Oak Ridge National Laboratory, Oak Ridge, TN, June 1977, http://www.ornl.gov/info/reports/1977/3445605159351.pdf.

81. T. W. Eichenberg et al., Continuous Improvement of the MHTGR Safety and Competitive Performance, GA-A20884 (CONF-920818-3), General Atomics, San Diego, CA, http://www.osti.gov/energycitations/servlets/purl/5176407-MuOHqj/5176407.pdf.

82. Reference Modular High Temperature Gas-Cooled Reactor Plant: Concept description report, DOE/HTGR-86-118, Bechtel National, Inc., San Francisco, CA, October 1986. (Scan and upload requested from DOE OSTI.)

83. Preliminary Safety Information Document for the Standard MHTGR, DOE/HTGR-86-024, Volumes 1-5, Stone \& Webster Engineering Corp., Boston, MA, December 1986 updated through February 1989, Volume 1 at http://www.osti.gov/energycitations/servlets/purl/712676sfXuja/native/712676.pdf. (Scan and upload for Volumes 2-5 requested from DOE OSTI.) 


\section{APPENDIX A VHTR MAJOR REACTOR DESIGN PARAMETERS}



Table A.1. VHTR major reactor design parameters

\begin{tabular}{|c|c|c|c|c|c|c|c|}
\hline $\begin{array}{c}\text { Major Reactor } \\
\text { Parameters }\end{array}$ & $\begin{array}{c}\text { Areva Modular } \\
\text { HTR }\end{array}$ & $\begin{array}{c}\text { General } \\
\text { Atomics } \\
\text { GT-MHR }\end{array}$ & $\begin{array}{c}\text { Westinghouse \& } \\
\text { PBMR (Pty) Ltd. } \\
\text { PBMR }\end{array}$ & $\begin{array}{c}\text { Huaneng } \\
\text { Group \& } \\
\text { CNEC/INET } \\
\text { HTR-PM }\end{array}$ & $\begin{array}{c}\text { JAEA } \\
\text { GTHTR300C }\end{array}$ & $\begin{array}{c}\text { OKBM } \\
\text { GT-MHR }\end{array}$ & $\begin{array}{l}\text { KAERI } \\
\text { NHDD }\end{array}$ \\
\hline $\begin{array}{l}\text { Thermal power } \\
\text { (MW-th) }\end{array}$ & 600 & 600 & 400 & 250 & 600 & 600 & 200 \\
\hline $\begin{array}{l}\text { Thermal efficiency } \\
(\%) \text { in electricity } \\
\text { generation }\end{array}$ & $\sim 50$ (inferred) & $\sim 48$ & $\begin{array}{l}44.8 \text { at a core } \\
\text { coolant } \mathrm{T}_{\text {outlet }} \text { of } \\
\sim 850^{\circ} \mathrm{C}\end{array}$ & 40 & 50 (inferred) & $\sim 48$ & $\begin{array}{l}\text { None, } \mathrm{H}_{2} \\
\text { production }\end{array}$ \\
\hline Primary coolant & Helium & Helium & Helium & Helium & Helium & Helium & Helium \\
\hline Moderator & $\begin{array}{l}\text { High- } \\
\text { Temperature } \\
\text { Graphite }\end{array}$ & $\begin{array}{l}\text { High- } \\
\text { Temperature } \\
\text { Graphite }\end{array}$ & $\begin{array}{l}\text { High-Temperature } \\
\text { Graphitized } \\
\text { Carbon with } \\
\text { Graphite Reflector }\end{array}$ & $\begin{array}{l}\text { High- } \\
\text { Temperature } \\
\text { Graphitized } \\
\text { Carbon with } \\
\text { Graphite } \\
\text { Reflector }\end{array}$ & $\begin{array}{l}\text { High- } \\
\text { Temperature } \\
\text { Graphite }\end{array}$ & $\begin{array}{l}\text { High- } \\
\text { Temperature } \\
\text { Graphite }\end{array}$ & $\begin{array}{l}\text { High- } \\
\text { Temperature } \\
\text { Graphite or } \\
\text { Graphitized } \\
\text { Carbon with } \\
\text { Reflector }\end{array}$ \\
\hline $\begin{array}{l}\text { Power density } \\
\left(\mathrm{MW} / \mathrm{m}^{3}\right)\end{array}$ & $\sim 6.3$ (inferred) & 6.3 & 4.78 & $\sim 3.22$ & 5.4 & 6.3 & $\begin{array}{l}2.27-3.0 \\
\text { pebble, } 5.68 \\
\text { prismatic }\end{array}$ \\
\hline Fuel materials & $\begin{array}{l}\mathrm{LEUO}_{2} \text { TRISO- } \\
\text { coated particles }\end{array}$ & $\begin{array}{l}\mathrm{UC}_{0.5} \mathrm{O}_{1.5} \\
\text { TRISO-coated } \\
\text { particles; } \\
\mathrm{LEUC}_{0.5} \mathrm{O}_{1.5} \\
(19.8 \%) \text { fissile } \\
\text { and } \\
\mathrm{U}_{\text {Nat }} \mathrm{C}_{0.5} \mathrm{O}_{1.5} \\
\text { fertile }\end{array}$ & $\begin{array}{l}\mathrm{LEUO}_{2} \text { TRISO- } \\
\text { coated particles }\end{array}$ & $\begin{array}{l}\mathrm{LEUO}_{2} \\
\text { TRISO-coated } \\
\text { particles }\end{array}$ & $\begin{array}{l}\mathrm{LEUO}_{2} \\
\text { TRISO-coated } \\
\text { particles }\end{array}$ & $\begin{array}{l}\mathrm{PuO}_{1.8} \\
\mathrm{LEUCO} \\
\text { mixed } \\
\text { uranium- } \\
\text { plutonium } \\
\text { oxide (MOX) }\end{array}$ & $\begin{array}{l}\mathrm{LEUO}_{2} \\
\text { TRISO-coated } \\
\text { particles }\end{array}$ \\
\hline
\end{tabular}


Table A.1. (continued)

\begin{tabular}{|c|c|c|c|c|c|c|c|}
\hline $\begin{array}{c}\text { Major reactor } \\
\text { parameters }\end{array}$ & $\begin{array}{c}\text { Areva Modular } \\
\text { HTR }\end{array}$ & $\begin{array}{c}\text { General } \\
\text { Atomics } \\
\text { GT-MHR }\end{array}$ & $\begin{array}{c}\text { Westinghouse \& } \\
\text { PBMR (Pty) Ltd. } \\
\text { PBMR }\end{array}$ & $\begin{array}{c}\text { Huaneng } \\
\text { Group \& } \\
\text { CNEC/INET } \\
\text { HTR-PM }\end{array}$ & $\begin{array}{c}\text { JAEA } \\
\text { GTHTR300C }\end{array}$ & $\begin{array}{c}\text { OKBM } \\
\text { GT-MHR }\end{array}$ & $\begin{array}{l}\text { KAERI } \\
\text { NHDD }\end{array}$ \\
\hline $\begin{array}{l}\text { Core inlet } \\
\text { temperature/pressure } \\
\left({ }^{\circ} \mathrm{C} / \mathrm{MPa}\right)\end{array}$ & $\begin{array}{l}500 / \sim 6.0-7.0 \\
\text { (pressure inferred) }\end{array}$ & $490 / 7.07$ & $\begin{array}{l}500 / \sim 9.0 \\
\text { (pressure inferred) }\end{array}$ & $250 / \sim 7.0$ & $\begin{array}{l}586-663 / 6.9 \\
\text { (electrical } \\
\text { production) \& } \\
594 / 5.1\left(\mathrm{H}_{2}\right. \\
\text { production) }\end{array}$ & $490 / 7.07$ & $490 / \sim 7.0$ \\
\hline $\begin{array}{l}\text { Core outlet } \\
\text { temperature/pressure } \\
\left({ }^{\circ} \mathrm{C} / \mathrm{MPa}\right)\end{array}$ & $\begin{array}{l}900-1000 \text { (for } \mathrm{H}_{2} \\
\text { production/ } 6.0 \text { or } \\
850 \text { (for electricity } \\
\text { generation)/7.0 }\end{array}$ & $850 / 7.0$ & $900 / \sim 9.0$ & $750 / \sim 7.0$ & $\begin{array}{l}850-950 / 6.9 \\
\text { (electrical } \\
\text { production) \& } \\
950 / 5.1\left(\mathrm{H}_{2}\right. \\
\text { production) }\end{array}$ & $850 / 7.0$ & $950 / \sim 7.0$ \\
\hline $\begin{array}{l}\text { Neutron energy } \\
\text { spectrum }\end{array}$ & $\begin{array}{l}\text { Thermal peaking } \\
\text { just below } 0.3 \mathrm{eV}\end{array}$ & $\begin{array}{l}\text { Thermal } \\
\text { peaking just } \\
\text { below } 0.3 \mathrm{eV}\end{array}$ & $\begin{array}{l}\text { Thermal peaking } \\
\text { just below } 0.3 \mathrm{eV}\end{array}$ & $\begin{array}{l}\text { Thermal } \\
\text { peaking just } \\
\text { below } 0.3 \mathrm{eV}\end{array}$ & $\begin{array}{l}\text { Thermal } \\
\text { peaking just } \\
\text { below } 0.3 \mathrm{eV}\end{array}$ & $\begin{array}{l}\text { Thermal } \\
\text { peaking just } \\
\text { below } 0.3 \mathrm{eV}\end{array}$ & $\begin{array}{l}\text { Thermal } \\
\text { peaking just } \\
\text { below } 0.3 \mathrm{eV}\end{array}$ \\
\hline
\end{tabular}




\section{APPENDIX B A COMPARISON OF VHTR FUEL CYCLE PARAMETERS}



Table B.1. A comparison of VHTR fuel cycle parameters

\begin{tabular}{|c|c|c|c|c|c|c|c|}
\hline $\begin{array}{l}\text { Fuel cycle } \\
\text { parameters }\end{array}$ & $\begin{array}{c}\text { Areva } \\
\text { Modular HTR }\end{array}$ & $\begin{array}{c}\text { General } \\
\text { Atomics } \\
\text { GT-MHR }\end{array}$ & $\begin{array}{c}\text { Westinghouse/ } \\
\text { PBMR (Pty) Ltd. } \\
\text { PBMR }\end{array}$ & $\begin{array}{c}\text { Huaneng } \\
\text { Group \& } \\
\text { CNEC/ } \\
\text { INET } \\
\text { HTR-PM } \\
\end{array}$ & $\begin{array}{c}\text { JAEA } \\
\text { GTHTR300C }\end{array}$ & $\begin{array}{c}\text { OKBM } \\
\text { GT-MHR }\end{array}$ & $\begin{array}{l}\text { KAERI } \\
\text { NHDD }\end{array}$ \\
\hline $\begin{array}{l}\text { Reactor thermal } \\
\text { power } \\
\text { (MW-th) }\end{array}$ & 600 & 600 & 400 & 250 & 600 & 600 & 200 \\
\hline $\begin{array}{l}\text { Reactor electrical } \\
\text { power (MWe) } \\
\text { Generation }\end{array}$ & $\begin{array}{l}\text { 300, } 186 \text { for } \\
\text { cogeneration } \\
\text { with process } \\
\text { heat use }\end{array}$ & $\begin{array}{l}262 \text { to } 286 \\
\text { (varied } \\
\text { assumptions } \\
\text { documented) }\end{array}$ & 165 & $\begin{array}{l}100 \text { per reactor } \\
\text { in two reactors } \\
\text { per module }\end{array}$ & $\begin{array}{l}274-300 \\
\text { depending on } \\
\text { outlet } \mathrm{T}, \\
87-202 \\
\text { depending on } \\
\mathrm{H}_{2} \text { production }\end{array}$ & $\begin{array}{l}262 \text { to } 286 \\
\text { (varied } \\
\text { assumptions } \\
\text { documented) }\end{array}$ & $\begin{array}{l}\text { Only } \mathrm{H}_{2} \\
\text { production }\end{array}$ \\
\hline $\begin{array}{l}\text { Fuel type } \\
\text { - Form }\end{array}$ & $\begin{array}{l}\text { LEU } \\
- \text { Ceramic } \\
\text { coated } \\
\text { particle }\end{array}$ & $\begin{array}{l}\text { LEU } \\
\qquad \begin{array}{l}\text { Ceramic } \\
\text { coated } \\
\text { particle }\end{array}\end{array}$ & $\begin{array}{l}\text { LEU } \\
\text { - Ceramic } \\
\quad \text { coated particle }\end{array}$ & $\begin{array}{l}\text { LEU } \\
- \text { Ceramic } \\
\text { coated } \\
\text { particle }\end{array}$ & $\begin{array}{l}\text { LEU } \\
\text { - Ceramic } \\
\text { coated } \\
\text { particle }\end{array}$ & $\begin{array}{c}\text { Pu initially } \\
\text { - Ceramic } \\
\text { coated } \\
\text { particle }\end{array}$ & $\begin{array}{l}\text { LEU } \\
- \text { Ceramic } \\
\text { coated particle }\end{array}$ \\
\hline $\begin{array}{l}- \text { Fertile } \\
\text { material }\end{array}$ & & & & & & & \\
\hline $\begin{array}{l}\text { - Fissile } \\
\text { material }\end{array}$ & $-{ }^{235} \mathrm{U}$ & $-{ }^{235} \mathrm{U}$ & $-{ }^{235} \mathrm{U}$ & $-{ }^{235} \mathrm{U}$ & $-{ }^{235} \mathrm{U}$ & $-\mathrm{Pu}$ & $-{ }^{235} \mathrm{U}$ \\
\hline Enrichment (\%) & $\sim 15$ & $\begin{array}{l}19.8 \text { in fissile } \\
\text { particles, } 0.7 \\
\left(U_{\text {Nat }}\right) \text { in fertile } \\
\text { particles }\end{array}$ & $\begin{array}{l}9.6 \text { in the } \\
\text { equilibrium core } \\
\text { loading } \sim 5.7 \text { in } \\
\text { start-up loading }\end{array}$ & $\begin{array}{l}8.5 \text { in the } \\
\text { equilibrium } \\
\text { core }\end{array}$ & $\sim 14$ & Pure Pu & $\begin{array}{l}9.6 \text { pebble, } \\
15.5 \text { prismatic }\end{array}$ \\
\hline $\begin{array}{l}\text { Source of fissile } \\
\text { material (inputs } \\
\text { are assumed } \\
\text { since not given } \\
\text { in available } \\
\text { documentation) }\end{array}$ & $\begin{array}{l}\text { U.S. or } \\
\text { European } \\
\text { enrichment } \\
\text { plants } \\
\text { (inferred) }\end{array}$ & $\begin{array}{l}\text { U.S. or } \\
\text { European } \\
\text { enrichment } \\
\text { plants } \\
\text { (inferred) }\end{array}$ & $\begin{array}{l}\text { South African, } \\
\text { U.S. or European } \\
\text { enrichment } \\
\text { plants (inferred) }\end{array}$ & Undefined & Undefined & $\begin{array}{l}\text { Russian excess } \\
\text { weapons Pu; } \\
\text { other U and } \\
\text { Pu in later } \\
\text { versions }\end{array}$ & Undefined \\
\hline $\begin{array}{l}\text { Fuel inventory } \\
\text { (MT) }\end{array}$ & Not given & $\begin{array}{l}4.68 \text { initial core, } \\
2.26 \text { each } \\
\text { reload }\end{array}$ & $\begin{array}{l}\sim 4.0 \text { in } \\
\text { equilibrium core }\end{array}$ & $\begin{array}{l}2.9 \text { in } \\
\text { equilibrium } \\
\text { core }\end{array}$ & Not given & $\begin{array}{l}\sim 1.8 \text { in } \\
\text { equilibrium } \\
\text { cycle }\end{array}$ & Not given \\
\hline
\end{tabular}


Table B.1. (continued)

\begin{tabular}{|c|l|l|l|l|l|l|l|}
\hline $\begin{array}{c}\text { Fuel cycle } \\
\text { parameters }\end{array}$ & $\begin{array}{c}\text { Areva Modular } \\
\text { HTR }\end{array}$ & $\begin{array}{c}\text { General } \\
\text { Atomics } \\
\text { GT-MHR }\end{array}$ & $\begin{array}{c}\text { Westinghouse/ } \\
\text { PBMR (Pty) } \\
\text { Ltd. PBMR }\end{array}$ & $\begin{array}{c}\text { Huaneng } \\
\text { Group \& } \\
\text { CNEC/ } \\
\text { INET HTR-PM }\end{array}$ & $\begin{array}{c}\text { JAEA } \\
\text { GTHTR300C }\end{array}$ & $\begin{array}{c}\text { OKBM } \\
\text { GT-MHR }\end{array}$ & $\begin{array}{c}\text { KAERI } \\
\text { NHDD }\end{array}$ \\
\hline $\begin{array}{c}\text { Discharge burn- } \\
\text { up (GWD/MT) }\end{array}$ & 150 & $\begin{array}{c}121 \text { for LEU } \\
\text { cycle }\end{array}$ & 91 & 90 & 120 & $\sim 120-150$ & 153 \\
\hline $\begin{array}{c}\text { Refueling } \\
\text { frequency } \\
\text { (months) }\end{array}$ & 18 & $\begin{array}{c}\text { Continuous on } \\
\text { line }\end{array}$ & $\begin{array}{l}\text { Continuous on } \\
\text { line }\end{array}$ & $\begin{array}{l}24(\text { electrical)/ } \\
18\left(\mathrm{H}_{2}\right)\end{array}$ & 18 & Pebble continuous; \\
\hline $\begin{array}{c}\text { Recycle } \\
\text { approach }\end{array}$ & $\begin{array}{c}\text { Baseline is once- } \\
\text { through }\end{array}$ & $\begin{array}{l}\text { Baseline is once- } \\
\text { through }\end{array}$ & $\begin{array}{c}\text { Baseline is once- } \\
\text { through }\end{array}$ & $\begin{array}{l}\text { Baseline is once- } \\
\text { through }\end{array}$ & $\begin{array}{l}\text { Baseline is once- } \\
\text { through }\end{array}$ & $\begin{array}{c}\text { No recycle, } \\
\text { deep-burn }\end{array}$ & $\begin{array}{c}\text { Baseline is once- } \\
\text { through }\end{array}$ \\
\hline $\begin{array}{c}\text { Recycle } \\
\text { technology }\end{array}$ & To be developed & To be developed & $\begin{array}{l}\text { To be developed } \\
\text { To be developed }\end{array}$ & $\begin{array}{l}\text { To be developed } \\
\text { No recycle, } \\
\text { deep-burn }\end{array}$ & To be developed \\
\hline $\begin{array}{c}\text { Recycle } \\
\text { efficiency }\end{array}$ & $\begin{array}{c}\text { To be } \\
\text { determined }\end{array}$ & $\begin{array}{c}\text { To be } \\
\text { determined }\end{array}$ & $\begin{array}{c}\text { To be } \\
\text { determined }\end{array}$ & $\begin{array}{c}\text { To be } \\
\text { determined }\end{array}$ & $\begin{array}{c}\text { To be } \\
\text { determined }\end{array}$ & $\begin{array}{c}\text { No recycle, } \\
\text { deep-burn }\end{array}$ & To be determined \\
\hline
\end{tabular}




\section{APPENDIX C \\ TECHNICAL HISTORY REVIEW OF HTGR SPENT FUEL DISPOSAL, REPROCESSING, AND RECYCLE/REFABRICATION TECHNOLOGIES}





\section{APPENDIX C. TECHNICAL HISTORY REVIEW OF HTGR SPENT FUEL DISPOSAL, REPROCESSING, AND RECYCLE/REFABRICATION TECHNOLOGIES}

\section{C.1 INTRODUCTION}

In the 1960s and 1970s, most of the research and development on sustainable fuel cycles for the High-Temperature Gas-cooled Reactor (HTGR) was performed for the high enriched uranium/thorium (HEU/Th) fuel cycle with ${ }^{233} \mathrm{U}$ recycle or for the utilization of recycled plutonium from other reactor spent fuel as fissile fuel in the HTGR. The majority of this work took place in either (1) the Organization for Economic Cooperation and Development (OECD) Dragon Project led by the Atomic Energy Establishment (A.E.E.) laboratories in the United Kingdom; (2) the contemporaneous Arbeitsgemeinschaft Versuchs-Reaktor (AVR) at the Jülich Nuclear Research Center (KFA-Jülich) in the Federal Republic of Germany built in cooperation with the Brown-BoveriCie-Krupp construction concern and developed in cooperation both with the OECD Dragon Project and under the United States-Federal Republic of Germany High-Temperature Reactor Research Exchange Program; or (3) the U.S. Atomic Energy Commission (AEC) programs led by Oak Ridge National Laboratory (ORNL) and General Atomic (GA) Company in the United States with key support on reprocessing implementation by the Idaho Chemical Processing Plant (ICPP) in Idaho Falls . The U.S. AEC programs included both the Gas-Cooled Reactor (GCR) Program and the Thorium Utilization Program that later merged into a single program in 1970. Prior to the 1950s in the mid-1940s, early work on reprocessing technologies for graphite-based fuels had been initiated by the U.S. AEC as part of the High-Temperature Power Pile Program conducted in cooperation of the University of Chicago Metallurgical Laboratory and the Clinton Laboratories in Oak Ridge.

In addition, between 1953 and 1972, the U.S. AEC funded research, development, fabrication and testing work by Los Alamos National Laboratory (LANL) and the Y-12 Plant in Oak Ridge on HEUfueled, graphite-moderated nuclear space rockets (KIWI, ROVER/NERVA, see http://www.fas.org/nuke/space/c04rover.htm) that were fueled with HEU carbide and had the graphite around the rocket cooling holes coated with either zirconium carbide or niobium carbide to resist erosion and fuel failure when hydrogen was fired through the reactor as the propellant. In the same period, there was extensive work at both ORNL and the ICPP to develop methods for recovering the HEU from the KIWI and ROVER fuel elements; this work either predates or later coincides with AEC work on the reprocessing of HTGR fuels. An extensive bibliography of domestic and foreign technical reports covering both the KIWI/ROVER fuel recovery technologies and related HTGR reprocessing technologies can be found in Appendix A of Ref. C1.

\section{C.2 OECD DRAGON PROJECT}

The Dragon Project Reports have been collected and recorded as Portable Data Files (PDFs) on a compact disk (CD) available from the OECD Nuclear Energy Agency (NEA) [C2]. The overall history of the Dragon Project can be found on the NEA CD in a book [C3] and a final technical report [C4].

The Dragon Project experimental work began with planning in 1956 and was centered primarily on the Dragon Reactor Experiment (DRE), which operated at 20 MWth between 1965 and 1976, and its associated Dragon Fuel Development Laboratory, Dragon Fuel Element Fabrication Laboratory, and the hot cells at A.E.E. Winfrith. Additional work was also carried out at other European laboratories in support of the OECD.

Fuel for the DRE was based on removable fuel elements of graphite clad tubes with multiple concentric annular/tubular fuel elements or later with single-tube annular fuel compacts or with teledial-pelletized fuel compacts of coated particles in a graphitized carbon matrix. The later fuel element designs are illustrated in Fig. C.1. The fuel tubes were arranged vertically in stringers and 

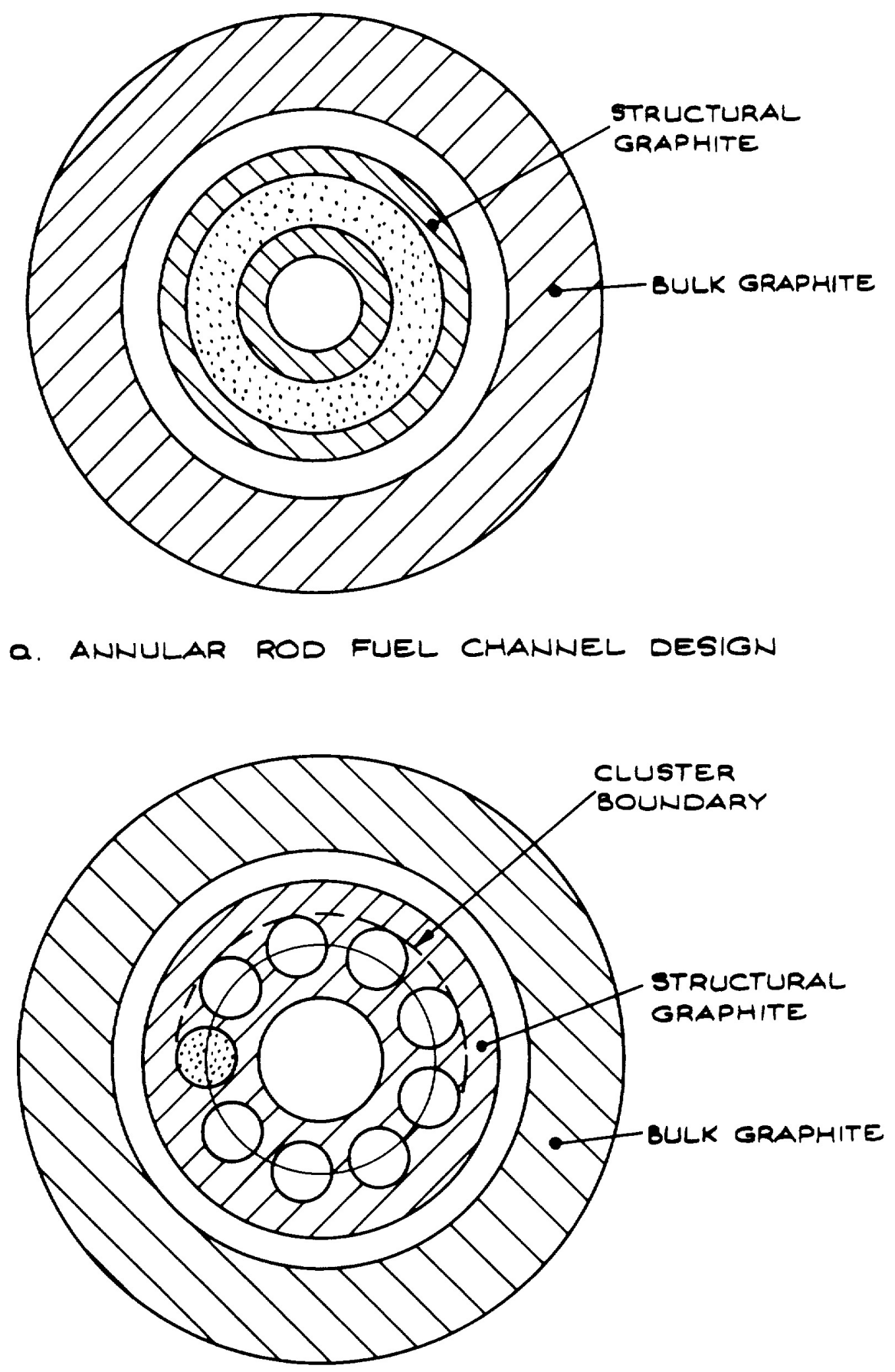

b. teleoial fuel channel debign

Fig. C.1. Later Dragon Reactor experiment (DRE) tubular fuel element designs-annular rods and teledial fuel.

inserted into semi-permanent graphite moderator structures arranged in a hexagonal pattern. The use of removable fuel elements separable from the rest of the core structure was pursued to facilitate the reduction of non-fuel structural volume and mass sent to reprocessing and/or spent fuel disposal. Other than the DRE, only the more recent Japanese High Temperature Test Reactor (HTTR) has used separable fuel element and in-core moderator structures. Today, it is generally recognized that 
reusable graphite structures in-core require a high-temperature, corrosion-resistant graphite with wellcontrolled shrinkage and swelling under neutron irradiation, that is, typically a graphite made with isotropic needle coke using isostatic molding during fabrication to limit the presence of cracks and voids.

The initial coated particle fuel used in DRE was high enriched uranium-thorium carbides $\left(\mathrm{HEUC}_{2}-\mathrm{ThC}_{2}\right)$ and was followed by high enriched uranium-thorium oxides $\left(\mathrm{HEUO}_{2}-\mathrm{ThO}_{2}\right)$ and later low enriched uranium oxide $\left(\mathrm{LEUO}_{2}\right)$. The fuel kernels were also studied with various oxygen and fission product gettering agents [C4]:

The main variants on the Reference $\mathrm{UO}_{2}$ fuel were to dilute with carbon (using the carbon agglomeration route or the WAR [Weak Acid Resin] process developed by Oak Ridge National Laboratory); to dilute with alumina $\left(\mathrm{UO}_{2} / \mathrm{Al}_{2} \mathrm{O}_{3}\right)$ or to alter the composition to uranium carbide with zirconium carbide additions. (UC/ZrC, $\mathrm{UC} / 5 \mathrm{ZrC})$. Some experiments also involved uranium carbo-nitride kernels."

For thorium oxide fertile particles, other gettering agents were also evaluated [C4]:

A large number of oxide getters was examined to explore the possibility of fission product gettering in thorium oxide fuels. $\left(\mathrm{Al}_{2} \mathrm{O}_{3}, \mathrm{Ce}_{2} \mathrm{O}_{3}, \mathrm{SiO}_{2}, \mathrm{ZrO}_{2}, \mathrm{Al}_{2} \mathrm{O}_{3} \cdot \mathrm{SiO}_{2}\right.$, $\mathrm{Cr}_{2} \mathrm{O}_{3}, \mathrm{Fe}_{2} \mathrm{O}_{3}, \mathrm{MoO}_{3}, \mathrm{MnO}_{2}, \mathrm{Nb}_{2} \mathrm{O}_{5}, \mathrm{TiO}_{2}, \mathrm{~V}_{2} \mathrm{O}_{5}, \mathrm{Y}_{2} \mathrm{O}_{3}$.).

In addition to kernel getters, the study of candidate coated particle fuels included BISO, TRISO, and multiple pyrocarbon $(\mathrm{PyC})$ and silicon carbide $(\mathrm{SiC})$ coating layers to demonstrate and evaluate fission product retention during irradiation and under accident conditions.

In addition, various compositions of plutonium-bearing fuel particles were fabricated and tested in irradiations and post-irradiation examinations including $\left(\mathrm{Th}_{0.84}-\mathrm{Pu}_{0.16}\right) \mathrm{C}_{2.4}$ and $\left(\mathrm{Th}_{0.95}-\mathrm{Pu}_{0.05}\right) \mathrm{C}_{2.35}$, $\mathrm{PuO}_{2} / \mathrm{Pu}_{2} \mathrm{O}_{3}$, and plutonium oxide diluted with carbon (Pu:C ratios of 1:30.5 and 1:21) [C5-C13].

The Dragon Project initially assumed that, for deployment of large HTGRs, the use of thorium in HEU/Th fuels to produce ${ }^{233} \mathrm{U}$ would require time to generate sufficient quantities of ${ }^{233} \mathrm{U}$ to replace

${ }^{235} \mathrm{U}$ in $\mathrm{HEU} / \mathrm{Th}$ fuel so that it would be necessary to use $\mathrm{Pu} / \mathrm{Th}$ fuels in the interim where supplies of fissile plutonium would be obtained from the reprocessing of other commercial reactor LEU-based spent fuels. Subsequently, large HTGR deployment studies were also conducted by the Dragon Project for once-through LEU fuel cycles.

Reprocessing and refabrication were addressed in the Dragon Project solely for HEU/Th fuels and focused primarily on a series of conceptual design studies and cost analyses, now much out of date, for a reprocessing/refabrication plant [C14-C18]. Only limited laboratory-scale testing of the head-end portion of reprocessing techniques was performed for (1) the electrolytic removal of carbon and (2) the grinding and leaching of the residual fuel material in nitric acid both with and without subsequent oxidation by adding a nitric acid-permanganate solution [C16.d]. Although there were no studies of the off-gas treatment or that for other waste streams for the conceptual design of the reprocessing/refabrication plant, there were studies of both noble gas trapping from releases during reactor operation [C19] and of spent fuel disposal options and associated costs, now out of date, including temporary storage, volume reduction by removing carbon and graphite cladding sleeves, and long-term storage of canned spent fuel particles [C20]. Reference C20 also discusses options for either storing or burning and off-gas scrubbing of the excess graphite and/or carbon sludge produced if the graphite is separated by electrolytic dissolution. No recommendations are made as to geologic disposal of canned residual spent fuel but as an addendum it was noted that such canned spent fuel material could be used to provide a radiation barrier in the storage facilities for fresh fuel containing HEU, ${ }^{233} \mathrm{U}$, or Pu.

Finally, only one report appears on the NEA CD of Dragon Project reports related to safeguards [C21]. This report extends the experience in using gamma-scanning for post-irradiation examinations to address the quantification of burn-up and the potential verification of reactor operating conditions 
during fuel irradiation where the latter can be deduced from the ratios of gamma-emitting fission products in spent fuel given the development of correlations between directly measurable fission product activities and useful information like spent fuel cooling time, burn-up, flux and initial fuel enrichment. Reference C21 also notes that "The primary source of error in gamma-spectrometric measurements on irradiated fuel elements is the necessary correction for gamma-self-absorption effects for an unknown fission product distribution." However, since the Dragon-type fuel element is in stringers and is separable from the graphite-moderator-core structure, the error is judged by the Dragon Project analysts to be negligible also given the low density $\left(\sim 1 \mathrm{~g} / \mathrm{cm}^{3}\right)$ and homogeneous distribution of the heavy-metal fuel material in the fuel element. The basic argument is that the Dragon-type separable fuel element is more easily quantifiable as to burn-up and operating conditions by gamma-spectrometric measurements.

The Dragon Reports also include various reactor physics fuel-cycle analyses for the different fuel types in the large Dragon-type HTGR for HEU/Th, Pu/Th and LEU fuels. These various reports can all be found on the NEA CD [C2].

\section{C.3 ARBEITSGEMEINSCHAFT VERSUCHS-REAKTOR (AVR)}

The AVR archival documentation has been collected and recorded as PDFs on a CD available from the OECD NEA [C22]. The CD contains both archival documents from AVR (almost exclusively in German) and a bibliography of papers and other documents, some of which can be found in journals or other sources such as conference proceedings as identified in the bibliography. While there are many documents on the fabrication and irradiation performance of both HEU/Th and LEU fueled pebbles, neither the archive nor the reference list in the bibliography appears to contain information related to AVR fuel reprocessing or disposal.

Papers on the AVR fuel reprocessing or disposal do appear elsewhere in two categories of collections: (1) papers appearing in conferences and journals and (2) reports, as cited in Appendix A to Ref. C.1, that were provided to AEC and later DOE contractors under the United States-Federal Republic of Germany High Temperature Reactor Research Exchange Program. This latter set of reports includes the GERHTR-series and certain JÜL-series reports.

Addressing the first category of papers first, there is one paper from 1969 [C23] discussing preliminary experiments for reprocessing AVR thorium-bearing fuel and there are three papers from the 1983 International Atomic Energy Agency (IAEA) Specialists Meeting in Moscow that do address AVR spent fuel head-end processing [C24.a], chemical processing [C24.b], and interim and long term storage [C24.c].

These papers from 1983 address the spent fuel handling issues for both the AVR HEU/Th and LEU spent fuel and that from the anticipated operation of the then (1983) new Thorium HighTemperature Reactor (THTR) in Germany, which was shutdown in 1989 after start-up in 1983. The head-end processing of spent pebble fuel [C24.a] involves the removal of graphitized carbon from the pebbles to reduce the volume to be reprocessed, and the conclusion reached in developing a flow sheet is quoted as follows:

Besides burning techniques different kinds of processes like mechanical, chemical or electrolytical disintegration, chlorination, etc. have been investigated. However, burning off the graphite proved to be the technically most feasible process and the reference reprocessing flowsheet evolving was therefore based on this head-end treatment method.

The chemical processing [C24.b] of the residual fuel kernels after grinding was based on the PUREX and THOREX processes to separate uranium (either residual HEU or depleted LEU), plutonium and residual thorium. 
In the first category of papers, spent fuel disposal [C24.c] was addressed at all stages from temporary storage in water-pool-immersed 50-pebble steel cans to longer term dry storage in 1000pebble steel cans to ultimate disposal of the 1000-pebble steel cans in either a borehole or salt dome, but as of 1983 no field testing had been performed on disposal options. Since 1983, the suitability for direct disposal of pebble fuel forms has been studied in more detail [C25, C26]. For pebble-bed fuel, especially LEU, direct disposal of pebbles packed in steel drums that are embedded in an underground salt dome was selected in the later German studies as the most economical means for disposal although the studies concluded "that other technical solutions for disposal besides embedding in salt rock seem possible and could easily be developed for countries with a different infrastructure and lacking suitable underground salt strata" [C26]. However, as of 1997, the issue was still being studied in Germany with spent pebble fuel in interim storage, and no final decision was made among options such as salt dome, borehole and co-disposal in steel canisters with LWR fuel [C27]; this situation has apparently not progressed to date.

The published German studies in this first category of papers did not address IAEA safeguards. The most recent studies of pebble bed spent fuel conducted by Idaho National Laboratory in the U.S. have concluded that:, even for deep-burn options, the spent pebble bed fuel would still be subject to IAEA safeguards the same as LWR spent fuel [C28]

The principal conclusion of this study is that the fully burnt spent fuel from the PBMR-400 reactor does not meet the IAEA criteria for termination of safeguards on measured discards. Therefore safeguards should be maintained on such spent fuel until it has been treated to meet said IAEA criteria. For completeness, it is important to note that spent fuel from prismatic block HTRs [or from LWRs] would have to be subjected to at least the same restrictions.

As noted above, additional references to reports from German studies of HTR fuel reprocessing by KFA-Jülich (GERHTR-series, JÜL-series, and Jül-Spez-series reports) can be found cited in Appendix A to Ref. C1. Hard copies of these reports are available at the DOE Office of Scientific and Technical Information (.DOE/OSTI) in Oak Ridge. Some of these are also available on microfiche in DOE and DOE contractor libraries. Reports covering the following subjects have been pulled aside at DOE/OSTI and have been requested to be scanned and uploaded onto the Energy Citations Database (http://www.osti.gov/energycitations/advancedsearch.jsp). Some of these reports are also listed on the IAEA's International Nuclear Information System (INIS at http://inisdb2.iaea.org/) but are not retrievable from that web site.

- Progress and related summary reporting on reprocessing thorium-bearing HTR fuels [C30C39]

- Head-end processing of HTR fuels [C40-C46]

- Dissolution processing of HTR fuels following head-end processing [C47-C54]

- Solidification of liquid wastes from HTR fuel reprocessing [C55, C56]

- Handling gaseous wastes from HTR fuel reprocessing [C57-C68]

- Handling solid wastes from HTR fuel reprocessing [C69]

- HTR spent fuel storage/disposal [C70]

- Fabricating ${ }^{232} \mathrm{U} /{ }^{228} \mathrm{Th}$-contaiminated ${ }^{233} \mathrm{U} / \mathrm{Th}$ kernels from reprocessed HEU/Th HTR fuel [71]

- HTR fuel reprocessing plant siting [C72, C73]

- Nuclear material accountability and safeguards [C74-C79] 


\section{C.4 UNITED STATES PROGRAMS ON HTGR FUEL REPROCESSING}

\section{C.4.1 Work from the 1940s}

In October 1944, Dr. Farrington Daniels of the University of Chicago Metallurgical Laboratory proposed to the AEC the consideration of the possibility of developing a high-temperature pebble bed reactor with uranium carbide fuel encased in graphite spheres cooled either by a gas or by molten bismuth [C80]. Subsequently, the AEC funded the Clinton Laboratories in Oak Ridge to conduct a technical review of the design and development issues for a high-temperature gas-cooled power pile [C81]. The technical review addressed alternatives to using graphite as the moderator including both beryllium $(\mathrm{Be})$ and beryllium oxide ( $\mathrm{BeO}$, beryllia). A major finding from the technical review with respect to reprocessing is found in Sect. 7.b (page 112) of Ref. C81 and is quoted as follows:

Since graphite fuel units may be used, considerable study was given to chemical reprocessing of graphite units. The use of graphite units will effect considerable saving in reprocessing costs. This saving is particularly significant because one of the major economic factors involved will be the cost of constructing and operating the chemical process plant...The advantage of the graphite units lies in the fact that it would be possible to recover the uranium, and to prepare a feed to the solvent extraction columns which is perhaps 100 times as concentrated as is possible in the case of $\mathrm{Be}-\mathrm{U}$ and $\mathrm{BeO}-\mathrm{UO}_{2}$ fuel."

The "considerable study" of the "chemical reprocessing of graphite units" referred to in Ref. C81 is documented in Ref. C82. This study involved reviewing the AEC-funded technical work and developments by the Y-12 Plant [C83], the University of California, and the Purdue University [C84] to address the salvage recovery of uranium from tramp uranium contamination of graphite and carbon tools and equipment used in processing and handling natural and enriched uranium and uranium enrichment tails. The principal technical method used to recover uranium that had become impregnated in graphite or carbon parts and tools was to grind off the surface of the graphite or carbon piece, burn the grindings, and leach the ashes with nitric acid. The use of burn-leach and grind-leach techniques in later HTGR fuel reprocessing research and development can be traced to the findings reported in Ref. C82. Subsequent to the issuance of Ref. C82, additional study was proposed to address remote processing of irradiated uranium-thorium fuels to facilitate the rapid recovery of fissile materials [C85]. In carrying out the additional study, the researchers in Oak Ridge found in 1948 the utility of recovering uranium from graphite by electrolytic disintegration/dissolution in nitric acid [C86, C87]. No further work was apparently conducted after 1948 on graphite fuel reprocessing at ORNL until the latter part of the 1950s, or at least such work if conducted is not documented in readily available papers and reports. Refs. C82 and C87 are the reports cited by ORNL documents issued after work on graphite fuel reprocessing was restarted in the late 1950s for both ROVER HEU recovery and HTGR spent fuel reprocessing.

\section{C.4.2 Unirradiated and Irradiated HEU Recovery from ROVER Fuels}

As indicated in Sect. C.1, the ROVER space rocket reactor program started at LANL in 1952. The ROVER HEU fuels recovery activities had four parts:

- Research and development at ORNL from 1957 to 1965 [C87-C99]

- Testing and reprocessing component development at the ICPP from 1965 to 1978 [C100-C109]

- Issuance of the Environmental Statement for ROVER reprocessing at the ICPP in 1972 [C110] 
- Execution of the ROVER fuels reprocessing at the ICPP, cold testing on unirradiated fuels in 1981 and hot work on irradiated fuels in 1983-1984 [C111]

In addition to the references cited above, there are annual and later quarterly progress reports issued by the ICPP from 1971 to 1978 that document the results of equipment design and testing for reprocessing graphite-based fuels including both ROVER and HTGR fuels [C112-C123].

The research and development work at ORNL addressed grind-leach and burn-leach followed by either chlorination, dissolution in a mixture of nitric and hydrofluoric acids, or fluorination for recovery of the uranium in a soluble form. Electrolytic disintegration/dissolution did not work satisfactorily because of the niobium carbide coatings on the coolant channels. As described in Ref. C111: "The dissolution process for this [ROVER] graphite-matrixed fuel used two hot fluidized beds of alumina particles to convert the fuel elements into gaseous combustion products and a uranium and niobium bearing ash. Ash was collected, weighed, and then sent to a specialized plastic dissolver, where it was dissolved in a mix of hydrofluoric acid and nitric acid." This process is essentially the process recommended by ORNL from final research and development testing reported in Ref. C99.

\section{C.4.3 Background and Context for the GCR and Thorium Utilization Programs}

Much of the history of ORNL work on the GCR and Thorium Utilization Programs can be found summarized in ORNL divisions' 50-year histories for the Engineering Technology Division (formerly the Technical Division) [C124], the Chemical Technology Division (formerly also part of the Technical Division) [C125], and the Metal \& Ceramics Division (formerly the Metallurgy Division) [C126]. As discussed in Ref. C124, the AEC initiated the GCR Program in 1957 at the direction of Congress due to Congressional concerns about staying abreast of the perceived success of the British $\mathrm{CO}_{2}$-cooled Magnox and Advanced Gas-cooled Reactor Programs. The initial effort at ORNL was to develop a graphite-moderated, helium-cooled, steel-clad, enriched uranium, but higher temperature equivalent to the British GCRs. This initial effort at ORNL included collaborations with the Tennessee Valley Authority and another AEC contractor, Kaiser Engineering, to design and build the Experimental Gas-Cooled Reactor (EGCR) that was completed but never operated at the ORNL site. Also, in 1957, the AEC had contracted with GA to design the Peach Bottom HTGR and with an architect-engineering firm, Sanderson and Porter in New York, to develop the conceptual design of a pebble bed reactor. In 1958-1959, in collaboration with the Battelle Memorial Institute also under AEC contract, ORNL began work on the pebble bed reactor concept based on using doubly-PyCcoated (BISO) fuel particles of carbide fuel in graphite pebbles. By 1964, the EGCR and the pebble bed design effort had been canceled by the AEC to pursue only the design and construction of the Peach Bottom HTGR. However, ORNL was chartered to work with GA on HTGR fuel and materials development and to collaborate with work at KFA-Jülich on fuel and materials for the AVR.

As discussed in Ref. C125, the Laboratory Section of the former ORNL Technical Division, which section later became the Chemical Technology Division, developed the THOREX Process to separate ${ }^{233} \mathrm{~Pa},{ }^{233} \mathrm{U}$, and thorium in 1952 using the war-time-built concrete hot cells in Building 205, later designated as Building 3019, to reprocess targets irradiated in the X-10 Graphite Reactor at ORNL [C127, C128], where the table in Ref. C128 provides an historical summary of the dates of work in Building 3019 including the preparation of ${ }^{233} \mathrm{U}$ for various experiments and of plutonium sol-gel particles for Fuel Test Element-13 irradiated in Peach Bottom Unit 1 HTGR. As also discussed in Ref. C125, the AEC initiated the Thorium Utilization Program in 1961 with the objective of developing a thorium-based breeder reactor for breeding ${ }^{233} \mathrm{U}$; hence, the subsequent ORNL research and development efforts were pursued on the Molten Salt Reactor technology development and technical support to the Bettis Atomic Power Laboratory work on the Light Water Breeder Reactor (LWBR) Program [C125]. However, the HTGR as a converter reactor on the HEU/Th cycle was pursued in concert with the Thorium Utilization Program, and in 1970 the Thorium Utilization 
Program merged with the GCR Program as the HTGR fuel recycle subprogram, which continued until 1978 [C125, C126]. As in the Dragon Project, besides HEU/Th fuel development, the AEC and later DOE GCR Program work at ORNL and GA also addressed plutonium and plutonium-thorium fuels development and later LEU fuel for HTGRs.

\section{C.4.4 GCR Fuels Reprocessing Work from 1957 to 1970}

Conducted at ORNL in parallel to the ROVER HEU recovery work and prior to the consolidation of the GCR and Thorium Utilization Program in 1970, the ORNL work on HTGR fuels reprocessing concentrated initially on the fuels used in the first core of Peach Bottom Unit 1 and the AVR, namely, HEU/Th carbide BISO-coated particles [C129-C146]. One key finding from this period is that ball milling was not very effective in replacing grind-leach or burn-leach options for removing external carbon from the coated particles and would not fully-crush the hard fuel kennels to facilitate leaching [C146]. In 1960-1961, the AEC also contracted with Aeroprojects Incorporated to supplement work being performed at ORNL on the grind-leach process to see if the application of ultrasonic energy could be used to accelerate the extraction, diffusion and dissolution of uranium recovery from grindleach [C147]. While the results of preliminary testing of ultrasonic assisted leaching on unirradiated materials proved to be encouraging, development of this technology was apparently not pursued further with a preference shown for pursuing burn-leach instead. In 1966-1967, work also started on the reprocessing of urania-thoria (oxide) kernels [C148]. In 1967-1968, work was initiated on developing reprocessing techniques for the SiC-coated TRISO carbide particles [C149-C151] to be used in Fort St. Vrain and other future-planned HTGRs at the time.

In 1964, GA also began to work on reprocessing of HTGR fuels. This early GA work up to 1970 included:

- Joint studies with Nuclear Fuel Services at the West Valley reprocessing pilot plant in New York on integrating HTGR fuels head-end processing with light water reactor fuel reprocessing facility [C152, C153].

- Design and cost considerations for HTGR centralized fuel reprocessing plants [C154, C155].

- Reprocessing of SiC-coated TRISO particle fuel [C156, C157] and assessing the impact of fuel design changes on reprocessing costs [C158].

- Cold-testing development of head-end processing using small experimental batches of fuel [C159, C160].

- Interim storage of HTGR spent fuel prior to reprocessing [C161].

\section{C.4.5 ORNL Experience with the Fabrication of ${ }^{233}$ U-bearing Fuel}

One of the key aspects of recycling and refabrication of ${ }^{233} \mathrm{U}$ from HEU/Th reprocessing is the fact that recovered ${ }^{233} \mathrm{U}$ contains ${ }^{232} \mathrm{U}$ that has decay daughter products that are strong gamma emitters thus making the ${ }^{233} \mathrm{U}$ radioactive in proportion to the content of ${ }^{232} \mathrm{U}$. The ${ }^{232} \mathrm{U}$ content of the ${ }^{233} \mathrm{U}$ used in ORNL fabrications of fuel varied from 6 parts per million (ppm) to $68 \mathrm{ppm}$ while the ${ }^{232} \mathrm{U}$ content in ${ }^{233} \mathrm{U}$ recovered from the thorium in highly-irradiated HTGR fuels would be several hundred ppm making the recovered ${ }^{233} \mathrm{U}$ too radioactive for any post-processing or refabrication into fresh fuel except by remote handling [C162].

As noted above, the ${ }^{233} \mathrm{U}$-bearing fuel fabricated at ORNL was fabricated in the walk-in hot cells in Building 3019 [C126, C128]. ORNL fabricated several batches of ${ }^{233} \mathrm{U} /$ thorium oxide-bearing fuel for either critical experiments or chemical testing in different types of reactor lattices [C163-C166], but there is no record of any irradiation experiments using this material except for the LWBR where the fuel was fabricated as U/Th LWR-type pellets at Bettis using ${ }^{233} \mathrm{U}$ with low ppm values for ${ }^{232} \mathrm{U}$ and that had been chemically cleaned at ORNL of ${ }^{232} \mathrm{U}$ decay daughter products using a process developed at ORNL [C167]. For particle fuels other than those used for making vibratory-compacted 
fuel rods, ORNL fabricated both ${ }^{233} \mathrm{UO}_{2}-\mathrm{ZrO}_{2}$ kernels and $300 \mu \mathrm{m}$ diameter ${ }^{233} \mathrm{UO}_{2}-\mathrm{ThO}_{2}$ kernels with a Th/U mole ratio of $3 / 1$ and ${ }^{232} \mathrm{U}$ content of $<6 \mathrm{ppm}$ [C168] for use in reactor physics experiments at Battelle Northwest Laboratories (BNWL). Prior to shipment to BNWL, the ${ }^{233} \mathrm{UO}_{2}-\mathrm{ThO}_{2}$ kernels were coated with $100 \mu \mathrm{m}$ thick layer of PyC in a 5-in. coater located in a shielded glove box in Building 4508 at ORNL [C169]. These particles were the only coated particle fuel made with ${ }^{233} \mathrm{U}$. All subsequent ORNL experimental development of kernel and coated particle fabrication, irradiation and post-irradiation examinations for U/Th recycle fuel used HEU/Th [C170-C174] starting in the 1960s with testing of $\mathrm{UO}_{2}$ and $\mathrm{Th}_{0.8} \mathrm{U}_{.0 .2} \mathrm{O}_{2}$ and developing into the new reference fuel kernel, as of 1976, being the weak-acid-resin-derived (WAR) $\mathrm{UO}_{2}-\mathrm{UC}_{2}$, which is the basis for the current uranium oxicarbide (UCO) standard for the current U.S. LEU HTGR fuel.

\section{C.4.6 Thorium Utilization Program—GCR Fuel Reprocessing/Refabrication}

In 1968, the AEC chartered the ICPP to develop conceptual design criteria for a small reprocessing plant (260 MT per year) to handle the reprocessing of AEC-owned HTGR spent fuels irradiated in AEC-chartered demonstration reactors such as Peach Bottom Unit 1 and Fort St. Vrain. [C175]; at that time, the AEC plans for next steps of this program were the development of the conceptual design by an architect-engineer and the establishment of a cost estimate for the facility and its operations. In 1969, the AEC chartered a Task Force on Advanced Converter Reactors to provide direction on future research, development and deployments of advanced concepts including the HTGR [C176]; reprocessing and thorium utilization were addressed in the task force efforts to define future work for the AEC. The ORNL efforts on thorium utilization outside the work performed in Building 3019 at ORNL focused on refinement of the THOREX process at a pilot scale in the Thorium-Uranium Recycle Facility (TURF) [C177] in Building 7930 at ORNL. The design description for TURF, which was only partially completed, is given in Ref. C153. After the GCR and Thorium Utilization Programs were merged in 1970, a National HTGR Fuel Recycle Development Program Plan ${ }^{*}$ [C178] was written by ORNL and GA that called for the design and construction of an HTGR Fuel Refabrication Pilot Plant. ORNL proposed that this pilot plant be located adjacent to TURF at ORNL as the site of a proposed HTGR Fuel Reprocessing Facility (HTGR-FRF). An AEC-mandated preferred alternative to locating the HTGR-FRF at TURF was to place the facility adjacent to the ICPP at the National Reactor Test Station (NTRS) in Idaho [C179]. While the conceptual design documentation of the ORNL-proposed HTGR Fuel Refabrication Pilot Plant can not currently be located as a final report, ${ }^{\dagger}$ certain common design features are briefly described in the Final Environmental Statements for the proposed ORNL and ICPP facilities [C180, C181]. Only two ORNL internal reports were found in ORNL Laboratory Records Central Files on design aspects of the HTGR Fuel Refabrication Pilot Plant [C182, C183]. As for the HTGR-FRF to have been located adjacent to the ICPP in Idaho, Ref. C116 indicates that by 1975 the U.S. Energy Research and Development Administration (ERDA) had halted the development and design of the HTGR-FRF but that a four-volume conceptual design report had been completed by the Ralph M. Parsons Company (RMP) architect-engineering firm. Ref. C116 states that the HTGR-FRF conceptual design report includes (a) conceptual design engineering documents supporting the cost estimate, (b) a conceptual cost estimate, (c) special engineering studies covering 13 design-related subjects, and (d) detailed schedules for accomplishing the Title I, Title II, construction, and procurement activities. In addition,

\footnotetext{
*The Plan was reportedly revised three times based on references to later revisions in later ORNL, GA and ICPP reports; however, only a pen-and-ink mark-up of Revision 1 has been found in the ORNL Central Files in Laboratory Records and nothing at DOE/OSTI.

${ }^{\dagger}$ ORNL report, HTGR Fuel Refabrication Pilot Plant_Conceptual Design Report, GCR: 74-30, Volumes 1 through 4 (Nov. 1, 1974). This report could not be located in ORNL Laboratory Records; however, sections of the report (that is, individual system design descriptions) were found in ORNL program files for the HTGR Fuel Recycle Program, Box IDs 199601868 (Location OSTI/03301) and 199601863 (Location OSTI/03296). No attempt was made to reconstitute the report from the individual sections found nor to move the documents into ORNL Laboratory Records Central Files.
} 
two consulting organizations, MB Associates and Programmed and Remote Systems Corporation, are reported in Ref. C116 to have summarized studies of proposed remote handling features for the HTGR fuel reprocessing demonstration facilities. The conceptual design report for the HTGR-FRF was not published as a public document, but at least portions of the conceptual design documentation exist in the High Level Waste archive files at INL in document retrieval numbers HLW-REF-6512 through HLW-REF-6515, HLW-REF-6548 through HLW-REF-6551, and HLW-REF-6558. Whether all the design documentation, associated studies, and cost estimates are in the INL High Level Waste archives is not known.

Although construction of the HTGR Fuel Refabrication Pilot Plant was not pursued at ORNL nor was the completion pursued for the HTGR-FRF at Idaho, GA did set up a cold line for testing reprocessing equipment, and the ICPP executed a similar testing program for equipment. There are numerous reports from ORNL, GA, and the ICPP that address various aspects, components and features that would have been included or addressed in constructing and operating the Pilot Plant and the Reprocessing Facility to handle HTGR fuel:

- General equipment considerations in planning [C151, C162, C184, C185]

- Head-end processing (carbon burning) and reprocessing off-gas treatment by Krypton Absorption in Liquid $\mathrm{CO}_{2}$ (KALC) to remove krypton, radon, and ${ }^{14} \mathrm{C}$ [C162, C186-C234]

- Pneumatic handling and classification of irradiated, separated fuel particles [C197, C228, C235-C237]

- Dissolution studies by GA [C238-C242]

- Remote fabrication and inspection of fuel kernels, coated particles and rods and scrap recovery-recycle [C242-C252]

- Production/quality control in HTGR fuel refabrication [C253]

- Waste management for liquid and solid wastes and update of off-gas treatment [C254-C256]

- Economic analyses [C257-C260]

- Nuclear material accountability and safeguards [C250, C261-C263]

- Criticality safety considerations [C264]

- Enhancing proliferation deterrence by fission product spiking of recycle fuel [C265-C267]

- Open research and development requirements [C268]

- Progress between 1971 and 1978 at ICPP in various equipment testing for both ROVER HEU recovery and HTGR coated particle fuel reprocessing [C112-C123]

\section{C.4.7 Other Work by GA}

During the 1970s in addition to the GA reports cited above, GA reported its progress in developing HTGR fuel reprocessing methods in a cold test facility in a series of quarterly progress reports on the Thorium Utilization Program later renamed the HTGR Fuel Recycle Program and then the Consolidated Reprocessing Program. References C269 through C287 cite this series of reports. The continuing reports in this series issued after May 1979 until 1984 were initially designated to be APPLIED TECHNOLOGY: DOE/OSTI is now concerned that, prior to public release, these limited distribution reports need to be reviewed for Export Controlled Information (ECI); however, these limited reports in the GA-C16172/-series are available to DOE and DOE contractor staff who are registered users (with approved access) of the DOE/OSTI Science Research Connection (SRC at https://www.osti.gov/src/logon.jsp ).

GA has also issued a number of reports, not cited above, on various relevant topics to spent fuel reprocessing:

- $\quad$ Spent fuel shipping, storage, reprocessing and refabrication technologies [C288-C290]

- Studies of reprocessing LEU/Th fuels [C291, C292]

- HTGR spent reflector block disposal study [C293] 
- Cold test reprocessing of unirradiated German $\mathrm{HEU}^{-} \mathrm{ThO}_{2}$ pebbles [C294, C295]

- Reports on the HTGR Spent Fuel Treatment Program from the early 1980s addressing the LEU fuel cycle and delays in reprocessing [C296, C297]

\section{C.4.8 GCR Program-Plutonium Fuel}

Reference C268 addresses the open research and development requirements for recycle of both

${ }^{233} \mathrm{U}$ and plutonium fuels in 1979 after the recycle program had ended; however, ORNL and GA had jointly worked on the potential recycle of plutonium from LWRs in HTGR fuels for over a decade prior to 1979 [C298]. The major thrust of the preceding work had been the fabrication, irradiation, and post-irradiation examination of Fuel Test Element-13 (FTE-13) in the Peach Bottom HTGR [C299-C303]; unfortunately, the detailed post-irradiation examination reports by both ORNL [C301] and GA have never been published in the open literature. It is judged to be more than a bit unusual that the substantive technical reports underlying the marketing for the on-going GT-MHR work under the Russian program for Fissile Materials Disposition and the Deep-Burn Program have not been issued as publicly available and reviewed reports.

\section{C.4.9 Spent Fuel Disposal}

The storage and ultimate disposal of German pebble bed spent fuel in salt mines are addressed in refs. C24.c through C27. Other references for spent fuel disposal, as it relates to volume reduction as also required for reprocessing, are discussed briefly in Sect. 2 and in Refs. 47-56 in the main body of the report.

\section{C.5 RECENT DEVELOPMENTS}

In 1977, a researcher at the Japan Atomic Energy Research Institute (JAERI) proposed the use of fluorination to remove the $\mathrm{SiC}$ coatings of HTGR fuels [C304]. While both chlorination and fluorination had been studied previously at ORNL [C93-C96, C136-C138] and KFA-Jülich [C29-C33, C42, C57], these previous studies had focused either on uncoated carbide fuels encased in graphite or pre-ground fuel particles with the coatings no longer intact. The JAERI proposal was the first to address $\mathrm{SiC}$ coating removal using the highly-chemically-reactive and corrosive properties of a halogen gas.

In the last few years, renewed interest in HTR fuel reprocessing has led to two patents on headend processing by the European Union [C305, C306]. Ref. C306 is actually another version of that in Ref. C305 proposed to be applied to the recovery of radio-nuclides in contaminated graphite parts from facility decommissioning. Both patented techniques rely upon electrolytic disintegration/ dissolution that was initially studied and tested by ORNL in 1948 [C86, C87] and later in the early 1960s [C92, C133], which later testing gave disappointing results both in separating uranium in the presence of niobium carbide coatings for ROVER fuel elements and in separating uranium and thorium in BISO-coated HTGR fuels. Therefore, electrolytic disintegration/dissolution was not pursued further in the United States due to the concentration of development effort on grind-leach and burn-leach by ORNL, GA and ICPP focusing on the reprocessing of HEU/Th fuels. The Dragon Project [C16.d] also only applied electrolytic disintegration to remove graphite cladding leaving coated particles and graphite fines to be separated by grind-leach to recover uranium and thorium. However, Ref. C305 is developed to apply to the disintegration/dissolution of both encasing graphite and the encased coated particles using energetic electric pulses applied to LEU fuel. So far it appears that no one has yet suggested the possibility of including or adding ultrasonic-assisted disintegration/ dissolution that was tested by Aeroproducts Incorporated in 1960-1961 for ultrasonic-assisted grindleach [C147] but also never further pursued to replace grind-leach/burn-leach as the preferred techniques developed in the United States. 


\section{C.6 CONCLUSIONS}

As demonstrated by the information provided in this appendix, extensive development and testing have been performed for the reprocessing of graphite-encased coated particle fuels; however, none of the techniques studied have been brought to the level of commercial deployment nor progressed beyond laboratory-scale demonstrations. Cost estimates for commercial applications are all dated. The United States design documentation and cost estimates for both reprocessing and refabrication pilot-scale facilities exist in pieces in archives and were based on reprocessing HEU/Th fuels and refabrication using ${ }^{233} \mathrm{U} / \mathrm{Th}$ not the $\mathrm{LEU} \rightarrow$ plutonium closed fuel cycle. Burn-leach reprocessing generates substantial quantities of radioactive gases including ${ }^{14} \mathrm{CO}_{2}$, and grind-leach and electrolytic disintegration/dissolution reprocessing each generate substantial amounts of liquid and sold wastes along with radioactive noble gases. Although the technical baselines have been established for various reprocessing options for graphite-encased coated particle fuels, the practicality and cost effectiveness are yet to be demonstrated.

\section{C.7 REFERENCES}

C1. T. Hertzler, Technical and Regulatory Review of the Rover Nuclear Fuel Process for Use on Fort St. Vrain Fuel, EGG-WTD-10550, Science Applications International Corporation, Idaho Falls, Idaho, February 1993, http://www.osti.gov/energycitations/servlets/purl/6420824-pMnptr/ and http://www.osti.gov/energycitations/servlets/purl/10150968-hdtVFe/.

C2. IRPhE-DRAGON-DPR, OECD High Temperature Reactor Dragon Project, Primary Documents, NEA-1726 IRPHE-DRAGON-DPR, on compact disk that may be ordered at http://www.nea.fr/abs/html/nea-1726.html.

C3. E.N. Shaw, History of the OECD Dragon Project-Europe's Nuclear Power Experiment, Pergamon Press, London, 1983 (NEA CD file name Dragon-his.pdf).

C4. F.P.O. Ashworth et al., A Summary \& Evaluation of the Achievements of the DRAGON Project $\&$ its Contribution to the Development of the High Temperature Reactor (HTR), Dragon Project report 1000, A.E.E. Winfrith, Dorchester, Dorset, England, November 1978 (NEA CD file name DPR1000.pdf).

C5. G. Vanhellemont, J. Beullens, and H. Bairiot, Exploratory Experiments on the Feasibility of Th and Pu Sol-gel Particles, Dragon Project Report 349, A.E.E. Winfrith, Dorchester, Dorset, England, May 1965

C6. B. Riley and J.H. Worth, The Fabrication and Irradiation Behaviour of Plutonium-Thorium Carbide Coated Fuels, Dragon Project Report 414, Metallurgy Division, Atomic Energy Research Establishment, Harwell, Berkshire, England, March 1966.

C7. J.T. Dalton, Constitutional Studies in the Th-Pu-C System, Dragon Project Report 415, February 1966.

C8. G.W. Horsley et al., The Manufacture of Plutonium Fuelled Fission Product Retaining Coated Particles for Irradiation in the Dragon Reactor Experiment, Dragon Project Report 525, A.E.E. Winfrith, Dorchester, Dorset, England, February 1967.

C9. P. Barr et al., High Temperature Irradiation Experiments on Plutonium Bearing Coated Particle Fuel, Dragon Project Report 526, Danish A.E.K. AB ATOMENERGI and A.E.E. Winfrith, Dorchester, Dorset, England, February 1967. 
C10. H. Bairiot, A. Klusmann, and M.S.T. Price, Plutonium Coated Particle Production for HTR Fuel Elements, Dragon Project Report 534, Belgo Nucléaire and A.E.E. Winfrith, Dorchester, Dorset, England, July 1967.

C11. Belgo Nucléaire Centre d'Étude de l'Énergie Nucléaire (CEN), Development of Plutonium Fuelled Coated Particles for Irradiation in the Dragon Reactor Experiment, Dragon Project Report 543, A.E.E. Winfrith, Dorchester, Dorset, England, May 1968.

C12. U. Hansen, Plutonium in High Temperature Reactors, Dragon Project Report 899 (Paper presented to the IAEA Panel on Plutonium Utilisation in Thermal Power Reactors at Karlsruhe 25-29 November 1974), A.E.E. Winfrith, Dorchester. Dorset, England, December 1974.

C13. G. Formann et al., The Irradiation Behaviour of Plutonium Coated Particle Fuel in the Dragon Reactor Experiment, Dragon Project Report 937, A.E.E. Winfrith, Dorchester, Dorset, England, June 1975.

C14. G.W. Horsley, L.A. Podo, and F.C. Wood, Studies on the Reprocessing and Refabrication of H.T.G.R. Fuels in the OECD Dragon Project, Dragon Project Report 338 (paper presented at the EURATOM Symposium on Fuel Cycles of High Temperature Reactors, Brussels, Belgium, 10-11 June 1965), A.E.E. Winfrith, Dorchester, Dorset, England. April 1965.

C15. Chemical Plant Design Office, Engineering Group, Risley, and Technical Branch, Production Group, Windscale, H.T.R. Reprocessing Study, Dragon Project Report 398, United Kingdom Atomic Energy Authority, Risley, Warrington, Lancashire, England, December 1965.

C16. F. Calori et al. (Comitato Nazionale per l'Energia Nucleare, Italy), An Experimental Investigation and Assessment of Reprocessing and Refabrication of High Temperature Reactor Fuel, Dragon Project Report 461, Parts 1 to 4, A.E.E. Winfrith, Dorchester, Dorset, England, February 1967.

a. Part 1-Technical and Economic Evaluation of recovering Thorium and Uranium in a Central Integrated Facility for Reprocessing and Refabrication

b. Part 2-Drawings

c. Part 3-Specifications

d. Part 4-Head-End Processing for U-Th Carbide Graphite Fuel

C17. G.D.C. Short and J. Wharton (U.K.A.E.A. Risley), Preliminary Summary of the Estimated Costs of Reprocessing and Refabrication of Fuels, Dragon Project Report 470, A.E.E. Winfrith, Dorchester, Dorset, England, February 1968.

C18. J. Wharton and G.D.C. Short, H.T.R. Fuel Reprocessing and Refabrication Study, Dragon Project Report 540, United Kingdom Atomic Energy Authority, Risley, Warrington, Lancashire, England, February 1968.

C19. J.C. Shorrock, H. Staub, and Ch. Burckhardt, Studies on the Delay and Trapping of Fission Product Noble Gases, Dragon Project Report 363, A.E.E. Winfrith, Dorchester, Dorset, England, July 1965.

C20. J. Wharton, A.P. Thornhill, and E.S. Chapman, HTR Fuel Disposal Study, Dragon Project Report 450, United Kingdom Atomic Energy Authority, Risley, Warrington, Lancashire, England, July 1966.

C21. H. Hick and J. York, Gamma-Spectrometric Safeguard Control of Gas Cooled High Temperature Reactors, Dragon Project Report 764, A.E.E. Winfrith, Dorchester, Dorset, England, August 1971. 
C22. IRPhE/AVR, High Temperature Reactor Experience, Archival Documentation, NEA-1739/02 IRPHE/AVR, on compact disk that may be ordered at http://www.nea.fr/abs/html/nea-1739.html.

C23. E. Fischer et al., "Development of Reprocessing Procedures for Thorium-containing Fuel Elements," pp. 201-223, Reprocessing of Highly-Irradiated Fuels, Report of a Panel of Experts Sponsored by the International Atomic Energy Agency and Held in Vienna, 27-30 May 1969, International Atomic Energy Agency Vienna, 1970, http://www.osti.gov/energycitations/servlets/purl/4696849-71oFyp/4696849.pdf.

C24. Specialists' Meeting on Gas-Cooled Reactor Fuel Development and Spent Fuel Treatment, Moscow, USSR, 18-21 October 1983, IWGGCR/8, Central Research Institute of Information and Technical-Economical Studies on Atomic Science and Technology, Moscow (1985), as uploaded to the Internet by the International Atomic Energy Agency, Vienna, at http://www.iaea.or.at/inisnkm/nkm/aws/htgr/fulltext/iwggcr8.pdf:

a. G. Kaiser et al., "Head-end processing of HTR fuel elements," pp. 357-368.

b. F. Zimmcr and E. Merz, "Chemical processing of HTR fuels applying either thorex or purex flow sheets," pp. 333-344.

c. G. Kaiser, U. Brinkmann, and R. Duwe, "Research, development and demonstration work on interim and final storage of HTR fuel elements," pp. 303-314.

C25. H.U. Brinkmann et al., "Contributions towards the Development of a Packaging Concept for the Final Disposal of Spent HTGR Pebble Fuel," Nuclear Engineering and Design 118, pp. 107-113 (1990), North-Holland Publishers.

C26. N. Kirch, H.U. Brinkmann, and P.H. Brücher, "Storage and Final Disposal of Spent HTR Fuel in the Federal republic of Germany," Nuclear Engineering and Design 121, pp. 241-248 (1990), North-Holland Publishers.

C27. D. Niephaus, S. Storch, and S. Halaszovich, "Experience with the interim storage of spent HTR fuel elements and a view to necessary measures for final disposal," Technologies for gas cooled reactor decommissioning, fuel storage and waste disposal, IAEA-TECDOC-1043, Technical committee meeting on technologies for gas cooled reactor decommissioning, fuel storage and waste disposal. Jülich (Germany) 8-10 September 1997, International Atomic Energy Agency, Vienna (Austria), http://www.iaea.org/inisnkm/nkm/aws/htgr/fulltext/29059911.pdf.

C28. A.M. Ougouag, H. D. Gougar, and T. A. Todd, Evaluation of the Strategic Value of Fully Burnt PBMR Spent Fuel, INL/EXT-06-11272, Idaho National Laboratory, Idaho Falls, ID, May 2006, http://www.inl.gov/technicalpublications/Documents/3372140.pdf.

C.29. Reprocessing of thorium-containing nuclear fuels, Report on activities in the First Six Months of 1969, GERHTR--39, Institut für Chemische Technologie, Kernforschungsanlage Jülich G.m.b.H., Jülich, Germany, June 1969, http://www.osti.gov/energycitations/servlets/purl/4558640-OwSIVh/4558640.pdf.

C30. Reprocessing of thorium-containing nuclear fuels, Report on activities in the Second Half Year 1969, GERHTR-41, Institut für Chemische Technologie, Kernforschungsanlage Jülich G.m.b.H., Jülich, Germany, December 1969, http://www.osti.gov/energycitations/servlets/purl/45586050216rw/4558605.pdf.

C31. Reprocessing of thorium-containing nuclear fuels, Report on activities in the First Half Year 1970, GERHTR-42, Institut für Chemische Technologie, Kernforschungsanlage Jülich G.m.b.H., Jülich, Germany, August 1970, http://www.osti.gov/energycitations/servlets/purl/4488895WUvd7R/4488895.pdf. 
C32. Reprocessing of thorium-containing nuclear fuels, Report on activities in the Second Half Year 1970, GERHTR-43, Institut für Chemische Technologie, Kernforschungsanlage Jülich G.m.b.H., Jülich, Germany, 1971, http://www.osti.gov/energycitations/servlets/purl/4610858KX3dko/4610858.pdf.

C33. Reprocessing of thorium-bearing nuclear fuels, Annual report July 1, 1971-June 30, 1972, GERHTR-58, Institut für Chemische Technologie, Kernforschungsanlage Jülich G.m.b.H., Jülich, Germany, August 1972, http://www.osti.gov/energycitations/servlets/purl/4290159NRcAO6/4290159.pdf.

C34. Reprocessing of thorium nuclear fuels, Annual activities report, July 1, 1972-June 30, 1973, GERHTR-97, Institut für Chemische Technologie, Kernforschungsanlage Jülich G.m.b.H., Jülich, Germany, August 1973.

C35. 1973 progress report of the Institute for Chemical Technology, GERHTR-106, Institut für Chemische Technologie, Kernforschungsanlage Jülich G.m.b.H., Jülich, Germany, 1973.

C36. Reprocessing of thorium nuclear fuels, Annual activities report, July 1, 1973-June 30, 1974, GERHTR-140, Institut für Chemische Technologie, Kernforschungsanlage Jülich G.m.b.H., Jülich, Germany, August 1973.

C37. Reprocessing of thorium nuclear fuels, Annual activities report, July 1, 1975-June 30, 1976, GERHTR-183, Institut für Chemische Technologie, Kernforschungsanlage Jülich G.m.b.H., Jülich, Germany, August 1976.

C38. Fachseminar zur Wiederaufarbeitung und Entsorgung im Thorium-Brennstoffkreislauf (Technical seminar on the reprocessing and waste disposal in the thorium-fuel cycle), Jül-Conf30 (in German), Kernforschungsanlage Jülich G.m.b.H., Jülich, Germany, February 1979.

C39. E. Merz, Wiederaufarbeitung im Thoriumbrennstoffkreislauf (Reprocessing of the thorium fuel cycle), Jül-Spez-239 (in German), Institut für Chemische Technologie, Kernforschungsanlage Jülich G.m.b.H., Jülich, Germany, January 1984.

C40. J. Krahe and F. Mueller, Thermochemistry of the systems $\mathrm{U}$, Th, $\mathrm{Pa}, \mathrm{C}, \mathrm{O}_{2}$, and $\mathrm{Cl}$, GERHTR-34 (JÜL-565-CT), Institut für Chemische Technologie, Kernforschungsanlage Jülich G.m.b.H., Jülich, Germany, 1968.

C41. M. Laser, H. Barnert-Wiemer, H. Beaujean, E. Merz, and E. Vygen, AKUT: a process for the separation of aerosols, krypton, and tritium from burner off-gas in HTR fuel reprocessing, GERHTR-109 (CONF-740807-19), Institut für Chemische Technologie, Kernforschungsanlage Jülich G.m.b.H., Jülich, Germany, 1973, http://www.osti.gov/energycitations/servlets/purl/4350170-venFy2/ and also at pages 246-262 of the $13^{\text {th }}$ AEC Air Cleaning Conference, Volume 1, http://www.osti.gov/energycitations/servlets/purl/4179572-1RHSRd/.

C42. J. Bohnenstingl, H. Gebhardt, M. Laser, and G. Lossmann, CHLORINEX: development of a method for the high-temperature chlorination of Th-containing fuel elements as head-end stage of the reprocessing, GERHTR-141 (JÜL-1129-CT), Institut für Chemische Technologie, Kernforschungsanlage Jülich G.m.b.H., Jülich, Germany, October 1974.

C43. R. Boehnert, G. Kaiser, H. Pirk, and U. Tillessen, HTR combustion head end comparison of the shaft furnace and fluidized bed processes, GERHTR-145 (translation of JÜL-1152), Institut für Chemische Technologie, Kernforschungsanlage Jülich G.m.b.H., Jülich, Germany, January 1975.

C44. H. Barnert-Wiemer and R. Boehnert, Costs of head-end incineration with respect to $\mathrm{Kr}$ separation in the reprocessing of HTR fuel elements, GERHTR-173 (translation of JÜL-1320), 
Institut für Chemische Technologie, Kernforschungsanlage Jülich G.m.b.H., Jülich, Germany, July 1976.

C45. R. Boehnert and C. Walter, VENUS: cold prototype installation of the head-end of the reprocessing of HTR fuel elements, Activity report, 1 July 1976-31 December 1976, GERHTR182 (translation of KFA-ICT-IB-411/77), Institut für Chemische Technologie,

Kernforschungsanlage Jülich G.m.b.H., Jülich, Germany, and Nuklear-Chemie und-Metallurgie G.m.b.H. (NUKEM), Hanau, Germany, February 1977.

C46. H. Tischer, Chemie und Verfahrenstechnik des HEAD ENDs bei der Wiederaufarbeitung von HTR-Brennelementen (Chemistry and process of the HEAD-ENDs from the reprocessing of HTR fuel elements), Jül-Spez-130 (in German), Institut für Chemische Technologie,

Kernforschungsanlage Jülich G.m.b.H., Jülich, Germany, October 1981.

C47. F. G. Bodewig and G. Kaiser, Dissolution of HTGR Fuel Particles In Nitric Acid Solutions, JÜL733-CT (GERHTR-36), Institut für Chemische Technologie, Kernforschungsanlage Jülich G.m.b.H., Jülich, Germany, February 1971, http://www.osti.gov/energycitations/servlets/purl/4031859-YTI4j9/4031859.pdf.

C48. H. D. Gerold, Uber die Entwicklung eines Verfahrens zur Rückgewinnung von Uran aus unbestrahlten beschichteten Kernbrennstoffteilchen (About the development of a procedure for recovery of uranium from unirradiated coated fuel particles), JÜL-741-RW (in German), Institut für Reaktorwerkstoffe, Kernforschungsanlage Jülich G.m.b.H., Jülich, Germany, March 1971, http://www.osti.gov/energycitations/servlets/purl/4772143-Pw68MF/.

C49. H.J.Riedel and W.Utecht, Einsatz der Chemie-Zellen in der Kernforschungsanlage Jülich fur die Wiederaufarbeitung bestrahlter HTGR-Brennelemente (Use of chemical cells in the Jülich Nuclear Research Center for reprocessing irradiated HTGR fuel elements), JÜL-777-CT (CONF-710618-3)(in German), Institut für Chemische Technologie, Kernforschungsanlage Jülich G.m.b.H., Jülich, Germany, July 1971, http://www.osti.gov/energycitations/servlets/purl/4699404-OepBQT/.

C50. O. Coenegracht, Entwicklung eines Verfahrens zur adsorptiven Protaktiniumabtrennung aus Reaktorbrennstoffloesungen (Development of a methods for adsorptive protactinium separation from reactor fuel solution), JÜL-822-CT (in German), Institut für Chemische Technologie, Kernforschungsanlage Jülich G.m.b.H., Jülich, Germany, January 1972, http://www.osti.gov/energycitations/servlets/purl/4591801-RQkpDv/.

C51. F.G. Bodewig, W. Johannisbauer, G. Kaiser, and P. Sckuhr, Component development for dissolution, feed solution adjustment, and extraction in JUPITER, GERHTR-66

(CONF-730468-1), Institut für Chemische Technologie, Kernforschungsanlage Jülich G.m.b.H., Jülich, Germany, April 1973, http://www.osti.gov/energycitations/servlets/purl/4349153$\mathrm{gPg} 0 \mathrm{qV} /$.

C52. U. Tillessen and E. Merz, "HTR-Brennstoffkreislauf - Technik und Strategie (HTR fuel cycleTechnology and Strategy)," pp. 271-279 (in German), Meeting of the working group of KTG and the Nuclear Research Establishment, Jülich, F.R. Germany, 12 November 1974, JÜL-Conf-14 (CONF-741169), HOBEG, Hanau, Germany, and Kernforschungsanlage Jülich G.m.b.H., Jülich, Germany, January 1975, http://www.osti.gov/energycitations/servlets/purl/4101310-6RJDqS/.

C53. D. Herz, R. Kankura, and U. Wenzel, Method of separating plutonium from the process streams of a reprocessing plant for HTR fuel elements, GERHTR-156 (translation of JÜL-1212), Institut für Chemische Technologie, Kernforschungsanlage Jülich G.m.b.H., Jülich, Germany, July 1975. 
C54. G. Ritter, Investigation of special resins for the extraction-chromatographic separation of Np and Pu from the process stream of a reprocessing plant for HTR fuel elements, GERHTR-181 (translation of KFA-ICT-IB-412-77), Institut für Chemische Technologie, Kernforschungsanlage Jülich G.m.b.H., Jülich, Germany, March 1977.

C55. S. Halaszovich et al., Interim storage and solidification for THOREX-type fission product solutions, GERHTR-84 (CONF-721107), Institut für Chemische Technologie, Kernforschungsanlage Jülich G.m.b.H., Jülich, Germany, 1972, http://www.osti.gov/energycitations/servlets/purl/4478293-QI3WXo/.

C56. S. Halaszovich, M. Laser, E. Merz, and D. Thiele, FIPS: a process for the solidification of fission product solutions using a drum drier in HTGR fuel reprocessing, GERHTR-149 (also presented as IAEA-SM-207/19 or CONF-760310-8, IAEA symposium on the management of radioactive waste, Vienna, Austria, 22 March 1976), Institut für Chemische Technologie, Kernforschungsanlage Jülich G.m.b.H., Jülich, Germany, March 1976.

C57. H. Barnert-Wiemer, Abgasbehandung bei der chlorierenden Wiederaufarbeitung graphithaltiger Kernbrenn- und Brutelemente aus Hochtemperaturreaktoren (Off-gas treatment in the reprocessing by chloination of graphite-bearing nuclear fuel and breeding elements from hightemperature reactors), JUL-826-CT (in German), Institut für Chemische Technologie, Kernforschungsanlage Jülich G.m.b.H., Jülich, Germany, Jauray 1972, http://www.osti.gov/energycitations/servlets/purl/4694460-UgtmW8/.

C58. M. Laser, H. Beaujean, and H. Vygen, AKUT: a process for separating aerosols, krypton, and tritium from the combustion waste gases in the reprocessing of high temperature fuel elements, GERHTR--60, Institut für Chemische Technologie, Kernforschungsanlage Jülich G.m.b.H., Jülich, Germany, 1973.

C59. M. Laser et al., Off-gas treatment and krypton disposal in HTGR-fuel element reprocessing, GERHTR-83 (CONF-721107), Institut für Chemische Technologie, Kernforschungsanlage Jülich G.m.b.H., Jülich, Germany, 1972, http://www.osti.gov/energycitations/servlets/purl/ 4480379-mffJMm/.

C60. H. Beaujean et al., Reinigung der Verbrennungsabgase bei der Wiederaufarbeitung von HTRBrennelementen (Purification of burner off-gases during reprocessing of irradiated HTR fuel elements), JUL-925-CT (in German), Institut für Chemische Technologie, Kernforschungsanlage Jülich G.m.b.H., Jülich, Germany, February 1973, http://www.osti.gov/energycitations/servlets/purl/4465018-wgWydj/.

C61. R. Boehnert, Treatment of volatile radionuclides in nuclear fuel reprocessing plants, GERHTR136 (translation of JÜ.L-1089-CT), Institut für Chemische Technologie, Kernforschungsanlage Jülich G.m.b.H., Jülich, Germany, July 1974.

C62. H. Schnez, M. Laser, and E. Merz, Tritium in reprocessing plants: a study of the inventory, behavior, and the possibilities of separation of the tritium isotope, GERHTR-139 (translation of JÜL-1099-CT), Institut für Chemische Technologie, Kernforschungsanlage Jülich G.m.b.H., Jülich, Germany, August 1974.

C63. J. Bohnenstingl et al., Cryogenic separation of krypton and xenon from dissolver off-gas, GERHTR-150 (also presented as IAEA-SM-207/20 or CONF-760310-9, IAEA symposium on the management of radioactive waste, Vienna, Austria, 22 March 1976), Institut für Chemische Technologie, Kernforschungsanlage Jülich G.m.b.H., Jülich, Germany, March 1976.

C64. H. Schnez, Treatment and separation of radioactive fission products tritium, rare gases and iodine in nuclear fuel reprocessing plants, GERHTR-158 (translation of JÜL-1223), Institut für Chemische Technologie, Kernforschungsanlage Jülich G.m.b.H., Jülich, Germany, July 1975. 
C65. J. Bohnenstingl et al., Separation of the fission product noble gases krypton and xenon from dissolver off-gas in reprocessing HTGR-fuel, GERHTR-162 (CONF-760822-21), Institut für Chemische Technologie, Kernforschungsanlage Jülich G.m.b.H., Jülich, Germany, August 1976.

C66. M. Laser, Separation, storage, and disposal of krypton-85: status and projects, GERHTR-177, Institut für Chemische Technologie, Kernforschungsanlage Jülich G.m.b.H., Jülich, Germany, September 1976.

C67. S.J. Mastera, Vapor equilibrium data for the systems $\mathrm{Ar}-\mathrm{N}_{2} /, \mathrm{Kr}-\mathrm{Ar}, \mathrm{Kr}-\mathrm{N}_{2}$, and $\mathrm{Xe}-\mathrm{Kr}$, as well as the liquidus lines of solid xenon and of solid krypton in liquid air component mixtures, GERHTR-180 (translation of JÜL-1380), Institut für Chemische Technologie, Kernforschungsanlage Jülich G.m.b.H., Jülich, Germany, 1976.

C68. P.C. Schmidt, Alternativen zur Verminderung der C-14-Emission bei der Wiederaufarbeitung von HTR-Brennelementen (Alternatives to reduce the $C$ - 14 emission from the reprocessing of HTR fuel elements), JÜl-1567 (in German), Institut für Chemische Technologie, Kernforschungsanlage Jülich G.m.b.H., Jülich, Germany, January 1979.

C69. M. Laser, H. Barnert-Wiemer, H. Beaujean, and H. Vygen, Possibilities and limitations of the introduction of electrostatic precipitators in reprocessing installations, GERHTR-176, Institut für Chemische Technologie, Kernforschungsanlage Jülich G.m.b.H., Jülich, Germany, no date given.

C70. J. Wolf, Ultimate storage of spent fuel elements from the AVR experimental nuclear power plant in the Asse Salt Mine, GERHTR-147 (translation of JÜL-1187), Institut für Chemische Technologie, Kernforschungsanlage Jülich G.m.b.H., Jülich, Germany, February 1975.

C71. E. Zimmer, P. Naefe, and H. Ringel, Development of a method and experimental installation for prefabricating HTGR fuels, GERHTR-59 (paper at CONF-730468), Institut für Chemische Technologie, Kernforschungsanlage Jülich G.m.b.H., Jülich, Germany, July 1973, http://www.osti.gov/energycitations/servlets/purl/4354817-KKMNKo/.

C72. H.J. Riedel, M Laser, E. Merz, and H. Schnez, Criteria for HTR-fuel reprocessing plant site evaluation, GERHTR--124 (IAEA-SM-188/20), Institut für Chemische Technologie, Kernforschungsanlage Jülich G.m.b.H., Jülich, Germany, 1974.

C73. H. Schnez, Zur Standortproblematik von Wiederaufarbeitungsanlagen für bestrahlte Kernbrennstoffe (Site selection for irradiated nuclear fuel reprocessing plants), Internal report KFA-ICT-404-IB-76 (in German), Institut für Chemische Technologie, Kernforschungsanlage Jülich G.m.b.H., Jülich, Germany, April 1976.

C74. B.G. Brodda, P. Filss, H. Kirchner, and U. Wenzel, Analysis and material accounting in the reprocessing of HTGR nuclear fuels, GERHTR-93 (translation of JÜL-1033-CT), Institut für Chemische Technologie, Kernforschungsanlage Jülich G.m.b.H., Jülich, Germany, December 1973.

C75. P.R. Lingen, Process for the identification of spherical fuel elements of the High-Temperature Reactor by means of emission spectrum analysis at 40 ATM helium, GERHTR-3 (translation of JÜL-671-RW.), Institut für Reaktorwerkstoffe, Kernforschungsanlage Jülich G.m.b.H., Jülich, Germany.

C76. B. Brodda, Determination of ${ }^{235} U$ burnup in the reprocessing of thorium-containing fuels, GERHTR-35 (translation of JÜL-715-CT), Institut für Chemische Technologie, Kernforschungsanlage Jülich G.m.b.H., Jülich, Germany, 1968, report as issued in German, Die Bestimmung des ${ }^{235} U$-Abbrandes bei der Wiederaufarbeitung thoriumhaltiger Kernbrennstoffe, December 1970, http://www.osti.gov/energycitations/servlets/purl/4030375-IFcyc3/. 
C77. R. Duwe, Determination of the residual fission metal content and burnup on spherical fuel elements with a uranium--thorium heavy metal insert by the gamma-spectrometric analysis of protactinium-233 and barium-140_Pebble bed reactors, GERHTR-89 (translation of JÜL-955RW), Institut für Reaktorwerkstoffe und Heisse Zellen, Kernforschungsanlage Jülich G.m.b.H., Jülich, Germany, May 1974.

C78. W. Litzow, Determination of the burnup, neutron fluence, fission product concentration, and heavy metal concentration in individual fuel elements, GERHTR-108 (KFA-ICT-IB--3/74), Institut für Chemische Technologie, Kernforschungsanlage Jülich G.m.b.H., Jülich, Germany, April 1974.

C79. A.M. dos Santos, Formation of actinides in irradiated HTGR fuel elements, GERHTR-168 (translation of JÜL-1284), Institut für Chemische Technologie, Kernforschungsanlage Jülich G.m.b.H., Jülich, Germany, March 1976.

C80. F. Daniels, Suggestions for a high-temperature pebble pile, N-1668b (MUC-FD-8), University of Chicago Metallurgical Laboratory, Chicago, IL, October 1944.

C81. C. R. McCullough et al., Summary report on design and development of high temperature gascooled power pile, MonN-383, Clinton Laboratories, Oak Ridge, TN, September 1947, http://www.osti.gov/energycitations/servlets/purl/4359623-lmW9Je/.

C82. H.K. Jackson, Preliminary report on the recovery of uranium from spent graphite-uranium fuel material, MonT-320, Clinton Laboratories, Oak Ridge, TN, June 1947, http://www.ornl.gov/info/reports/1947/3445605714885.pdf.

C83. L. P. Twichell et al., Comparison of various methods for the removal of uranium from carbon salvage, Y-352, Carbide and Carbon Chemicals Corp. Y-12 Plant, Oak Ridge, TN, February 1949, http://www.osti.gov/energycitations/servlets/purl/4371197-pUIP61/.

C84. E. T. McBee, T. DeVries, and L. R. Evans, Summary Report: The recovery of tuballoy from carbon parts, A-2703, Purdue Research Foundation and Purdue University, Lafayette, IN, November 1945, http://www.osti.gov/energycitations/servlets/purl/4374282-v9phKo/.

C85. C. R. McCullough and F. Daniels, Suggested research programs for power pile, ORNL/CF-4710-279 (CL-FD-46), Clinton Laboratories, Oak Ridge, TN, October 1947, http://www.ornl.gov/info/reports/1947/3445605714867.pdf.

C86. L. W. Fromm and H. E. Webb, "Recovery of uranium from graphite fuel units," Section III.J, pp. 19-20, Power Pile Division Quarterly Report for June, July and August 1948, ORNL-271, Oak Ridge National Laboratory, Oak Ridge, TN, September 1948, http://www.ornl.gov/info/reports/1948/3445603603223.pdf.

C87. L.W. Fromm, Recovering uranium from graphite by electrolytic graphite disintegration in nitric acid, ORNL-238, Oak Ridge National Laboratory, Oak Ridge, TN, February 1949, http://www.ornl.gov/info/reports/1949/3445603603731.pdf.

C88. A. Fitch, Jr., Reprocessing of Rover and Pluto fuels: Interim progress report, ORNL-2514, Oak Ridge National Laboratory, Oak Ridge, TN, May 1958, http://www.ornl.gov/info/reports/ 1958/3445605714876.pdf.

C88. A. Fitch, Jr., and L.M. Ferris, A tentative grind-leach process for Rover fuels, ORNL-2640, Oak Ridge National Laboratory, Oak Ridge, TN, December 1958, http://www.ornl.gov/info/ reports/1958/3445605995178.pdf.

C89. M.J. Bradley and L.M. Ferris, Reprocessing of Rover fuel: Laboratory development progress to April 1, 1959, ORNL-2741, Oak Ridge National Laboratory, Oak Ridge, TN, October 1959, http://www.ornl.gov/info/reports/1959/3445605994866.pdf. 
C90. L.M. Ferris and L.A. Kambach, Uranium recovery from KIWI fuel elements: Laboratory development, ORNL-3196, Oak Ridge National Laboratory, Oak Ridge, TN, December 1961, http://www.ornl.gov/info/reports/1961/3445605994940.pdf.

C91. F.L. Culler, Jr., Rover fuel processing: Summary to February 28, 1962, ORNL/TM-170, Oak Ridge National Laboratory, Oak Ridge, TN, 1962, http://www.ornl.gov/info/reports/ 1962/3445605484801.pdf.

C92. L.M. Ferris, A.H. Kibbey and K.S. Warren, Uranium recovery from KIWI-B fuel elements: Laboratory development Part II, ORNL-3283, Oak Ridge National Laboratory, Oak Ridge, TN, November `1962, http://www.ornl.gov/info/reports/1962/3445605995020.pdf.

C93. T.A. Gens, Laboratory development of chloride volatility processes for recovery of uranium from spent Rover fuel or from its combustion ash, ORNL-3376, Oak Ridge National Laboratory, Oak Ridge, TN, May 1963, http://www.ornl.gov/info/reports/1963/3445605995103.pdf.

C94. L.M. Ferris and K.S. Warren, Combustion-dissolution experiments with irradiated Rover (KIWIB4A) fuel, ORNL/TM-696, Oak Ridge National Laboratory, Oak Ridge, TN, October 1963, http://www.ornl.gov/info/reports/1963/3445605995095.pdf.

C95. L.E. McNeese and C.D. Scott, Recovery of uranium from graphite fuels by oxidation and fluorination: Part I-Design and initial operation of engineering-scale apparatus for Rover fuel, ORNL-3434, Oak Ridge National Laboratory, Oak Ridge, TN, October 1963, http://www.ornl.gov/info/reports/1963/3445605995186.pdf.

C96. T.A. Gens and T. B. Borne, Laboratory development of a process for recovering uranium from Rover fuel by combustion, liquid-phase chlorination with hexachloropropene, and aqueous extraction, ORNL-3435, Oak Ridge National Laboratory, Oak Ridge, TN, June 1963, http://www.ornl.gov/info/reports/1963/3445605994874.pdf.

C97. L.M. Ferris and K.S. Warren, Aqueous processes for uranium recovery from Rover fuel elements: Laboratory development Part III-Summary of the processes, ORNL-3459, Oak Ridge National Laboratory, Oak Ridge, TN, December 1963, http://www.ornl.gov/info/reports/1963/3445605995038.pdf.

C98. J.C. Bresee, Bibliography of Rover fuel processing and molten salt fluoride volatility process development studies at Oak Ridge National Laboratory, ORNL-TM-800, Oak Ridge National Laboratory, Oak Ridge, TN, April 1964, http://www.ornl.gov/info/reports/1964/3445605489799.pdf.

C99. L.M. Ferris, A burn-leach process for recovery of uranium from Rover fuel: Terminal report of laboratory development, ORNL-3763, Oak Ridge National Laboratory, Oak Ridge, TN, March 1965, http://www.ornl.gov/info/reports/1965/3445605698000.pdf.

C100. L.A. Decker, ICPP Laboratory studies on a combustion-nitric acid leach process for Rover fuel, IDO-14659, Phillips Petroleum Co., Idaho Falls, ID, November 1965.

C101. D.C. Kilian, A.P. Roeh, and B.R. Dickey, Description of the pilot plant for the headend processing of unirradiated Rover fuels, IN-1181, Idaho Nuclear Corp., Idaho Falls, ID, January 1968, http://www.osti.gov/energycitations/servlets/purl/4525969-b1vTiJ/.

C102. L.C. Borduin, D.C. Kilian, and A.P. Roeh, Development of a fluidized-bed burner for processing Rover fuel, IN-1423, Idaho Nuclear Corp., Idaho Falls, ID, January 1970, http://www.osti.gov/energycitations/servlets/purl/4081242-HNpYJP/.

C103. B.E. Paige and T.L. Evans, Process chemistry for burner product from graphite fuels containing niobium, IN-1484, Idaho Nuclear Corp., Idaho Falls, ID, January 1971, http://www.osti.gov/energycitations/servlets/purl/4740167-cduXp5/. 
C104. G. W. Hogg et al., Development of processes and equipment for recovering uranium from Rover-fuels-burner ash, ICP-1016, Allied Chemical Corp., Idaho Falls, ID, March 1973, http://www.osti.gov/energycitations/servlets/purl/4483540-1csa8D/.

C105. J.A. Rindfleisch, Stability of complexed Rover dissolver solutions containing high concentrations of niobium, fluoride-ion, and aluminum, ICP-1039, Allied Chemical Corp., Idaho Falls, ID, February 1974, http://www.osti.gov/energycitations/servlets/purl/4328568SwETV7/.

C106. J.S. Vavruska and J.A. Rindfleisch, Evaluation of a continuous solid bowl centrifuge for processing simulated Rover dissolver effluent, ICP-1073, Allied Chemical Corp., Idaho Falls, ID, June 1975, http://www.osti.gov/energycitations/servlets/purl/4162740-2igi3g/.

C107. A.G. Westra, Pilot plant verification of operating conditions for the Rover secondary burner, ICP-1147, Allied Chemical Corp., Idaho Falls, ID, March 1978, http://www.osti.gov/energycitations/servlets/purl/5031329-7Tk7ei/.

C108. S.A. Berrer, Pilot-plant development of a Rover waste calcination flowsheet, ICP-1148, Allied Chemical Corp., Idaho Falls, ID, April 1978, http://www.osti.gov/energycitations/ servlets/purl/6870657-BVb2K1/.

C109. H.S. Meyer, Rover process verification studies -- sintered metal filters blowback system, ICP-1165, Allied Chemical Corp., Idaho Falls, ID, August 1978, http://www.osti.gov/energycitations/servlets/purl/6639672-kqMrKL/.

C110. Environmental Statement: Rover Fuels Processing Facility-National Reactor Testing Station, Idaho, WASH-1512, U.S. Atomic Energy Commission, Washington, D.C., April 1972, http://www.osti.gov/energycitations/servlets/purl/4665751-gnc65M/.

C111. S. Stacey and J. Braun, Historic American Engineering Record, Idaho National Laboratory, Idaho Chemical Processing Plant, Fuel Reprocessing Complex, INL/EXT-06-11969 (HAER No. ID-33-H), Idaho National Laboratory, Idaho Falls, ID, December 2006, http://www.inl.gov/technicalpublications/Documents/3551472.pdf.

C112. J. R. Bower (Ed.), Idaho chemical programs annual technical report, fiscal year 1971, ICPICP-1006, Allied Chemical Corp., Idaho Falls, ID, January 1972, http://www.osti.gov/energycitations/servlets/purl/4687698-P3KGJT/.

C113. J. R. Bower (Ed.), Idaho chemical programs annual technical report, fiscal year 1972, ICPICP-1022, Allied Chemical Corp., Idaho Falls, ID, April 1973, http://www.osti.gov/energycitations/servlets/purl/4483539-4Q06Qi/.

C114. J. R. Bower (Ed.), Idaho chemical programs annual technical report, fiscal year 1973, ICPICP-1047, Allied Chemical Corp., Idaho Falls, ID, June 1974, http://www.osti.gov/energycitations/servlets/purl/4286945-m0RqAR/.

C115. J. R. Bower (Ed.), Idaho chemical programs annual technical report, fiscal year 1974, ICPICP-1063, Allied Chemical Corp., Idaho Falls, ID, January 1975, http://www.osti.gov/energycitations/servlets/purl/4236110-NPdY7C/.

C116. J. R. Bower and R. T. Struhs (Eds.), Idaho chemical programs annual technical report, fiscal year 1975, ICP-1086, Allied Chemical Corp., Idaho Falls, ID, June 1976, http://www.osti.gov/energycitations/servlets/purl/7268051-ksOdOF/.

C117. C. M. Slansky (Ed.), Technical Division quarterly progress report, October 1-December 31, 1976, ICP-1111, Idaho National Engineering Laboratory, Idaho Falls. ID, March 1977, http://www.osti.gov/energycitations/servlets/purl/7214153-Pxglha/. 
C118. C. M. Slansky (Ed.), Technical Division quarterly progress report, January 1-March 31, 1977, ICP-1117, Idaho National Engineering Laboratory, Idaho Falls. ID, May 1977, http://www.osti.gov/energycitations/servlets/purl/7212214-3dgIjD/.

C119. C. M. Slansky, B. R. Dickey, B. C. Musgrave, and K. L. Rohde, Technical Division quarterly progress report, April 1-June 30, 1977, ICP-1123, Idaho National Engineering Laboratory, Idaho Falls. ID, July 1977, http://www.osti.gov/energycitations/servlets/purl/7089547$7 \mathrm{a} 5 \mathrm{yVD} /$.

C120. C. M. Slansky, B. R. Dickey, B. C. Musgrave, and K. L. Rohde, Technical Division quarterly progress report, July 1-September 30, 1977, ICP-1132, Idaho National Engineering Laboratory, Idaho Falls. ID, October 1977, http://www.osti.gov/energycitations/servlets/purl/52678950a53VS/.

C121. C. M. Slansky (Ed.), Technical Division quarterly progress report, October 1-December 31, 1977, ICP-1141, Idaho National Engineering Laboratory, Idaho Falls. ID, February 1978, http://www.osti.gov/energycitations/servlets/purl/5058900-Di59Y6/.

C122. ICP-1150, Idaho National Engineering Laboratory, Idaho Falls. ID, July 1978, http://www.osti.gov/energycitations/servlets/purl/6708637-0SmJt0/.

C123. D. L. Plung (Ed.),, Technical Division quarterly progress report, April 1-June 30, 1978, ICP-1178, Idaho National Engineering Laboratory, Idaho Falls. ID, December 1978, http://www.osti.gov/energycitations/servlets/purl/6499531-MTuakg/.

C124. W.L. Greenstreet (Compiler), History of the Engineering Technology Division Oak Ridge National Laboratory 1944-1992, ORNL/M-2318, Oak Ridge National, Oak Ridge, TN, 1992, http://www.ornl.gov/info/reports/1992/3445605368241.pdf.

C125. Richard K. Genung, Robert L. Jolley, and John E. Mrochek (Compliers), A Brief History of the Chemical Technology Division, ORNL/M-2723, Oak Ridge National Laboratory, Oak Ridge, TN, May 1993, http://www.ornl.gov/ webworks/cppr/y2001/rpt/65193.pdf.

C126. G.M. Adamson et al., Metals and Ceramics Division History 1946-1996, ORNL/M-6589, Oak Ridge National Laboratory, Oak Ridge, TN, September 1997, http://www.ornl.gov/info/reports/1997/3445604465406.pdf.

C127. A.T. Gresky et al., Progress report: Laboratory Development of the Thorex Process, ORNL1367(Rev.), Oak Ridge National Laboratory, Oak Ridge, TN, December 1952, http://www.ornl.gov/info/reports/1952/3445603606024.pdf.

C128. John R. Parrott, Sr., "The Decontamination of Concrete Surfaces in Building 3019, Oak Ridge National Laboratory," CONF-800542-5(Draft), Concrete Decontamination Workshop, Battelle Conference Center, Seattle, Washington, May 28-29, 1980, http://www.osti.gov/energycitations/servlets/purl/5101358-iNjajT/.

C129. M.J. Bradley and L.M. Ferris, Recovery of uranium and thorium from graphite fuels ILaboratory development of a grind-leach process, ORNL-2761, Oak Ridge National Laboratory, Oak Ridge, TN, March 1960, http://www.ornl.gov/info/reports/1960/3445605995012.pdf.

C130. L.M. Ferris, A.H. Kibbey, and M.J. Bradley, Processes for recovery of uranium and thorium from graphite-base fuel elements-Part II, ORNL-3186, Oak Ridge National Laboratory, Oak Ridge, TN, November 1961, http://www.ornl.gov/info/reports/1961/3445605698224.pdf.

C131. R.E. Blanco, L.M. Ferris, and D.E. Ferguson, Aqueous processing of thorium fuels, ORNL-3219, Oak Ridge National Laboratory, Oak Ridge, TN, February 1962, http://www.ornl.gov/info/reports/1962/3445603644714.pdf. 
C132. W.L. Carter, Thorium utilization program: A survey of processing methods for thorium reactor fuels, ORNL/TM-241, Oak Ridge National Laboratory, Oak Ridge, TN, July 1962, http://www.ornl.gov/info/reports/1962/3445605488406.pdf.

C133. A.H. Kibbey and L.M. Ferris, U-Th recovery from pyrolytic carbon-coated carbide fuel particles by electrolysis in nitric acid, ORNL/TM-384, Oak Ridge National Laboratory, Oak Ridge, TN, September 1962, http://www.ornl.gov/info/reports/1962/3445605489557.pdf.

C134. R.E. Blanco et al., Aqueous processing of thorium fuels Part II, ORNL-3418, Oak Ridge National Laboratory, Oak Ridge, TN, May 1963, http://www.ornl.gov/info/reports/1963/3445605995194.pdf.

C135. L.M. Ferris et al., Combustion-dissolution experiments with irradiated graphite-base reactor fuel containing carbon-coated thorium-uranium dicarbide particles, ORNL/TM-688, Oak Ridge National Laboratory, Oak Ridge, TN, September 1963, http://www.ornl.gov/info/reports/1963/3445605495354.pdf.

C136. C.D. Scott, Recovery of uranium from graphite fuels by oxidation and fluorination II-Use of a mathematical analysis of the oxidation process in fixed bed to predict process conditions, ORNL-3456, Oak Ridge National Laboratory, Oak Ridge, TN, January 1964, http://www.ornl.gov/info/reports/1964/3445605994957.pdf.

C137. J.L. Cook and R.L. Hamner, The removal of uranium and thorium from fueled-graphite by chlorination, ORNL-3586, Oak Ridge National Laboratory, Oak Ridge, TN, April 1964, http://www.ornl.gov/info/reports/1964/3445605483474.pdf.

C138. T.A. Gens, Laboratory development of a process for chlorinating the combustion ash from graphite fuels containing $T h C_{2}$ and $U C_{2}$ and recovering the uranium by solvent extraction from a solution of the chlorination products, ORNL/TM-789, Oak Ridge National Laboratory, Oak Ridge, TN, May 1964, http://www.ornl.gov/info/reports/1964/3445605489977.pdf.

C139. J.R. Flanary et al., Hot-cell studies of aqueous dissolution processes for irradiated carbide reactor fuels, ORNL-3660, Oak Ridge National Laboratory, Oak Ridge, TN, September 1964, http://www.ornl.gov/info/reports/1964/3445602866851.pdf.

C140. L.M. Ferris and M.J. Bradley, Off-gases from reactions of uranium carbides with nitric acid at $90^{\circ} \mathrm{C}$, ORNL-3719, Oak Ridge National Laboratory, Oak Ridge, TN, December 1964, http://www.ornl.gov/info/reports/1964/3445605483296.pdf.

C141. J.T. Roberts et al., Reprocessing methods and costs for selected thorium-bearing reactor fuel types, ORNL-TM-1139, Oak Ridge National Laboratory, Oak Ridge, TN, May 1965, http://www.ornl.gov/info/reports/1965/3445601336912.pdf.

C142. H.O. Witte, Survey of head-end processes for the recovery of uranium and thorium from graphite-base reactor fuels, ORNL/TM-1411, Oak Ridge National Laboratory, Oak Ridge, TN, February 1966, http://www.ornl.gov/info/reports/1966/3445605499902.pdf.

C143.L.M. Ferris, Grind-leach process for graphite-base reactor fuels that contain coated particles: Laboratory development, ORNL-4110, Oak Ridge National Laboratory, Oak Ridge, TN, June 1967, http://www.ornl.gov/info/reports/1967/3445605158851.pdf.

C144.J.R. Flanary and J.H. Goode, Hot-cell evaluation of the grind-leach process I-Irradiated HTGR candidate fuels: Pyrocarbon-coated $(T h, U) C_{2}$ particles dispersed in graphite, ORNL-4117, Oak Ridge National Laboratory, Oak Ridge, TN, August 1967, http://www.ornl.gov/info/reports/1967/3445605158860.pdf.

C145.J.H. Goode and J.R. Flanary, Hot-cell evaluation of the grind-leach process II-Recovery or uranium and thorium from irradiated pyrolytic-carbon-coated sol-gel thoria-urania particles, 
ORNL-4213, Oak Ridge National Laboratory, Oak Ridge, TN, March 1968, http://www.ornl.gov/info/reports/1968/3445605158398.pdf.

C146.H.O. Witte (KFA-Jülich) and L.M. Ferris, Ball-milling of graphite-base reactor fuel, ORNL/TM-1412, Oak Ridge National Laboratory, Oak Ridge, TN, February 1966, http://www.ornl.gov/info/reports/1966/3445605499895.pdf.

C147.W. B. Tarpley and R. S. Winchester, Ultrasonic leaching of urania-impregnated graphite fuels, NYO-9851, Aeroprojects, Inc., West Chester, PA, April 1961, http://www.osti.gov/energycitations/servlets/purl/4022354-bKVIdF/.

C148.J.H. Goode and J.R. Flanary, Hot cell evaluation of the grind-leach process of irradiated pyrolytic carbon-coated sol-gel thoria-urania particles, ORNL/TM-1880, Oak Ridge National Laboratory, Oak Ridge, TN, May 1967, http://www.ornl.gov/info/reports/1967/3445605134066.pdf.

C149. A.L. Lotts and R.G. Wymer, Economics and technology of HTGR fuel recycle, ORNL/ TM-2377, Oak Ridge National Laboratory, Oak Ridge, TN, October 1968, http://www.ornl.gov/info/reports/1968/3445605131602.pdf.

C150. V.C.A. Vaughen, Head-end studies of SiC-coated HTGR fuels: Unirradiated Dragon Compact No. 8232, ORNL/TM-2389, Oak Ridge National Laboratory, Oak Ridge, TN, February 1969, http://www.ornl.gov/info/reports/1969/3445605131791.pdf.

C151. R.G. Wymer and A.L. Lotts, Status and Progress Report for Thorium Fuel Cycle Development for 1967 and 1968, ORNL-4429, Oak Ridge National Laboratory, Oak Ridge, TN, August 1969, http://www.ornl.gov/info/reports/1969/3445605994536.pdf.

C152. S.L. Reese et al., Feasibility study for reprocessing HTGR fuels on using the Nuclear Fuels Services Inc. reprocessing plant, GAMD-6360, Nuclear Fuels Services, Inc., West Valley, NY, and General Atomic Division, General Dynamics Corporation, San Diego, CA, January 1964, http://www.osti.gov/energycitations/servlets/purl/4229055-pCJ5bn/.

C153. J.J. Shefcik, Reprocessing HTGR hex block fuels at the Nuclear Fuel Services Plant, GAMD-7657, Gulf General Atomic Incorporated, San Diego, CA, January 1967, http://www.osti.gov/energycitations/servlets/purl/4808528-sVeINJ/.

C154. J.J. Shefcik, Central reprocessing plants for HTGR fuels, GAMD-8382, Gulf General Atomic Incorporated, San Diego, CA, January 1967, http://www.osti.gov/energycitations/servlets/purl/4831449-JwNE18/.

C155. J.J. Shefcik, Cost of reprocessing HTGR fuels in central plants of various capacities, GAMD8458, Gulf General Atomic Incorporated, San Diego, CA, January 1967, http://www.osti.gov/energycitations/servlets/purl/4505639-Q16CKh/.

C156. J.J. Shefcik, HTGR fuel reprocessing: Recovery of uranium from silicon carbide-coated fissile particles, GAMD-8615, Gulf General Atomic Incorporated, San Diego, CA, January 1968, http://www.osti.gov/energycitations/servlets/purl/4820793-EIL6Fh/.

C157. J.J. Shefcik, HTGR fuel reprocessing: Effects of including a silicon carbide coating on fertile fuel particles, GAMD-8661, Gulf General Atomic Incorporated, San Diego, CA, January 1968, http://www.osti.gov/energycitations/servlets/purl/4831448-jek7y2/.

C158. J.J. Shefcik, HTGR fuel reprocessing-Effects of some fuel design changes on reprocessing costs, GAMD-9089, Gulf General Atomic Incorporated, San Diego, CA, November 1968, http://www.osti.gov/energycitations/servlets/purl/4812162-taFVtO/. 
C159. L.H. Brooks, HTGR fuel reprocessing-Head-end treatment of experimental small scale HTGR fuel elements, GAMD-9260, Gulf General Atomic Incorporated, San Diego, CA, September 1969, http://www.osti.gov/energycitations/servlets/purl/4726224-qPaHfv/.

C160 L.H. Brooks, HTGR fuel reprocessing-Head-end treatment of experimental small scale HTGR fuel elements, GAMD-9260 Part II, Gulf General Atomic Incorporated, San Diego, CA, January 1970, http://www.osti.gov/energycitations/servlets/purl/4100310-jq45rx/.

C161. J.J. Shefcik, Interim storage of spent HTGR fuel, GAMD-9272, Gulf General Atomic, San Diego, CA, April 1969, http://www.osti.gov/energycitations/servlets/purl/4762954-m0Op4k/.

C162. K. J. Notz, An Overview of HTGR Fuel Recycle, ORNL/TM-4747, Oak Ridge National Laboratory, Oak Ridge, TN, January 1976, http://www.ornl.gov/info/reports/1976/ 3445605505726.pdf.

C163. O.C. Dean, R.E. Brooksbank, and A.L. Lotts, A New Process for Remote Preparation and Fabrication of Fuel Elements Containing Uranium-233 Oxide-Thorium Oxide, ORNL/TM-588, Oak Ridge National Laboratory, Oak Ridge, TN , June 1963, http://www.ornl.gov/info/reports/ 1963/3445603600547.pdf.

C164. J.D. Sease, A.L. Lotts, and F.C. Davis, Thorium-Uranium-233 Oxide (KILOROD) FacilityRod Fabrication Process and Equipment, ORNL-3539, Oak Ridge National Laboratory, Oak Ridge, TN, April 1964, http://www.osti.gov/energycitations/servlets/purl/4069413-lm7etO/.

C165. C.C. Haws et al., Summary of the Kilorod Project: a semiremote 10-KG/day demonstration of ${ }^{233} \mathrm{UO}_{x}-\mathrm{ThO} \mathrm{O}_{x}$ fuel-element fabrication by the ORNL Sol-Gel Vibratory-Compaction Method, ORNL-3681, Oak Ridge National Laboratory, Oak Ridge, TN, August 1965, http://www.ornl.gov/info/reports/1965/3445601344177.pdf.

C166. J.D. Sease, R.B. Pratt, and A.L. Lotts, Remote Fabrication of Thorium Fuels, ORNL/TM-1501, Oak Ridge National Laboratory, Oak Ridge, TN, April 1966, http://www.ornl.gov/info/ reports/1966/3445605491143.pdf.

C167. R.H. Rainey, Laboratory Development of a Pressurized Cation Exchange Process for Removing the Daughters of ${ }^{232} U$ from ${ }^{233} U$, ORNL-4731, Oak Ridge National Laboratory, Oak Ridge, TN, December 1972, http://www.ornl.gov/info/reports/1972/3445605995418.pdf.

C168. Section 2.3, "Preparation of ${ }^{233} \mathrm{UO}_{2}-\mathrm{ZrO}_{2}$ Microspheres ," pp. 213-214, and Sect. 6.1, "Preparation of $\mathrm{ThO}_{2}{ }^{-233} \mathrm{UO}_{2}$ Fuel for HTLTR," pp. xvii and 183-187, Chemical Technology Division Annual Progress Report for Period Ending May 31, 1969, ORNL-4422, Oak Ridge National Laboratory, Oak Ridge, TN, October 1969, http://www.ornl.gov/info/reports/1969/3445602515375.pdf.

C169. "Coating of $\left({ }^{233}\right.$ U-Th) $\mathrm{O}_{2}$ Fuel," p. 207, Metals and Ceramics Division Annual Progress Report for Period ending June 30, 1969, ORNL-4470, Oak Ridge National Laboratory, Oak Ridge, TN, October 1969, http://www.ornl.gov/info/reports/1969/3445602859244.pdf.

C170. R.A. Olstad et al., An irradiation test of candidate HTGR recycle fuels in the $H-1$ and $H-2$ capsules, ORNL/TM-4397, Oak Ridge National Laboratory, Oak Ridge, TN, July 1974, http://www.ornl.gov/info/reports/1974/3445605502113.pdf.

C171. E.L. Long, Jr., R.B. Fitts, and F.J. Homan, Fabrication of ORNL Fuel Irradiated in the Peach Bottom Reactor and Postirradiation Examination of Recycle Test Elements 7 and 4, ORNL/TM-4477, Oak Ridge National Laboratory, Oak Ridge, TN, September 1974, http://www.ornl.gov/ webworks/cppr/y2001/rpt/112290.pdf. 
C172. F. J. Homan and E. L. Long, Jr., Irradiation Performance of HTGR Recycle Fissile Fuel, ORNL/TM-5502, Oak Ridge National Laboratory, Oak Ridge, TN, August 1976, http://www.ornl.gov/info/reports/1976/3445603218881.pdf.

C173. F.J. Homan et al., Development of a Fissile Particle for HTGR Fuel Recycle, ORNL/TM-5602, Oak Ridge National Laboratory, Oak Ridge, TN, December 1976, http://www.ornl.gov/info/reports/1976/3445602856229.pdf.

C174. T.N. Tiegs and E.L. Long, Jr., Postirradiation Examination of Recycle Test Elements from the Peach Bottom Reactor, ORNL-5422, Oak Ridge National Laboratory, Oak Ridge, TN, December 1978, http://www.ornl.gov/info/reports/1978/3445600214006.pdf.

C175. R. D. Modrow et al., Design criteria for an HTGR reference fuel reprocessing plant, CT-1133, Idaho Nuclear Corp., Idaho Falls, ID, December 1968, http://www.osti.gov/energycitations/servlets/purl/5386528-k2TMr5/.

C176. An Evaluation of Advanced Converter Reactors, WASH-1087, Advanced Converter Task Force, U.S. Atomic Energy Commission, January 1969, http://www.osti.gov/energycitations/servlets/purl/4775766-5aJLe5/.

C177. J.W. Anderson, S.E. Bolt, and J.M. Chandler, Safety Analysis of the Thorium-Uranium Recycle Facility, ORNL-4278, Oak Ridge National Laboratory, Oak Ridge, TN, May 1969, http://www.ornl.gov/info/reports/1969/3445605743755.pdf.

C178. National HTGR Fuel Recycle Development Program Plan, ORNL-4702, Oak Ridge National Laboratory, Oak Ridge, TN, and Gulf General Atomic, San Diego, CA, December 1970, http://www.ornl.gov/info/reports/1971/3445605150608.pdf. (NOTE: A 1973 Revision 1 to this plan reportedly was written but cannot be found except as a pen-and-ink mark-up draft in ORNL Laboratory Rrecords; a Revision 3 is also cited as a reference in later documents by GA and ICPP but also cannot be found.)

C179. AEC Conceptual High-Temperature Gas-cooled Reactor (HTGR) Fuel Processing Plant, WASH-1152, Idaho Nuclear Corp., Idaho Fall, Idaho, January 1970, http://www.osti.gov/energycitations/servlets/purl/4113739-jEr3F8/.

C180. Final Environmental Statement: HTGR Fuel Refabrication Pilot Plant Oak Ridge National Laboratory, Oak Ridge, Tennessee, WASH-1533 (Final), U.S. Atomic Energy Commission, Washington, DC, August 1974, http://www.osti.gov/energycitations/servlets/purl/4263794RCQquI/ and http://www.ornl.gov/info/reports/1974/3445605994775.pdf.

C181. Final environmental statement: HTGR fuels reprocessing facilities, National Reactor Testing Station, Idaho, WASH-1534 (Final), U.S. Atomic Energy Commission, Washington, D.C., August 1974, http://www.osti.gov/energycitations/servlets/purl/4250718-y2NVVG/.

C182. S.R. McNeany, NOMUF - a computer code for calculating material flows in HTGR FRPP, ORNL/CF-74-9-14 (GCR: 74-23), Oak Ridge National Laboratory, Oak Ridge, TN, September 1974, http://www.ornl.gov/info/reports/1974/3445605698135.pdf.

C183. J.D. Jenkins, Solid waste handling policy for HTGR-FRPP, ORNL/CF-74-11-41 (GCR: 74-33), Oak Ridge National Laboratory, Oak Ridge, TN, November 1974, http://www.ornl.gov/info/ reports/1974/3445605698126.pdf.

C184. John D. Sease and A.L. Lotts, Development of Processes and Equipment for the Refabrication of HTGR Fuels, ORNL/TM-5334, Oak Ridge National Laboratory, Oak Ridge, TN, June 1976, http://www.ornl.gov/info/reports/1976/3445605558704.pdf. 
C185. B.J. Baxter, G.E. Benedict, and R.D. Zimmerman, Flowsheet development for HTGR fuel reprocessing, GA-A13808 (CONF-760823-6), General Atomic Company, San Diego, CA, April 1976, http://www.osti.gov/energycitations/servlets/purl/7357794-dDkpge/.

C186. R.W. Glass et al., HTGR Head-End Processing: A Preliminary Evaluation of Processes for Decontaminating Burner Off-Gas, ORNL/TM-3527, Oak Ridge National Laboratory, Oak Ridge, TN, July 1972, http://www.ornl.gov/info/reports/1972/3445605144359.pdf.

C187. M.E. Whatley, Performance of the KALC Process, ORNL-4859, Oak Ridge National Laboratory, Oak Ridge, TN, April 1973, http://www.ornl.gov/info/reports/1972/ 3445605144359.pdf.

C188. P.A. Haas, HTGR Fuel Reprocessing: A Whole-Block Burner with Recycle of Cooled Gas for Temperature Control, ORNL/TM-4519, Oak Ridge National Laboratory, Oak Ridge, TN, August 1974, http://www.ornl.gov/info/reports/1974/3445600499538.pdf.

C189. J.W. Snider and D.C. Watkin, An Evaluation of HTGR Primary Burning, ORNL/ TM-4520, Oak Ridge National Laboratory, Oak Ridge, TN, November 1974, http://www.ornl.gov/info/reports/1974/3445600499538.pdf.

C190. R.D. Ackley, Removal of Radon-220 from HTGR Fuel Reprocessing and Refabrication Off-Gas Streams by Adsorption (Based on a Literature Survey), ORNL/TM-4883, Oak Ridge National Laboratory, Oak Ridge, TN, April 1975, http://www.ornl.gov/info/reports/ 1975/3445605506547.pdf.

C191. C.L. Fitzgerald, V.C.A. Vaughen, K.J. Notz, and R.S. Lowrie, Head-End Reprocessing Studies

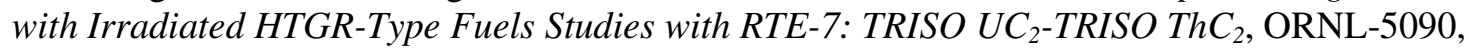
Oak Ridge National Laboratory, Oak Ridge, TN, November 1975, http://www.ornl.gov/info/reports/1975/3445605995491.pdf.

C192. R.W. Glass, T.M. Gilliam, and V.L. Fowler, An Empirical Model for Calculating Vapor-Liquid Equilibrium and Associated Phase Enthalpy for the $\mathrm{CO}_{2}-\mathrm{O}_{2}-\mathrm{Kr}$-Xe System for Application to the KALC Process, ORNL/TM-4947, Oak Ridge National Laboratory, Oak Ridge, TN, January 1976, http://www.ornl.gov/info/reports/1976/3445605506627.pdf.

C193. K.H. Lin, Characteristics of Radioactive Waste Streams Generated In HTGR Fuel Reprocessing, ORNL/TM-5096, Oak Ridge National Laboratory, Oak Ridge, TN, January 1976, http://www.ornl.gov/info/reports/1976/3445605508992.pdf.

C194. R.W. Glass, H.W.R. Beaujean, V.L. Fowler, T.M. Gilliam, D.J. Inman, and D.M. Levins, Krypton Absorption in Liquid $\mathrm{CO}_{2}(K A L C)$ : Campaign II in the Experimental Engineering Section Off-Gas Decontamination Facility, ORNL/TM-5095, Oak Ridge National Laboratory, Oak Ridge, TN, February 1976, http://www.ornl.gov/info/reports/1976/3445605508466.pdf.

C195. J.C. Mullins, An Equilibrium Stage Model of the KALC Process, ORNL/TM-5099, Oak Ridge National Laboratory, Oak Ridge, TN, August 1976, http://www.ornl.gov/info/reports/ 1976/3445605508956.pdf.

C196. R.W. Glass and R.E. Barker, A Computer Model for the KALC Process Studies in the ORGDP Off-Gas Decontamination Pilot Plant, ORNL/TM-5457, Oak Ridge National Laboratory, Oak Ridge, TN, September 1976, http://www.ornl.gov/info/reports/1976/3445602847347.pdf.

C197. V.C.A. Vaughen, On the separation of silicon carbide-coated fertile and fissile particles by gas classification, ORNL/TM-5091, Oak Ridge National Laboratory, Oak Ridge, TN, July 1976, http://www.ornl.gov/info/reports/1976/3445605508518.pdf.

C198. C.E. Lamb, C.L. Fitzgerald, and V.C.A. Vaughen, Behavior of fission product iodine in the head-end reprocessing of HTGR fuel:-Iodine-129 studies (Series I), ORNL/TM-6642, Oak 
Ridge National Laboratory, Oak Ridge, TN, July 1979, http://www.ornl.gov/info/reports/ 1979/3445605698019.pdf.

C199. K.J. Notz et al., Processes for the control of ${ }^{14} \mathrm{CO}_{2}$ during reprocessing, ORNL/TM-7338, Oak Ridge National Laboratory, Oak Ridge, TN, July 1980, http://www.ornl.gov/info/reports/1980/3445605698215.pdf.

C200. B.J. Baxter et al., Fluidized-bed combusters used in HTGR fuel reprocessing, Gulf-GA-A12285 (CONF-721056-1), Gulf General Atomic Incorporated, San Diego, CA, October 1972, http://www.osti.gov/energycitations/servlets/purl/4634001-PMsjBS/.

C201. L.H. Brooks et al., Carbon-14 in the HTGR Fuel Cycle, GA-A13174, General Atomic Company, San Diego, CA, November 1974, http://www.osti.gov/energycitations/ servlets/purl/4233769-9JSTvK/.

C202. C.A. Heath and M.E. Spaeth, Reprocessing development for HTGR fuels, GA-A13279 (CONF-750424-2), General Atomic Company, San Diego, CA, February 1975, http://www.osti.gov/energycitations/servlets/purl/4245096-6vKEXp/.

C203. D.T. Pence, J.J. Shefcik, and C.A. Heath, Waste management considerations in HTGR recycle operations, GA-A13708 (CONF-751101-59), General Atomic Company, San Diego, CA, November 1975, http://www.osti.gov/energycitations/servlets/purl/4133630-hTluMh/.

C204. L.H. Brooks, C.A. Heath, and J.J. Shefcik, HTGR fuel reprocessing technology, GA-A13807 (CONF-760823-3), General Atomic Company, San Diego, CA, April 1976, http://www.osti.gov/energycitations/servlets/purl/7268052-kRDabd/.

C205. B.J. Baxter, G.E. Benedict, and R.D. Zimmerman, Flowsheet development for HTGR fuel reprocessing, GA-A13808 (CONF-760823-6), General Atomic Company, San Diego, CA, April 1976.

C206. R.M. Burgoyne, Interim design status and operational report for remote handling fixtures: Primary and secondary burners, GA-A14125, General Atomic Company, San Diego, CA, December 1976, http://www.osti.gov/energycitations/servlets/purl/7318481-G9gygj/.

C207 A.S. Ballard: Interim design status and operational report for semiremote handling fixtures: Size reduction system, GA-A14126, General Atomic Company, San Diego, CA, February 1977, http://www.osti.gov/energycitations/servlets/purl/7314367-lbU6Bd/.

C208. D.T. Young, Fluidized combustion of beds of large dense particles in reprocessing HTGR fuel, GA-A14327 (CONF-770804-3), General Atomic Company, San Diego, CA, March 1977, http://www.osti.gov/energycitations/servlets/purl/7255868-qAx5qB/.

C209. J.S. Rode, A design evaluation of the 40-cm (16-inch) primary burner system, GA-A14452, General Atomic Company, San Diego, CA, June 1977, http://www.osti.gov/ energycitations/servlets/purl/7089548-FiDGfM/.

C210. E.J. Cook and P.C. Richards, Initial performance evaluation of major components in the headend reprocessing solids handling system, GA-A14508, General Atomic Company, San Diego, CA, September 1977, https://www.osti.gov/src/servlets/purl/5323651-V2sf7P/5323651.PDF.

C211. J.S. Rode, Design evaluation of the 20-cm (8-inch) secondary burner system, GA-A14510, General Atomic Company, San Diego, CA, August 1977, http://www.osti.gov/ energycitations/servlets/purl/7211277-hv6R8L/.

C212. W.S. Rickman, Process development report-0. 20-m secondary burner system, GA-A14542, General Atomic Company, San Diego, CA, September 1977, http://www.osti.gov/ energycitations/servlets/purl/5323650-9EPfTC/. 
C213. E.J. Cook and P.C. Richards, Selection and testing of on-line samplers for head-end reprocessing, GA-A14634, General Atomic Company, San Diego, CA, October 1977, http://www.osti.gov/energycitations/servlets/purl/5415936-NDoA6J/.

C214. R.T. Stula, D.T. Young, and J.S. Rode, 0. 20-m (8-in. ) primary burner development report, GA-A14643, General Atomic Company, San Diego, CA, December 1977, http://www.osti.gov/energycitations/servlets/purl/5246513-HWVBKa/.

C215. J.W. Baer et al., Interim design report: Fuel particle crushing, GA-A14675, General Atomic Company, San Diego, CA, November 1977, http://www.osti.gov/energycitations/ servlets/purl/5066354-ICgvVx/.

C216. J.B. Strand and G.T. Cramer, HTGR fuel element size reduction system: Interim development report, GA-A14838, General Atomic Company, San Diego, CA, June 1978, http://www.osti.gov/energycitations/servlets/purl/6672406-kSf2DJ/.

C217. J.B. Strand, Design evaluation of the HTGR fuel element size reduction system, GA-A14859, General Atomic Company, San Diego, CA, June 1978, http://www.osti.gov/ energycitations/servlets/purl/6869027-k5HvaW/.

C218. J.B. Strand, Particle classifier for HTGR fuel reprocessing: Engineering-scale unit interim development report, GA-A14930, General Atomic Company, San Diego, CA, July 1978, http://www.osti.gov/energycitations/servlets/purl/6596664-loVLTI/.

C219. N.W. Johanson, HTGR fuel particle crusher design evaluation, GA-A14957, General Atomic Company, San Diego, CA, October 1978, http://www.osti.gov/energycitations/ servlets/purl/6292508-ajywE1/.

C220. J.W. Baer and J.B. Strand, Interim development report: Engineering-scale HTGR fuel particle crusher, GA-A15073, General Atomic Company, San Diego, CA, September 1978, http://www.osti.gov/energycitations/servlets/purl/6596656-cUmg91/.

C221. Project Staff, General Atomic HTGR fuel reprocessing pilot plant: Results of initial sequential equipment operation, GA-A15081, General Atomic Company, San Diego, CA, September 1978, http://www.osti.gov/energycitations/servlets/purl/6567660-rPC7Ba/.

C222. W.S. Rickman, Process development report-0. 20-m primary burner system, GA-A15088, General Atomic Company, San Diego, CA, September 1978, http://www.osti.gov/ energycitations/servlets/purl/6567646-hj59t2/.

C223. J.B. Strand et al., HTGR fuel reprocessing pilot plant: Results of the sequential equipment operation, GA-A15343, General Atomic Company, San Diego, CA, May 1979, http://www.osti.gov/energycitations/servlets/purl/5955788-ECa43c/.

C224. J.W. Baer, HTGR fuel particle crusher-Mark 2 design, GA-A15447, General Atomic Company, San Diego, CA, June 1979, http://www.osti.gov/energycitations/servlets/purl/ 5929824-5C6FH4/.

C225. U-Sun Park, Thermal aspects in the design of an HTGR fuel reprocessing plant, GA-A15487 (CONF-790822-9), General Atomic Company, San Diego, CA, August 1979, http://www.osti.gov/energycitations/servlets/purl/5912681-dbCK1d/.

C226. W.S. Rickman, Combustion of carbon fines by above-bed recycle in an atmospheric fluidized bed burner, GA-A15540 (CONF-791108), General Atomic Company, San Diego, CA, August 1979, http://www.osti.gov/energycitations/servlets/purl/5870597-KG1eVc/. 
C227. W.B. Palmer, Breaking silicon carbide coated unirradiated Ft. St. Vrain fuel particles by jet grinding, ICP-1043, Allied Chemical Corp., Idaho Falls, ID, April 1974, http://www.osti.gov/ energycitations/servlets/purl/4292278-QX7uFN/.

C228. M.K. Valentine, Development of a gas classification method for separating Ft. St. Vrain TRISO-TRISO fuel particles, ICP-1051, Allied Chemical Corp., Idaho Falls, ID, April 1974, http://www.osti.gov/energycitations/servlets/purl/4297602-RWQ006/.

C229. G.E. Bingham and T.K. Evans, Final safety analysis report for the irradiated fuels storage facility, ICP-1052, Allied Chemical Corp., Idaho Falls, ID, January 1976, http://www.osti.gov/energycitations/servlets/purl/4095959-Hsfukn/.

C230. W.B. Palmer, Interim experimental results: Breaking silicon carbide coatings on Ft. St. Vrain fertile particles using a gas jet, ICP-1062, Allied Chemical Corp., Idaho Falls, ID, March 1975, http://www.osti.gov/energycitations/servlets/purl/4233669-G62pO9/.

C231. W.B. Palmer, Interim experimental results: Primary graphite burner testing without fines recycle, ICP-1068, Allied Chemical Corp., Idaho Falls, ID, June 1975.

C232. W.B. Palmer, Interim results: Fines recycle testing using the 4-inch diameter primary graphite burner, ICP-1069, Allied Chemical Corp., Idaho Falls, ID, May 1975, http://www.osti.gov/ energycitations/servlets/purl/4213910-w4LYao/.

C233. W.B. Palmer, Experimental testing of the double-roll crusher for breaking silicon carbide coatings on unirradiated Ft. St. Vrain fuel particles, ICP-1070, Allied Chemical Corp., Idaho Falls, ID, April 1975, http://www.osti.gov/energycitations/servlets/purl/4233668-NhiiB7/.

C234. G.W. Hogg et al., Interim results: Development of a head-end process for recovering uranium and thorium from crushed Ft. St. Vrain fuel, ICP-1074, Allied Chemical Corp., Idaho Falls, ID, October 1975, http://www.osti.gov/energycitations/servlets/purl/4127951-FxSAW8/.

C235. D. deLesdernier, Pneumatic classification of Fort St. Vrain fuel particles, GA-A13135, General Atomic Company, San Diego, CA, June 1975, http://www.osti.gov/energycitations/ servlets/purl/4178690-tLwFjM/.

C236. P.C. Richards and E.J. Cook, Pneumatic conveying in HTGR nuclear fuel reprocessing, GA-A14705 (CONF-780697-1), General Atomic Company, San Diego, CA, April 1978, http://www.osti.gov/energycitations/servlets/purl/6654637-9FhXbQ/.

C237. J.M. McNair, Design evaluation: Pneumatic transport and classification, GA-A14860, General Atomic Company, San Diego, CA, October 1979, http://www.osti.gov/energycitations/ servlets/purl/5748586-owkvJ7/.

C238. L.J. Olguin, Continuous solvent extraction feed adjustment for HTGR fuel reprocessing: Interim development report, GA-A15014, General Atomic Company, San Diego, CA, June 1978, http://www.osti.gov/energycitations/servlets/purl/6703486-xN8MOf/.

C239. R.G. Wilbourne, Solvent extraction in HTGR reprocessing: Interim development report II, GA-A15030, General Atomic Company, San Diego, CA, July 1978, http://www.osti.gov/ energycitations/servlets/purl/6567661-SLmrce/.

C240. H.H. Yip and L.J. Olguin, Dissolution in HTGR fuel reprocessing:-interim development report, GA-A15092, General Atomic Company, San Diego, CA, August 1978, http://www.osti.gov/ energycitations/servlets/purl/6616109-U3tNFw/.

C241. H.H. Yip, General Atomic Reprocessing Pilot Plant: Engineering-scale dissolution system description, GA-A15298, General Atomic Company, San Diego, CA, April 1979, http://www.osti.gov/energycitations/servlets/purl/6154412-aasmHy/. 
C242. R.G. Wilbourne and L.J. Olguin, Continuous solvent extraction feed preparation in thorium fuel reprocessing, GA-A15374 (CONF-790602-85), General Atomic Company, San Diego, CA, July 1979, http://www.osti.gov/energycitations/servlets/purl/5988389-OqgCMK/.

C243. F.J. Furman, J.T. Meador, and J.D. Sease, Microsphere Handling Techniques, ORNL/ TM-2782, Oak Ridge National Laboratory, Oak Ridge, TN, May 1970, http://www.ornl.gov/info/reports/1970/3445605138071.pdf.

C244. W.J. Lackey et al., Assessment of coater size for the fuel refabrication prototype plant, ORNL/TM-4567, Oak Ridge National Laboratory, Oak Ridge, TN, July 1974, http://www.ornl.gov/info/reports/1974/3445605500384.pdf.

C245. R.R. Suchomel and W.J. Lackey, Device for Sampling HTGR Recycle Fuel Particles, ORNL/TM-5739, Oak Ridge National Laboratory, Oak Ridge, TN, March 1977, http://www.ornl.gov/info/reports/1977/3445605097775.pdf.

C246. W.H. Pechin, W.J. Lackey, J.D. Sease, and W.P. Eatherly, Inspection of High-Temperature Gas-Cooled Reactor Recycle Fuel, ORNL-5165, Oak Ridge National Laboratory, Oak Ridge, TN, June 1977, http://www.ornl.gov/info/reports/1977/3445605159351.pdf.

C227. J.E. Mack and D.R. Johnson, Development of a Pneumatic Transfer System for HTGR Recycle Fuel Particles, ORNL/TM-6169, Oak Ridge National Laboratory, Oak Ridge, TN, February 1978, http://www.ornl.gov/info/reports/1978/3445605510220.pdf.

C248. R.R. Suchomel, R.J. Braatz, B.J. Bolfing, and J.L. Heck, Design Study for a 24-cm HTGR Microsphere Coating Furnace, ORNL/TM-6321, Oak Ridge National Laboratory, Oak Ridge, TN, May 1978, http://www.ornl.gov/info/reports/1978/3445605557304.pdf.

C249. R.R. Suchomel et al., Design and Operation of Equipment Used to Develop Remote Coating Capability for HTGR Fuel Particles, ORNL/TM-6581, Oak Ridge National Laboratory, Oak Ridge, TN, December 1978, http://www.ornl.gov/info/reports/1978/3445605515546.pdf.

C250. J.E. Rushton, E.J. Allen, M.M. Chile, and J.D. Jenkins, Design and Evaluation of an On-Line Fuel Rod Assay Device for an HTGR Fuel Refabrication Plant, ORNL/TM-6960, Oak Ridge National Laboratory, Oak Ridge, TN, November 1979, http://www.ornl.gov/info/reports/ 1979/3445605556975.pdf.

C251. J.E. Mack, R.R. Suchomel, and P. Angelini, Development of Nuclear Fuel Microsphere Handling Techniques and Equipment, ORNL/TM-7143, Oak Ridge National Laboratory, Oak Ridge, TN, January 1980, http://www.ornl.gov/info/reports/1980/3445605555431.pdf.

C252. C.K. Bayne and P. Angelini, Evaluation of Gravimetric and Volumetric Dispensers of Particles of Nuclear Material, ORNL/TM-7684, Oak Ridge National Laboratory, Oak Ridge, TN, August 1981, http://www.ornl.gov/info/reports/1981/3445605511693.pdf.

C253. D.J. Downing and Milton Bailey, Production Control in HTGR Fuel Rod Fabrication, ORNL/CSD/TM-87, Oak Ridge National Laboratory, Oak Ridge, TN, June 1979, http://www.ornl.gov/info/reports/1979/3445605994510.pdf.

C254. M.S. Judd, J.E. Van Cleve, Jr., and W.T. Rainey, Jr., Recovery of Perchloroethylene Scrubbing Medium Generated in the Refabrication of High-Temperature Gas-Cooled Reactor Fuel, ORNL/TM-5620, Oak Ridge National Laboratory, Oak Ridge, TN, November 1976, http://www.ornl.gov/info/reports/1976/3445605994619.pdf.

C255. K.H. Lin, Process Alternatives for HTGR Fuel Reprocessing Wastes: An Engineering Evaluation, ORNL/TM-5823, Oak Ridge National Laboratory, Oak Ridge, TN, May 1977, http://www.ornl.gov/info/reports/1977/3445605510943.pdf. 
C256. D.D. Jensen. L.J. Olguin, and R.G. Wilbourn, Test results from the GA Technologies engineering-scale off-gas treatment system, GA-A17634 (CONF-840806-1), GA Technologies, San Diego, CA, June 1984, http://www.osti.gov/energycitations/servlets/purl/6716780$\mathrm{qWjADb} /$.

C257. F.J. Furman, R.B. Pratt, and A.L. Lotts, Prediction of the economically optimum time to initiate recycle for the High-Temperature Gas-Cooled Reactor industry using computer program DELAY, ORNL/TM-2704, Oak Ridge National Laboratory, Oak Ridge, TN, December 1969, http://www.ornl.gov/info/reports/1969/3445605137768.pdf.

C258. L.L. Bennett and W.E. Thomas, Cost Penalties associated with Cross-Mixing of HTGR Particle Types during Fuel Reprocessing, ORNL/TM-3852, Oak Ridge National Laboratory, Oak Ridge, TN, December 1972, http://www.ornl.gov/info/reports/1972/3445605147622.pdf.

C259. W.E. Thomas, Development of a Procedure for Evaluating the Economics of Process Options in Commercial HTGR Fuel Recycle, ORNL/TM-5125, Oak Ridge National Laboratory, Oak Ridge, TN, May 1976, http://www.ornl.gov/info/reports/1976/3445605508723.pdf.

C260. W. Davis, Jr. et al., Correlation of radioactive waste treatment costs and the environmental impact of waste effluents in the nuclear fuel cycle-Reprocessing of High-Temperature Gascooled Reactor fuel containing U-233 and thorium, ORNL/NUREG/TM-4, Oak Ridge National Laboratory, Oak Ridge, TN, May 1976, http://www.ornl.gov/info/reports/1976/3445605698046.pdf.

C261. V.A. DeCarlo, Design of a System for the Nondestructive Assay of ${ }^{233} U$ in Waste Drums, ORNL/TM-4249, Oak Ridge National Laboratory, Oak Ridge, TN, August 1973, http://www.ornl.gov/ webworks/cppr/y2001/rpt/110868.pdf.

C262. S.R. McNeany, R.W. Knoll, and J.D. Jenkins, Design and Evaluation of a Nondestructive Fissile Assay Device for HTGR Fuel Samples, ORNL/TM-6610, Oak Ridge National Laboratory, Oak Ridge, TN, February 1979, http://www.ornl.gov/info/reports/1979/3445605515608.pdf.

C263. J.A. Carpenter, Jr. et al., Material Control and Accountability Aspects of Safeguards for the USA ${ }^{233}$ U/TH Fuel Recycle Plant, ORNL/TM-6645, Oak Ridge National Laboratory, Oak Ridge, TN, January 1979, http://www.ornl.gov/info/reports/ 1979/3445605515528.pdf.

C264. S.R. McNeany and J.D. Jenkins, Criticality Considerations for ${ }^{233}$ U Fuels in an HTGR Fuel Refabrication Facility, ORNL/TM-6136, Oak Ridge National Laboratory, Oak Ridge, TN, January 1978, http://www.ornl.gov/info/reports/1978/3445605505478.pdf.

C265. J.E. Selle, Chemical and Physical Considerations of the Use of Nuclear Fuel Spikants for Deterrence, ORNL/TM-6412, Oak Ridge National Laboratory, Oak Ridge, TN, October 1978, http://www.ornl.gov/info/reports/1978/3445605514468.pdf.

C266. J.E. Selle et al., Practical Consideration of Nuclear Fuel Spiking for Proliferation Deterrence, ORNL/TM-6483, Oak Ridge National Laboratory, Oak Ridge, TN, October 1978, http://www.ornl.gov/info/reports/1978/3445605514823.pdf.

C267. L.H. Brooks, The use of spikants in HTGR fuel and their effect on costs, GA-A15377, General Atomic Company, San Diego, CA, May 1979, http://www.osti.gov/energycitations/ servlets/purl/6110547-EDceNa/.

C268. P.R. Kasten et al., Research and Development Requirements for the Recycle of Bred Fuels in Uranium and Thorium Fuel Cycles, ORNL/TM-6504, Oak Ridge National Laboratory, Oak Ridge, TN, May 1979, http://www.ornl.gov/info/reports/1979/3445600609054.pdf. 
C269. Thorium utilization program quarterly progress report for the period ending August 31, 1974, GA-A13178, General Atomic Company, San Diego, CA, October 1974, http://www.osti.gov/ energycitations/servlets/purl/4213912-0dkAj1/.

C270. Thorium utilization program quarterly progress report for the period ending November 30, 1974, GA-A13255, General Atomic Company, San Diego, CA, February 1975. (Scan and upload requested from DOE OSTI.)

C271. Thorium utilization program quarterly progress report for the period ending February 28, 1975, GA-A13366, General Atomic Company, San Diego, CA, May 1975, http://www.osti.gov/energycitations/servlets/purl/4200235-1naqWE/.

C272. Thorium utilization program quarterly progress report for the period ending May 31, 1975, GA-A13510, General Atomic Company, San Diego, CA, August 1975, http://www.osti.gov/ energycitations/servlets/purl/4194677-s203OM/.

C273. Thorium utilization program quarterly progress report for the period ending August 31 1975, GA-A13593, General Atomic Company, San Diego, CA, September 1975, http://www.osti.gov/energycitations/servlets/purl/4139404-RteKXC/.

C274. Thorium utilization program quarterly progress report for the period ending November 30, 1975, GA-A13746, General Atomic Company, San Diego, CA, December 1975. (Scan and upload requested from DOE OSTI.)

C275. Thorium utilization program quarterly progress report for the period ending February 29, 1976, GA-A13833, General Atomic Company, San Diego, CA, March 1976, http://www.osti.gov/energycitations/servlets/purl/7186516-xgsTCM/.

C276. Thorium utilization program quarterly progress report for the period ending May 31, 1976, GA-A13949, General Atomic Company, San Diego, CA, June 1976, http://www.osti.gov/ energycitations/servlets/purl/7344148-4Mm9LE/.

C277. Thorium utilization program quarterly progress report for the period ending August 31, 1976, GA-A14085, General Atomic Company, San Diego, CA, September 1976, http://www.osti.gov/energycitations/servlets/purl/7258106-moiweR/.

C278. Thorium utilization program quarterly progress report for the period ending November 30, 1976, GA-A14214, General Atomic Company, San Diego, CA, December 1976. (Scan and upload requested from DOE OSTI.)

C279. Thorium utilization program quarterly progress report for the period ending February 28 1977, GA-A14304, , General Atomic Company, San Diego, CA, March 1977, http://www.osti.gov/energycitations/servlets/purl/7314364-99V4gW/.

C280. Thorium utilization program quarterly progress report for the period ending May 31, 1977, GA-A14441, General Atomic Company, San Diego, CA, June 1977, http://www.osti.gov/energycitations/servlets/purl/7089550-10AiqY/.

C281. HTGR fuel recycle program quarterly progress report for the period ending August 31, 1977, GA-A14583, General Atomic Company, San Diego, CA, September 1977, http://www.osti.gov/energycitations/servlets/purl/5415940-JrIMyB/.

C282. HTGR fuel recycle program quarterly progress report for the period ending November 30, 1977, GA-A14738, General Atomic Company, San Diego, CA, December 1977. (Scan and upload requested from DOE OSTI.) 
C283. HTGR fuel recycle program quarterly progress report for the period ending February 28, 1978, GA-A14878, General Atomic Company, San Diego, CA, March 1978. (Document not found in DOE-OSTI resources.)

C284. HTGR fuel recycle development program quarterly progress report for the period ending May 31, 1978, GA-A15011, General Atomic Company, San Diego, CA, June 1978, http://www.osti.gov/energycitations/servlets/purl/6893787-scA6OJ/.

C285. HTGR fuel recycle development program quarterly progress report for the period ending August 31, 1978, GA-A15105, General Atomic Company, San Diego, CA, September 1978. (Scan and upload requested from DOE OSTI.)

C286. Consolidated reprocessing program quarterly progress report ending February 28, 1979, GA-A15315, General Atomic Company, San Diego, CA, March 1979, http://www.osti.gov/ energycitations/servlets/purl/6222316-rMddij/.

C287. Consolidated reprocessing program quarterly progress report for the period ending May 31, 1979, GA-A15440, General Atomic Company, San Diego, CA, June 1979, http://www.osti.gov/energycitations/servlets/purl/6117001-wqhVFy/.

C288. L.H. Brooks et al., Spent fuel shipping, reprocessing, and recycle fabrication in the HTGR fuel cycle, Gufl-GA-A12272 (CONF-730918-2), Gulf General Atomic, San Diego, CA, December 1972, http://www.osti.gov/energycitations/servlets/purl/4419225-YpNuyK/.

C289. L.H. Brooks, Progress in the Thorium/U233 shipping-reprocessing,-and refabrication technology, GA-A13064 (CONF-740804-3), General Atomic Company, San Diego, CA, July 1974, http://www.osti.gov/energycitations/servlets/purl/4257798-XkR6YK/.

C290. R.M. Burgoyne and N.D. Holder, HTGR spent fuel storage study, GA-A15262, General Atomic Company, San Diego, CA, April 1979, http://www.osti.gov/energycitations/ servlets/purl/6053019-neUFN9/.

C291. L. Abraham, Reprocessing flowsheet and material balance for MEU spent fuel, GA-A15145, General Atomic Company, San Diego, CA, October 1978, http://www.osti.gov/ energycitations/servlets/purl/6406904-ewOQPo/.

C292. M.H. Merrill and R.K. Lane, MEU/Th fuel cycle optimization for the Lead Plant, GA-A15180, General Atomic Company, San Diego, CA, December 1978, http://www.osti.gov/ energycitations/servlets/purl/6349304-tk6rPA/.

C293. H.W. Wong and L. Abraham, HTGR spent reflector block disposal study, GA-A13860, General Atomic Company, San Diego, CA, May 1976, http://www.osti.gov/energycitations/ servlets/purl/7228317-r5WiLe/.

C294. N.D. Holder et al., Processing of FRG mixed oxide fuel at General Atomic under the US/FRG cooperative agreement for spent fuel elements, GA-A16111 (CONF-801107-37), General Atomic Company, San Diego, CA, November 1980, http://www.osti.gov/energycitations/ servlets/purl/6921670-51sB7O/.

C295. N.D. Holder et al., Processing of FRG High-Temperature Gas-cooled Reactor fuel elements at General Atomic under the US/FRG cooperative agreement for spent fuel elements, GA-A16567 (CONF-811103-62), General Atomic Company, San Diego, CA, November 1981, http://www.osti.gov/energycitations/servlets/purl/5817519-VqBYb8/.

C296. Program Staff, HTGR Spent Fuel Treatment Program: HTGR Spent Fuel Treatment Development Program Plan, GA-A17601, GA Technologies, San Diego, CA, December 1984, http://www.osti.gov/energycitations/servlets/purl/6245055-JWNG3R/. 
C297. N.D. Holder and W.S. Lessig, Advances in HTGR spent fuel treatment technology, GA-A17625 (CONF-840802-7), GA Technologies, San Diego, CA, August 1984, http://www.osti.gov/energycitations/servlets/purl/6900012-Dg1enB/.

C298 P.R. Kasten, L.L. Bennett, and W.E. Thomas, An Evaluation of Plutonium Use in HighTemperature Gas-Cooled Reactors, ORNL-TM-3525, Oak Ridge National Laboratory, Oak Ridge, TN, October 1971, http://www.ornl.gov/info/reports/1971/3445605144279.pdf.

C299. C.F. Sanders and J.D. Sease, Fabrication and characterization of plutonium test element FTE13: an HTGR test element containing $\mathrm{PuO}_{2-x}, \mathrm{Th}_{0.75} \mathrm{Pu}_{0.25} \mathrm{O}_{2-x}$, and $\mathrm{ThO}_{2}$, ORNL/TM-4207, Oak Ridge National Laboratory, Oak Ridge, TN, August 1, 1973.

C300. T.N. Tiegs, "Irradiation performance of Pu-containing coated-particle fuels," Transactions of the American Nuclear Society 28 (American Nuclear Society Annual Meeting, 18 June 1978, San Diego, CA, CONF-780622), June 1, 1978.

C301. Unpublished report transmitted to GA: T.N. Tiegs, Postirradiation Examination of PlutoniumContaining Coated Particle Fuel in Peach Bottom Test Element FTE-13, Oak Ridge National Laboratory, Oak Ridge, TN, September 15, 1978. (Reproduced copies of this report and cover letter are available from ORNL staff but the original copy of the report has been lost)

C302. T.N. Tiegs, Fission product Pd-SiC interaction in irradiated coated particle fuels, ORNL/ TM-7203, Oak Ridge National Laboratory, Oak Ridge, TN, April 1, 1980, http://www.ornl.gov/info/reports/1980/3445604492289.pdf.

C303. J.J. Saurwein et al., Peach Bottom test element program-Final report, GA-A15999, GA Technologies, Inc., San Diego, CA, November 1, 1982, http://www.osti.gov/energycitations/servlets/purl/6347913-d1JgQI/.

C304. Mitsuru Maeda and Eiji Yagi, Feasibility Study for Removal of SiC Coating in HTGR-type Fuel by $F_{2}$-Fluorination, JAERI-M-7060, Japan Atomic Energy Research Institute, Tokai, Japan, April 1977, http://jolissrch-inter.tokai-sc.jaea.go.jp/pdfdata/JAERI-M-7060.pdf.

C305. M.A. Fütterer, H. Bluhm, P. Hoppé, and J. Singer, Head-End Process for the Reprocessing of Reactor Core Material, International Patent WO/2006/087360, European Patent EP1849164, publication date 24 August 2006, http://www.wipo.int/pctdb/en/wo.jsp?wo=2006087360.

C306. Jacques Paris and Jean-Raymond Costes (Commissariat a I'Energie Atomique), Process for the Treatment of Nuclear Graphite Contaminated with Radioelements by Milling the Said Graphite in a Liquid Medium, United States Patent US 7,500,623 B2, March 10, 2009, http://patft.uspto.gov/netacgi/nph-

Parser?Sect $1=$ PTO1\&Sect $2=$ HITOFF $\& d=P A L L \& p=1 \& u=\% 2 F n e t a h t m 1 \% 2 F P T O \% 2 F s r c h n u m$. $\mathrm{htm} \& \mathrm{r}=1 \& \mathrm{f}=\mathrm{G} \& \mathrm{l}=50 \& \mathrm{~s} 1=7500623 . \mathrm{PN} . \& \mathrm{OS}=\mathrm{PN} / 7500623 \& \mathrm{RS}=\mathrm{PN} / 7500623$. 